\title{
Comparative effectiveness of natural and synthetic bone grafts in oral and maxillofacial surgery prior to insertion of dental implants: Systematic review and network meta-analysis of parallel and cluster randomized controlled trials
}

Papageorgiou, Spyridon N ; Papageorgiou, Panagiotis N ; Deschner, James ; Götz, Werner

\begin{abstract}
OBJECTIVES Bone grafts are often used to enhance bone volume/quality prior to implantation insertion. This systematic review compares the histomorphometric effectiveness of bone grafts in an evidence-based manner. DATA Randomized clinical trials comparing histomorphometrically the $\%$ of newly-formed bone between two grafts were included. Risk of bias within and across studies was assessed with the Cochrane tool and the GRADE approach, respectively. Random-effects pairwise meta-analyses were conducted, followed by network meta-analysis, network meta-regression and sensitivity analyses. SOURCES Four electronic databases were searched from inception to June 2015 without limitations. STUDY SELECTION A total of 12 trials (5 parallel; 7 cluster) with a total of 231 patients (302 grafted sites) were included. No statistically significant differences were found in the $\%$ of new bone from pairwise comparisons between any two bone grafts. Treatment ranking based on the evidence network indicated that autografts presented the highest percentage of new bone, followed by synthetic grafts, xenografts, and allografts. No differences according to patient age, sex, healing time, membrane used or kind of surgical graft use were identified. Our confidence on pairwise comparisons was moderate to very low due to study limitations, inconsistency, and imprecision; our confidence on graft ranking was moderate due to study limitations. CONCLUSIONS No significant differences were found in the percentage of new bone between any two grafts. CLINICAL SIGNIFICANCE Synthetic bone substitutes or xenologous bone grafts can be used as an alternative to autologous graft in order to overcome problems of additional surgeries or limited graft availability.
\end{abstract}

DOI: https://doi.org/10.1016/j.jdent.2016.03.010

Posted at the Zurich Open Repository and Archive, University of Zurich

ZORA URL: https://doi.org/10.5167/uzh-133040

Journal Article

Accepted Version

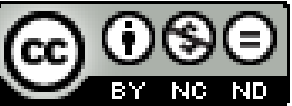

The following work is licensed under a Creative Commons: Attribution-NonCommercial-NoDerivatives 4.0 International (CC BY-NC-ND 4.0) License.

Originally published at:

Papageorgiou, Spyridon N; Papageorgiou, Panagiotis N; Deschner, James; Götz, Werner (2016). Comparative effectiveness of natural and synthetic bone grafts in oral and maxillofacial surgery prior to insertion 
of dental implants: Systematic review and network meta-analysis of parallel and cluster randomized controlled trials. Journal of Dentistry, 48:1-8.

DOI: https://doi.org/10.1016/j.jdent.2016.03.010 
Title Page

Comparative effectiveness of natural and synthetic bone grafts in oral and maxillofacial surgery prior to insertion of dental implants: systematic review and network meta-analysis of parallel and cluster randomized controlled trials

\section{Spyridon N. Papageorgiou ${ }^{1,2}$, Panagiotis N. Papageorgiou ${ }^{3}$, James Deschner ${ }^{4}$, and Werner Götz ${ }^{1}$}

${ }^{1}$ Department of Orthodontics, School of Dentistry, University of Bonn, Bonn 53111, Germany

${ }^{2}$ Department of Oral Technology, School of Dentistry, University of Bonn, Bonn 53111, Germany

${ }^{3}$ Department of Neurosurgery, Queen Elizabeth University Hospital, Glasgow G51 4TF, UK

${ }^{4}$ Section for Experimental Dento-Maxillo-Facial Medicine, School of Dentistry, University of Bonn, Bonn 53111, Germany

Short title: Bone grafts in maxillofacial surgery

\section{Corresponding Author:}

Spyridon N. Papageorgiou, Department of Orthodontics, School of Dentistry, University of Bonn, Welschnonnenstr. 17, 53111, Bonn, Germany. Tel.: +49-(0)228-287-22449; Fax: +49-(0) 228-287-22588; E-mail: snpapage@gmail.com.

Abstract word count: 250

Total word count: 3789

Total number of tables/figures: 6

Number of references: 48

Keywords: bone grafting; bone substitutes; alveolar ridge augmentation; tooth extraction; sinus floor augmentation; systematic review; network meta-analysis; randomized controlled trial 


\section{A B S T R A C T}

Objectives: Bone grafts are often used to enhance bone volume / quality prior to implantation insertion. This systematic review compares the histomorphometric effectiveness of bone grafts in an evidencebased manner.

Data: Randomized clinical trials comparing histomorphometrically the \% of newly-formed bone between two grafts were included. Risk of bias within and across studies was assessed with the Cochrane tool and the GRADE approach, respectively. Random-effects pairwise meta-analyses were conducted, followed by network meta-analysis, network meta-regression and sensitivity analyses.

Sources: Four electronic databases were searched from inception to June 2015 without limitations. Study selection: A total of 12 trials (5 parallel; 7 cluster) with a total of 231 patients (302 grafted sites) were included. No statistically significant differences were found in the $\%$ of new bone from pairwise comparisons between any two bone grafts. Treatment ranking based on the evidence network indicated that autografts presented the highest $\%$ of new bone, followed by synthetic grafts, xenografts, and allografts. No differences according to patient age, sex, healing time, membrane used or kind of surgical graft use were identified. Our confidence on pairwise comparisons was moderate to very low, due to study limitations, inconsistency, and imprecision; our confidence on graft ranking was moderate, due to study limitations.

Conclusions: No significant differences were found in the $\%$ of new bone between any two grafts.

Clinical significance: Synthetic bone substitutes or xenologous bone grafts can be used as an alternative to autologous graft, in order to overcome problems of additional surgeries or limited graft availability. 


\section{Manuscript}

\section{Introduction}

\subsection{Background}

Resorption of the edentulous or partially edentulous alveolar ridge frequently compromises dental implant placement in a prosthetically ideal position. Therefore, augmentation of an insufficient bone volume is often indicated prior to or in conjunction with implant placement to attain predictable longterm functioning and an esthetic treatment outcome. Autogenous bone grafts (AUTs) are considered the gold standard in bone regeneration procedures [1]. However, donor site morbidity, transmission of live viruses, unpredictable resorption, limited quantities available, and the need to include additional surgical sites are autografts-related drawbacks that have intensified the search for suitable alternatives [2].

Bone-substitute materials have increased in popularity as adjuncts to or replacements for AUTs in bone augmentation procedures to overcome many of their limitations [3]. Bone-substitute materials can be categorized in three groups: (1) allogenic grafts (ALLs), from another individual within the same species; (2) xenogenic grafts (XENs), from another species; or (3) alloplastic, synthetically produced grafts (SYNs). According to contemporary trends, the ideal characteristics of a bone-substitute material include space maintenance, pre-specification of the desired anatomical form, support to the periosteum, acceleration of bone remodeling, osteoconductive guidance, carrier function for antibiotics, growth factors or gene therapy approaches or scaffolds for tissue engineering [2,4-6]. It may be too optimistic to expect that a single grafting material fulfill all these functions and will be suitable for all indications.

A large number of systematic reviews with meta-analyses has been published in the last five years [7-15], but most were of suboptimal conduct or reporting and / or had methodological limitations [16], while none performed network meta-analysis to compare directly all existing bone graft alternatives.

\subsection{Objective}

We conducted a systematic review of parallel and cluster randomized trials (RCTs) including network meta-analysis in order to investigate the comparative effectiveness of bone grafts used in oral and 
maxillofacial surgery prior to implant placement in humans and to compare all grafts with the current gold standard (AUT).

\section{Materials and Methods}

\subsection{Protocol and registration}

The protocol for this review was made a priori based on the PRISMA-P statement [17], registered in PROSPERO (CRD42015023467), and all post hoc changes were noted. This systematic review was conducted according to Cochrane Handbook [18] and reported according to the newly-published PRISMA Extension for network meta-analyses [19].

\subsection{Eligibility criteria and literature search}

RCTs on human patients comparing any two natural or synthetic bone grafts were included. No lumping of interventions was performed during the study selection phase. Non-RCTs were excluded, due to bias [20-23]. Both parallel (one graft per patient) and clustered trials (>one graft per patient) were included and assessed appropriately together, by calculating for the latter clustering-adjusted estimates through random-effects regression. The pre-specified eligibiligy criteria can be found in Appendix 1.

Four electronic databases were searched systematically by one author (SNP) without any limitations from inception up to June $15^{\text {th }}, 2015$ and re-checked in October 2015 for manual additions (Appendix 1). Four additional sources (Scopus, Google Scholar, ClinicalTrials.gov, and ISRCTN registry) were manually searched for additions. Authors contacted for missing data were asked about additional missed trials. No search limitations concerning language, publication year or status were applied, except for studies on humans, where available. The reference/citation lists of the included trials and relevant systematic reviews were manually searched as well.

\subsection{Study selection}

Titles identified were screened by one author (SNP) with a subsequent duplicate independent checking of their abstracts/full-texts against the eligibility criteria by two authors (SNP, PNP), while conflicts were resolved by a third author (JD).

\subsection{Data collection}


Characteristics of included trials and numerical data were extracted in triplicate by three authors (SNP, PNP, JD) using a priori constructed and piloted extraction forms. Lumping of identified grafts was performed into four categories: AUT, ALL, SYN, and XEN. In case of combinations of grafts, the graft was categorized according to the graft with over 70\% contribution (Appendix 1). Piloting of the forms was performed during the protocol stage until over 90\% agreement was reached. Missing or unclear information was requested per e-mail by the trials' authors.

\subsection{Risk of bias in individual trials}

The risk of bias of the included trials was assessed using Cochrane's risk of bias tool [18] after initial calibration by three review authors (SNP, PNP, JD) and any disagreement was discussed with a fourth author (WG). The risk of bias assessment for each trial was based on the primary outcome (\% new bone) or, if this was not included in the trial, on the trial's primary outcome. The risk of bias was incorporated in data synthesis using the framework of Salanti et al. [24].

\subsection{Data synthesis}

As the outcome of bone augmentation could be influenced by the bone graft, the technique, the patient's individual biological response, and post-operative management, a random-effects model according to DerSimonian and Laird was deemed appropriate to incorporate this variability [25]. Both pairwise and network meta-analyses were conducted to obtain estimates for primary and secondary outcomes, and presented as Mean Differences (MDs) or Relative Risks (RRs) with 95\% Confidence Intervals (CIs). Heterogeneity was conventionally assessed with tau ${ }^{2}$ and $\mathrm{I}^{2}$ (Appendix 2) and 95\% Prediction Intervals (PrIs) were calculated to predict effects in a future clinical setting by incorporating heterogeneity. For clustered trials, the raw data were requested from the trial's authors and clustering-adjusted estimates were calculated with univariable and multivariable regression.

The results of all direct and mixed comparisons were presented in league tables and forest plots. The latter were augmented with contours of effect magnitude based on multiples of the mean standard deviation of the included outcome (10\%): 0-10\% - clinically-irrelevant effect, 10\%-20\% - moderate effect, 20\%-30\% - large effect, and $>30 \%$ - very large effect. In order to rank treatments for an outcome, the Surface Under the Cumulative RAnking (SUCRA) probabilities were used, which express as a percentage the effectiveness of every intervention relative to an imaginary intervention that is always the best 
without uncertainty $[26,27]$. Thus, large SUCRA scores indicate a more effective intervention. All analyses were done with Stata version 13 (StataCorp, College Station, TX) by one author (SNP), with the commands xtgee, metan, mvmeta, network and the routines from Chaimani et al. [28]. A two-tailed P-value of 0.05 was considered significant for hypothesis-testing.

The following pre-specified effect modifiers were checked as possible sources of inconsistency / heterogeneity at patient or study level with conventional methods (Appendix 2): (a) characteristics of patients (age, gender), (b) type of graft, (c) surgical procedure conducted, (d) use of membrane, (e) membrane type, and (f) healing time.

\subsection{Risk of bias across studies}

The overall quality of clinical recommendations (confidence in effect estimates) for each of the main outcomes and for the network was rated using the Grades of Recommendation, Assessment, Development, and Evaluation (GRADE) approach, based on the proposal of Salanti et al. [24]. For this assessment, the risk of bias of each included trial was re-assessed separately at outcome level. The GRADE assessment was performed by one author (SNP) and discussed with the rest (PNP, JD, WG).

\subsection{Additional analyses}

Signs of publication bias were planned to be assessed, if ten or more included studies contributed to an outcome, with a 'comparison-adjusted' funnel plot together with an accompanying statistical test [28]; this was not performed, as no appropriate treatment ordering by bias-related factors was possible. Smallstudy effects were assessed by network meta-regression according to trial size (effect variance).

Sensitivity analyses were conducted (i) by attempting to form an alternate network geometry and to compare its results, (ii) comparing the design-by-treatment model to the original analysis, and (iii) examining the basic design of the included studies and its influence.

\section{Results}

\subsection{Study selection}

The systematic electronic and manual search identified 283 and 7 reports, respectively (Fig 1). From these a total of 104 and 167 reports were excluded through screening and fulltext assessment, 
respectively (Appendix 3). Finally, a total of 45 papers (pertaining to 41 unique trials) were included in the systematic review.

\subsection{Study characteristics}

The characteristics of the trials included in the qualitative part of this study (i.e. systematic review) can be seen in Appendices 4-6. From the 41 included trials 6 (15\%) were multicenter and 37 (90\%) took place in a university environment from 15 different countries. A total of 852 patients (47\% male and 53\% female) were included with an average of 20.8 patients per trial and an average age of 50.6 years. From the included trials, 17 (41\%) were of parallel design and 24 (59\%) of clustered design (i.e. more than one grafted site per patient).

As far as surgical procedures were concerned, 54\% of the trials assessed sinus lift, 32\% preservation of extraction sockets, $12 \%$ ridge augmentation, and the last $2 \%$ both ridge augmentation and sinus lift with a total of 1164 surgical sites being grafted. A wide variety of bone grafts were used, which were categorized as AUT (harvested mostly intraorally or from the iliac crest), ALL, SYN (based on hydroxyapatite or calcium sulphate), and XEN (mostly represented by Bio-Oss; Geistlich, Wolhusen, Switzerland). The grafted region was covered additionally by a membrane (mostly collagen ones) in $56 \%$ of the trials, by a collagen sponge or fibrin glue in $4 \%$ of the trials or without additional means in $37 \%$ of the trials.

In all trials that assessed histomorphometrically the grafted regions, bone samples were collected after a healing phase of 3-9 months during a subsequent implant insertion. Among the 25 out of 41 included trials that adequately reported the subsequent implant insertion, a total of 1261 implants were inserted (mean of 50.4 implants per study).

\subsection{Risk of bias within studies}

The risk of bias assessment for the 41 included trials can be seen in Appendices 7-9. High risk of bias arising from problematic generation of the random sequence was seen in $10 \%$ of the trials, bias from incomplete outcome data in $7 \%$ of the trials, and bias from selective outcome reporting in $5 \%$ of the trials. The main source of bias however, was residual bias due to other reasons, including poor trial design, inadequate data handling for cluster trials or failing to take into account confounding introduced from smoking or systemic diseases. It is however important, that extreme uncertainty exists on the bias 
assessment of random sequence generation, allocation concealment and blinding, as these were very poorly reported, making a formal assessment of their appropriateness impossible ("unclear" categories in the risk of bias summary).

\subsection{Results of individual trials}

The results of the 41 individual trials that were included in the systematic review are expressed as MDs or RRs in Appendix 10. In the case of available individual patient data, these are based on univariable or multivariable generalized estimating equations accounting for clustering within patients and any possible confounders reported in the original trial (patient sex, age, healing time, membrane type).

\subsection{Network structure and synthesis of results}

Out of the 41 trials included in the qualitative part of this study (i.e. systematic review), only 12 were included in the quantitative synthesis (i.e. meta-analyses) for various reasons (Fig 1). These pertained to 5 pairwise comparisons (AUT vs ALL, AUT vs SYN, AUT vs XEN, ALL vs SYN, and SYN vs XEN), with most of them being statistically insignificant, although high heterogeneity was found (Table 1; Appendix 11).

When assessing all comparisons for the primary outcome of the review (\% of new bone) at the same time, a square network of 12 trials, 231 patients and 302 grafted sites was formed (Fig 2). This network included the 5 above-mentioned direct comparisons, 1 indirect comparison (ALL vs XEN), and additional mixed-treatment information from the whole network (Appendix 12). The assumption of transitivity was satisfied on theoretical grounds, as all trials randomized adult patients of similar age and sex, and with similar medical background, as the primary outcome measurement pre-included the ability to subsequently insert a dental implant. No major violation of transitivity was identified on practical ground, as mean ages and the \% of sex distribution was relatively similar among all comparisons (Appendix 13). The results for all comparisons arising from direct comparisons and from the evidence network can be seen in Fig 3 and Appendix 14. All other grafts resulted in lower \% of new bone compared to AUT, while both SYN and XEN resulted in higher \% of new bone compared to ALL. Finally, SYN resulted in slightly higher \% of new bone compared to XEN, although high heterogeneity existed (tau ${ }^{2}$ of 141.37 ) and all abovementioned comparisons were statistically non-significant, due to small sample size and wide $95 \%$ CIs. The ranking of the various grafts according to the $\%$ of new bone formed is found in Fig 4 . As can be seen from the SUCRA plots, AUT had the best results, followed by SYN, XEN, and finally ALL. 


\subsection{Exploration of inconsistency}

When inconsistency was checked in a loop-specific approach (Appendix 15), one of the two existing closed triangular was inconsistent. Additionally, comparison of direct and indirect estimates (nodesplitting procedure) indicated considerable differences for four out of five comparisons, which were almost statistically significant at $5 \%$, despite the very wide confidence intervals, due to the limited number of trials (Appendix 16). Data were double-checked and we could not identify any important variable that differed across comparisons/loops. However, the number of included studies in all loops was typically small, so the extent of inconsistency was not deemed substantial enough. Additionally, the comparison of the original analysis (consistency model) with the inconsistency model yielded similar results (Appendix 17).

\subsection{Risk of bias across studies}

Our confidence in the evidence according to the GRADE approach can be found in Table 2 and Appendix 18-19. As can be seen, our confidence in pairwise comparisons was moderate to very low, mainly due to study limitations, inconsistency, and imprecision. On the other side, confidence in the overall ranking of treatments was found to be moderate, due to inherent limitations of the included studies.

\subsection{Additional analyses (alternate geometry, subgroup analysis, meta-regression)}

As an additional analysis, we attempted to construct an alternative geometry network by analyzing all commercially available SYNs separately (Appendix 20). This resulted however in a markedly inconsistent network with sparse connections, which made inferences about the network's transitivity and coherence void. Under this alternate treatment ranking (Appendix 21), AUT was the worst graft in terms of $\%$ of new bone, which is highly improbable based on direct estimates. Therefore, the analysis of this alternate network geometry was discarded as instable.

The effect of the various confounding covariates (patient sex, patient age, type of membrane, and healing time) from individual patient data can be seen in Appendix 22. After calculating the effect of each covariate on the primary outcome within-trials from raw data, and pooling across-trials, no significant modifying effect could be found $(\mathrm{P}>0.05)$. The single exception was the type of membrane used over the 
graft, where the expanded polytetrafluoroethylene membrane was associated with lower \% of new bone compared to the acellular dermal matrix allograft membrane $(\mathrm{P}=0.040)$.

Network meta-regression was undertaken in order to address the impact of possible confounders on the network in a universal scale. As can be seen in Appendix 17, the model fit was not influenced by surgery type (socket preservetation, sinus lift or combination procedures), but was affected by the use of membranes over the grafts. However, treatment rankings based on the original analysis or on analysis adjusting for use of membrane (or not) for the primary and secondary outcomes studied were almost exactly the same. The slight variation in the treatment ranking regarding $\%$ of new bone was discarded as non-credible, as it contradicted with direct evidence of AUT's superiority, and therefore, the modifying effect of membrane use was deemed insignificant.

\subsection{Secondary outcomes}

A large number of outcomes were reported from the included studies (Appendix 10), which are however only briefly discussed, as they did not refer to histomorphometry and therefore were not the main focus of this review.

As far as secondary histomorphometry outcomes are concerned, many trials also reported the \% residual graft particles and the $\%$ connective tissue from the samples harvested prior to implant insertion (Appendix 23). The evidence network and the contribution plots (Appendices 24-25) for these two outcomes was similar to the network for the primary outcome ( $\%$ of new bone). Both networks for the $\%$ residual graft particles and the $\%$ connective tissue presented considerable heterogeneity $\left(\operatorname{tau}^{2}\right.$ of 106.30 and 73.62), respectively. AUT and XEN were ranked as equally probable to be the best grafts in terms of having the least \% of residual graft particles, while AUT and ALL were equally probable to be the be in terms of \% of connective tissue (Appendix 26). However, the ranking in places 2-3 was SYN-ALL and XENSYN for $\%$ of residual graft and $\%$ of connective tissue, respectively. When the primary outcome of $\%$ new bone and the secondary outcome of \% residual graft were taken into account at the same time in a clustered ranking plot (Appendix 27), AUT was the best graft, while SYN and XEN were relatively comparable in terms of effectiveness, and ALL was the worst. Finally, node-splitting analysis regarding these two secondary outcomes (Appendix 28) did not identify any serious threats to consistency, although wide confidence intervals were present. 


\section{Discussion}

\subsection{Summary of evidence}

This systematic review assessed in an evidence-based matter the histomorphometric effects of various bone grafts in sinus lift, extraction socket preservation, and ridge augmentation in human patients prior to the insertion of dental implants. Using a network meta-analysis approach, no statistically significant differences could be found for most of the histomorphometric outcomes, although this was probably due to few included studies and subsequently wide CIs. Based on the evidence network, it could be shown that AUTs is the gold standard both in terms of new bone formation and graft integration, which agrees with existing knowledge [1]. The same clear distinction could be made for ALL, which was the worst graft family studied for both bone formation and graft resorption. As far as SYN and XEN are concerned, they formed an intermediate category, where SYN was associated with higher bone formation and lower graft resorption, while the opposite was found for XEN.

SYNs used in oral and maxillofacial surgery have been reported to be bioabsorbable and nontoxic [29] with a chemical structure similar to bone mineral composition. Previous studies have reported that osteoclast-like cells (or foreign body giant cells [30]) can be observed both along the surface of newly-formed bone and directly on the graft granules during the healing phase [31-35]. Additionally, certain SYNs (bioactive glasses) have been reported to become coated by a calcium-phospate layer in vivo and to form a direct chemical bond to bone [29]. Certain modern XENs in the nanometer range like Ostim (Heraeus Kulzer GmbH, Hanau, Germany) or NanoBone (Artoss GmbH, Rostock Germany) might also lead to a significant increase in contact surface area and thereby result in augmented new bone regeneration $[36,37]$. The single identified trial however, that directly compared Ostim to another SYN (SINTLife, FinCeramica, Faenza, Italy) did not find considerable differences [38]. Based on this network metaanalysis, SYN was the second best graft in terms of $\%$ new bone, which was about 5.5\% lower than AUT, 4.9\% higher than XEN, and 8.0\% higher than ALL.

XENs, and its most widely known commercial product Bio-Oss (Geistlich Pharma AG, Wolhusen, Switzerland), have been successfully used in several studies to preserve ridge dimensions following tooth extraction [34,39] and have been proven biocompatible and osteoconductive [40], as their structure and surface area promote capillary ingrowth and migration and proliferation of osteoblasts [41,42]. On the other hand, some studies have reported delayed healing regions grafted with XEN [42,43]. In the present analysis, XENs were the closely tied to the first or second best place after AUTs, with slightly lower $\%$ of 
new bone $(-4.9 \%)$ and slightly higher $\%$ of resorption of graft particles $(+2.3 \%)$ than SYNs, which indicated acceptable biocompatibility and effectiveness.

Both osteoinductive and osteoconductive properties [44,45], as well as the preservation of bone morphogenetic proteins [46] have been attributed to ALLs used in oral surgery. However, a higher percentage of residual graft particles and less new bone formation in ALL-graft bone biopsies compared to other grafts has also been reported [47], which agrees with our results. ALL was the least effective graft than all other, which combined with the lack of osteogenic properties [48], and the risk of transmission of infectious agents, malignancies, systemic disorders (autoimmune disease), or toxins [2] render them a less appealing alternative to bone grafting. In the present analysis ALLs were the worst graft in terms of \% new bone, which was $13.5 \%$ lower than AUT, 8.0\% lower than SYN, and 3\% lower than XEN.

\subsection{Strengths and limitations}

This systematic review has several strengths, including the a priori registration of its protocol, unrestricted literature search, attempts to maximize data output through communication with trial authors (Appendix 29), triplicate review procedures with reporting of any deviations from protocol (Appendix 30), use of individual patient data (where applicable), adjustment of effect estimates for confounders through multivariable regression, simultaneous synthesis of all available evidence by network meta-analysis, and formal assessment of our confidence in the overall quality of evidence with the GRADE approach.

However, several limitations also exist. First of all, only some of the data requests were answered from trialists, leading certain cluster-trials to be excluded due to incomplete reporting. Additionally, the reporting completeness of many identified trials was problematic, which precluded robust assessment of the risk of bias. Furthermore, the limited number of trials included in each combination of nodes makes difficult to robustly evaluate the transitivity and consistency of the network. The network could have been broken down to include all commercially-available grafts separately (Appendix 20), but this was problematic, due to the scarcity of most comparisons. Alternatively, partially-available individual patient data could have been combined with aggregate data within a Bayesian framework to increase precision [49] or a three-level hierarchical level Bayesian analysis could have been used to test across classes and subclasses of grafts simultaneously [50]. The test for inconsistency and the meta-regressions were likewise affected by this scarcity of trial and their large sampling errors due to small samples, as was seen 
by their wide confidence intervals. Additionally, the use of a Bayesian framework with an informative prior could alleviate some of the high heterogeneity/imprecision of the network. Therefore, caution is warranted by the interpretation of these tests, as lack of power and the subsequent imprecision might "mask" an existing effect. Finally, for most trials the risk of bias was either unclear or high.

The findings of this review could be generalizable to most systematically healthy patients, where bone grafting is needed for a surgical procedure (sinus lift, preservation of an extraction socket or ridge augmentation) prior to implant placement. Although smokers were not excluded, this was deemed as a factor that could possibly introduce bias, due to impaired wound healing [51]. The results of this review might not be applicable to patients receiving bone grafting simultaneously with implant placement or bone grafting of periodontal defects. However, taking into account the abovementioned limitations, the generalizability of this review's findings should be viewed with caution.

\subsection{Conclusions}

According to mixed comparisons from randomized controlled trials of bone grafting in humans prior to implant insertion, no statistically significant differences could be found for any of the pairwise comparisons, although our confidence in these estimates is moderate to very low, mainly due to study limitations, inconsistency, and imprecision.

According to the ranking of available grafts based on the evidence network (moderate confidence):

- Autologous grafts presented the highest \% of newly-formed bone, followed by synthetic grafts, xenologous grafts, and allogeneic grafts.

- Autologous grafts presented the lowest $\%$ of residual graft particles, followed by xenologous grafts, synthetic grafts, and allogeneic grafts.

- Autologous grafts presented the lowest \% of connective tissue, followed by allogeneic grafts, xenologous grafts, and synthetic grafts.

\subsection{Recommendations for clinical practice}

Taking into account the extra burden of an additional surgery of the gold standard (autologous grafts) and the suboptimal performance of allogeneic grafts, synthetic or xenologous bone grafts can be considered as an alternative. Synthetic bone grafts are associated with increased bone formation, but 
lower graft resorption compared to xenologous bone grafts. However, these recommendations should be viewed with caution, due to the limitations of the present study.

\subsection{Recommendations for further research}

Existing evidence is based on limited trials of small samples with unclear reporting of design characteristics. Researchers are encouraged to conduct additional adequately powered randomized trials with clear reporting based on the CONSORT statement [52]. As far as consolidation of the evidence network is concerned, trials comparing different synthetic bone substitutes with autologous or xenologous bone grafts are needed, in order to enable ranking of the separate commercially-available grafts.

\section{Conflicts of interest}

No funding existed for this study. All authors report no real or perceived conflict of interest. 


\section{References}

1. Klijn RJ, Meijer GJ, Bronkhorst EM, Jansen JA. A meta-analysis of histomorphometric results and graft healing time of various biomaterials compared to autologous bone used as sinus floor augmentation material in humans. Tissue Engineering Part B Reviews 2010;16:493-507.

2. Kolk A, Handschel J, Drescher W, Rothamel D, Kloss F, Blessmann M, et al. Current trends and future perspectives of bone substitute materials - from space holders to innovative biomaterials. Journal of Cranio-Maxillo-Facial Surgery 2012;40:706-718.

3. Hallman M, Thor A. Bone substitutes and growth factors as an alternative/complement to autogenous bone for grafting in implant dentistry. Periodontology 2000 2008;47:172-92.

4. Smeets R, Maciejewski O, Gerressen M, Spiekermann H, Hanisch O, Riediger D, et al. Impact of rhBMP2 on regeneration of buccal alveolar defects during the osseointegration of transgingival inserted implants. Oral Surgery, Oral Medicine, Oral Pathology, Oral Radiology, and Endodontology 2009;108:e3-12.

5. Fischer J, Kolk A, Wolfart S, Pautke C, Warnke PH, Plank C, Smeets R. Future of local bone regeneration - Protein versus gene therapy. Journal of Cranio-Maxillo-Facial Surgery 2011;39:54-64.

6. Naujoks C, Langenbach F, Berr K, Depprich R, Kubler N, Meyer U, et al. Biocompatibility of osteogenic predifferentiated human cord blood stem cells with biomaterials and the influence of the biomaterial on the process of differentiation. Journal of Biomaterials Applications 2011;25:497-512.

7. Esposito M, Grusovin MG, Rees J, Karasoulos D, Felice P, Alissa R, et al. Interventions for replacing missing teeth: augmentation procedures of the maxillary sinus. Cochrane Database of Systematic Reviews 2010;3:CD008397.

8. Klijn RJ, Meijer GJ, Bronkhorst EM, Jansen JA. Sinus floor augmentation surgery using autologous bone grafts from various donor sites: a meta-analysis of the total bone volume. Tissue Engineering Part $B$ Reviews 2010;16:295-303.

9. Bae JH, Kim YK, Myung SK. Effects of platelet-rich plasma on sinus bone graft: meta-analysis. Journal of Periodontology 2011;82:660-667.

10. Guo J, Li C, Zhang Q, Wu G, Deacon SA, Chen J, Hu H, et al. Secondary bone grafting for alveolar cleft in children with cleft lip or cleft lip and palate. Cochrane Database of Systematic Reviews 2011;6:CD008050. 
11. Cabezas-Mojón J, Barona-Dorado C, Gómez-Moreno G, Fernández-Cáliz F, Martínez-González JM. Meta-analytic study of implant survival following sinus augmentation. Medicina Oral Patologia Oral y Cirugia Bucal 2012;17:e135-e149.

12. Al-Nawas B, Schiegnitz E. Augmentation procedures using bone substitute materials or autogenous bone - a systematic review and meta-analysis. European Journal of Oral Implantology 2014;7 Suppl 2:S219-S234.

13. Avila-Ortiz G, Elangovan S, Kramer KW, Blanchette D, Dawson DV. Effect of alveolar ridge preservation after tooth extraction: a systematic review and meta-analysis. Journal of Dental Research 2014;93:950-958.

14. Chen ST, Buser D. Esthetic outcomes following immediate and early implant placement in the anterior maxilla--a systematic review. The International Journal of Oral \& Maxillofacial Implants 2014;29 Suppl:186-215.

15. Esposito M, Felice P, Worthington HV. Interventions for replacing missing teeth: augmentation procedures of the maxillary sinus. Cochrane Database of Systematic Reviews 2014;5:CD008397.

16. Papageorgiou SN. Meta-analysis for orthodontists: Part II--Is all that glitters gold? Journal of Orthodontics 2014;41:327-336.

17. Shamseer L, Moher D, Clarke M, Ghersi D, Liberati A, Petticrew M, et al. Preferred Reporting Items for Systematic Review and Meta-Analysis Protocols (PRISMA-P) 2015: elaboration and explanation. British Medical Journal 2015;349:g7647.

18. Higgins JPT, Green S, editors. Cochrane Handbook for Systematic Reviews of Interventions. Version 5.10 (updated March 2011). The Cochrane Collaboration; 2011.

19. Hutton B, Salanti G, Caldwell DM, Chaimani A, Schmid CH, Cameron C, et al. The PRISMA extension statement for reporting of systematic reviews incorporating network meta-analyses of health care interventions: checklist and explanations. Annals of Internal Medicine 2015;162:777-784.

20. Papageorgiou SN, Antonoglou GN, Tsiranidou E, Jepsen S, Jäger A. Bias and small-study effects influence treatment effect estimates: a meta-epidemiological study in oral medicine. Journal of Clinical Epidemiology 2014;67:984-992.

21. Papageorgiou SN, Kloukos D, Petridis H, Pandis N. Publication of statistically significant research findings in prosthodontics \& implant dentistry in the context of other dental specialties. Journal of Dentistry 2015;43:1195-1202. 
22. Koletsi D, Spineli LM, Lempesi E, Pandis N. Risk of bias and magnitude of effect in orthodontic randomized controlled trials: a meta-epidemiological review. European Journal of Orthodontics 2015. [epub ahead of print Jul 14, 2015].

23. Papageorgiou SN, Xavier GM, Cobourne MT. Basic study design influences the results of orthodontic clinical investigations. Journal of Clinical Epidemiology 2015;68:1512-1522.

24. Salanti G, Del Giovane C, Chaimani A, Caldwell DM, Higgins JP. Evaluating the quality of evidence from a network meta-analysis. PLoS One 2014;9:e99682.

25. Papageorgiou SN. Meta-analysis for orthodontists: Part I--How to choose effect measure and statistical model. Journal of Orthodontics 2014;41:317-326.

26. Salanti G, Ades A, Ioannidis J. Graphical methods and numerical summaries for presenting results from multiple-treatment meta-analysis: an overview and tutorial. Journal of Clinical Epidemiology 2011;64:163-171.

27. Mavridis D, Giannatsi M, Cipriani A, Salanti G. A primer on network meta-analysis with emphasis on mental health. Evidence Based Mental Health 2015;18:40-6.

28. Chaimani A, Higgins JP, Mavridis D, Spyridonos P, Salanti G. Graphical tools for network meta-analysis in STATA. PLoS One 2013;8:e76654.

29. Chen Q, Zhu C, Thouas GA. Progress and challenges in biomaterials used for bone tissue engineering: bioactive glasses and elastomeric composites. Progress in Biomaterials 2012;1:2.

30. Lorenz J, Kubesch A, Korzinskas T, Barbeck M, Landes C, Sader R, et al. TRAP-positive multinucleated giant cells are foreign body giant cells rather than osteoclasts: Results from a split-mouth study in humans. Journal of Oral Implantology 2015;41:e257-e266.

31. Gerber T, Holzhüter G, Götz W, Bienengräber V, Henkel KO, Rumpel E. Nanostructuring of biomaterials - a pathway to bone grafting substitute. European Journal of Trauma 2006;32:132-140.

32. Rumpel E, Wolf E, Kauschke E, Bienengräber V, Bayerlein T, Gedrange T, et al. The biodegradation of hydroxyapatite bone graft substitutes in vivo. Folia Morphologica 2006;65:43-48.

33. Götz W, Gerber T, Michel B, Lossdörfer S, Henkel KO, Heinemann F. Immunohistochemical characterization of nanocrystalline hydroxyapatite silica gel (NanoBone(r)) osteogenesis: a study on biopsies from human jaws. Clinical Oral Implants Research 2008;19:1016-1026.

34. Araújo MG, Liljenberg B, Lindhe J. Dynamics of Bio-Oss Collagen incorporation in fresh extraction wounds: an experimental study in the dog. Clinical Oral Implants Research 2010;21:55-64. 
35. Ghanaati S, Orth C, Barbeck M, Willershausen I, Thimm BW, Booms P, et al. Histological and histomorphometrical analysis of a silica matrix embedded nanocrystalline hydroxyapatite bone substitute using the subcutaneous implantation model in Wistar rats. Biomedical Materials 2010;5:035005.

36. Strietzel FP, Reichart PA, Graf HL. Lateral alveolar ridge augmentation using a synthetic nanocrystalline hydroxyapatite bone substitution material (Ostim): preliminary clinical and histological results. Clinical Oral Implants Research 2007;18:743-751.

37. Chitsazi MT, Shirmohammadi A, Faramarzie M, Pourabbas R, Rostamzadeh An. A clinical comparison of nano-crystalline hydroxyapatite (Ostim) and autogenous bone graft in the treatment of periodontal intrabony defects. Medicina Oral Patologia Oral y Cirugia Bucal 2011;16:e448-e453.

38. Checchi V, Savarino L, Montevecchi M, Felice P, Checchi L. Clinical-radiographic and histological evaluation of two hydroxyapatites in human extraction sockets: a pilot study. International Journal of Oral and Maxillofacial Surgery 2011;40:526-32.

39. Lee DW, Pi SH, Lee SK, Kim EC. Comparative histomorphometric analysis of extraction sockets healing implanted with bovine xenografts, irradiated cancellous allografts, and solvent-dehydrated allografts in humans. The International Journal of Oral \& Maxillofacial Implants 2009;24:609-615.

40. Baldini N, De Sanctis M, Ferrari M. Deproteinized bovine bone in periodontal and implant surgery. Dental Materials 2011;27:61-70.

41. Annalisa P, Furio P, Ilaria Z, Anna A, Luca S, Marcella M, et al. Anorganic bovine bone and a silicatebased synthetic bone activate different microRNAs. Journal of Oral Sciences 2008;50:301-307.

42. Rokn A, Moslemi N, Eslami B, Abadi HK, Paknejad M. Histologic Evaluation of Bone Healing Following Application of Anorganic Bovine Bone and $\beta$-tricalcium Phosphate in Rabbit Calvaria. Journal of Dentistry (Tehran, Iran) 2012;9:35-40.

43. Wallace SS, Froum SJ, Cho SC, Elian N, Monteiro D, Kim BS, et al. Sinus augmentation utilizing anorganic bovine bone (Bio-Oss) with absorbable and nonabsorbable membranes placed over the lateral window: histomorphometric and clinical analyses. The International Journal of Periodontics \& Restorative Dentistry 2005;25:551-559.

44. Perrott DH, Smith RA, Kaban LB. The use of fresh frozen allogeneic bone for maxillary and mandibular reconstruction. International Journal of Oral and Maxillofacial Surgery 1992;21:260-275. 
45. Shand JM, Heggie AA, Holmes AD, Holmes W. Allogeneic bone grafting of calvarial defects: an experimental study in the rabbit. International Journal of Oral and Maxillofacial Surgery 2002;31:525-531.

46. Rodella LF, Favero G, Boninsegna R, Borgonovo A, Rezzani R, Santoro F. TGF-beta1 and VEGF after fresh frozen bone allograft insertion in oral-maxillo-facial surgery. Histology and Histopathology 2010;25:463-471.

47. Spin-Neto R, Landazuri Del Barrio RA, Pereira LA, Marcantonio RA, Marcantonio E, Marcantonio E Jr. Clinical similarities and histological diversity comparing fresh frozen onlay bone blocks allografts and autografts in human maxillary reconstruction. Clinical Implant Dentistry and Related Research 2013;15:490-497.

48. Habibovic P, de Groot K. Osteoinductive biomaterials--properties and relevance in bone repair. Journal of Tissue Engineering and Regenerative Medicine 2007;1:25-32.

49. Donegan S, Williamson P, D'Alessandro U, et al. Combining individual patient data and aggregate data in mixed treatment comparison meta-analysis: Individual patient data may be beneficial if only for a subset of trials. Statistics in Medicine 2013;32:914-30.

50. Owen RK, Tincello DG, Keith RA. Network meta-analysis: development of a three-level hierarchical modeling approach incorporating dose-related constraints. Value in Health 2015;18:116-26.

51. Jones JK, Triplett RG. The relationship of cigarette smoking to impaired intraoral wound healing: a review of evidence and implications for patient care. Journal of Oral and Maxillofacial Surgery 1992;50:237-249.

52. Schulz KF, Altman DG, Moher D; CONSORT Group. CONSORT 2010 Statement: Updated guidelines for reporting parallel group randomised trials. Journal of Clinical Epidemiology 2010;63:834-840. 


\section{Tables}

Table 1 - Direct estimates of the primary outcome. AUT = autograft; ALL = allograft; SYN = synthetic bone graft; $\mathrm{XEN}=$ xenograft; $\mathrm{MD}=$ mean difference; $\mathrm{CI}$ = confidence interval; $\mathrm{UI}=$ uncertainty interval; $\mathrm{PrI}$ = predictive interval.

\begin{tabular}{lllllll}
\hline Comparison & Studies & MD (95\% CI) & $\mathbf{I}^{\mathbf{2}}$ (95\% UI) & tau $^{\mathbf{2}}$ & $\mathbf{9 5 \%}$ PrI & P \\
\hline AUT-ALL & 2 & $-6.00(-19.42,7.41)$ & $87 \%(-)$ & 82.75 & - & 0.380 \\
AUT-SYN & 2 & $-4.42(-9.75,0.91)$ & $68 \%(-)$ & 10.09 & - & 0.104 \\
AUT-XEN & 2 & $-21.62(-56.40,13.16)$ & $93 \%(-)$ & 587.86 & - & 0.223 \\
ALL-SYN & 1 & $25.33(13.59,37.07)$ & - & 0.00 & - & $<0.001$ \\
SYN-XEN & 5 & $0.90(-8.75,10.55)$ & $94 \%(89 \%, 96 \%)$ & 97.78 & $-34.25,36.05$ & 0.855 \\
\hline
\end{tabular}


Table 2 - Summary of our confidence in effect estimates and ranking of treatments according to the GRADE approach.

\begin{tabular}{|c|c|c|c|}
\hline Comparison & $\begin{array}{l}\text { Nature of the } \\
\text { evidence }\end{array}$ & Confidence & Downgrading due to ${ }^{a}$ \\
\hline Autograft vs allograft & Mixed & Low & Imprecision \\
\hline Autograft vs synthetic graft & Mixed & Moderate & Imprecision \\
\hline Autograft vs xenograft & Mixed & Very low & $\begin{array}{l}\text { Study limitations; inconsistency; } \\
\text { imprecision }\end{array}$ \\
\hline Allograft vs synthetic graft & Mixed & Very low & Inconsistency; imprecision \\
\hline Allograft vs xenograft & Indirect & Very low & Study limitations; imprecision \\
\hline Synthetic graft vs xenograft & Mixed & Very low & $\begin{array}{l}\text { Study limitations; inconsistency; } \\
\text { imprecision }\end{array}$ \\
\hline Ranking of treatments & & Moderate & Study limitations \\
\hline
\end{tabular}

aSee Appendix 18 for details on each judgement. 
Figure Legends

Fig. 1 - PRISMA flow diagram for study identification and selection.

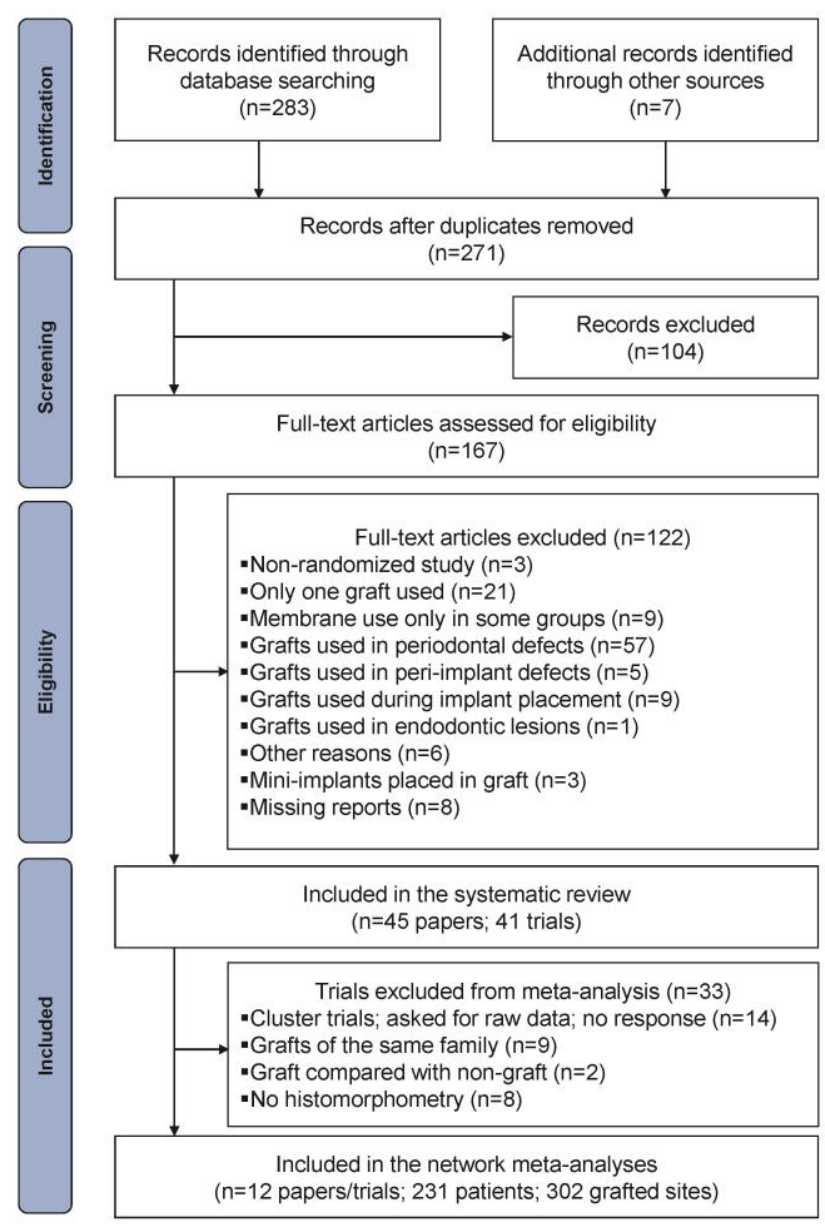


Fig. 2 - Network diagram for the primary outcome of \% new bone (12 studies; 231patients; 302 grafted sites). Joining lines indicate where head-to-head trials between interventions were identified and their risk of bias: green (low risk), yellow (moderate risk), and red (high risk). On each adjoining line is represented the number of contributing trials (number) and patients (number in parenthesis) for each comparison. Treatment nodes are proportionally sized to reflect the number of patients randomized to each intervention. AUT = autograft; ALL = allogeneic graft; SYN = synthetic bone graft; XEN = xenograft.

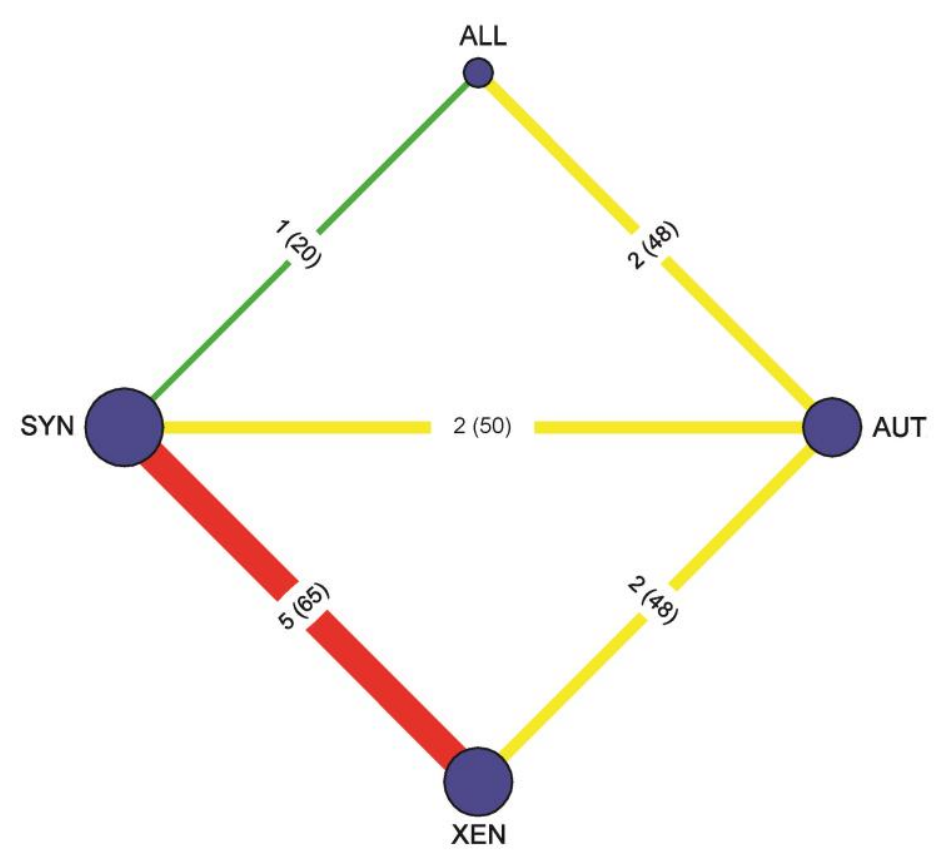


Fig. 3 - Predictive interval plot for the primary outcome network. The black solid lines represent the confidence intervals for the summary mean difference for each comparison and the dotted red lines the respective predictive intervals (possible values in a future trial). The blue vertical line is the line of no effect (mean difference equal to 0 ).

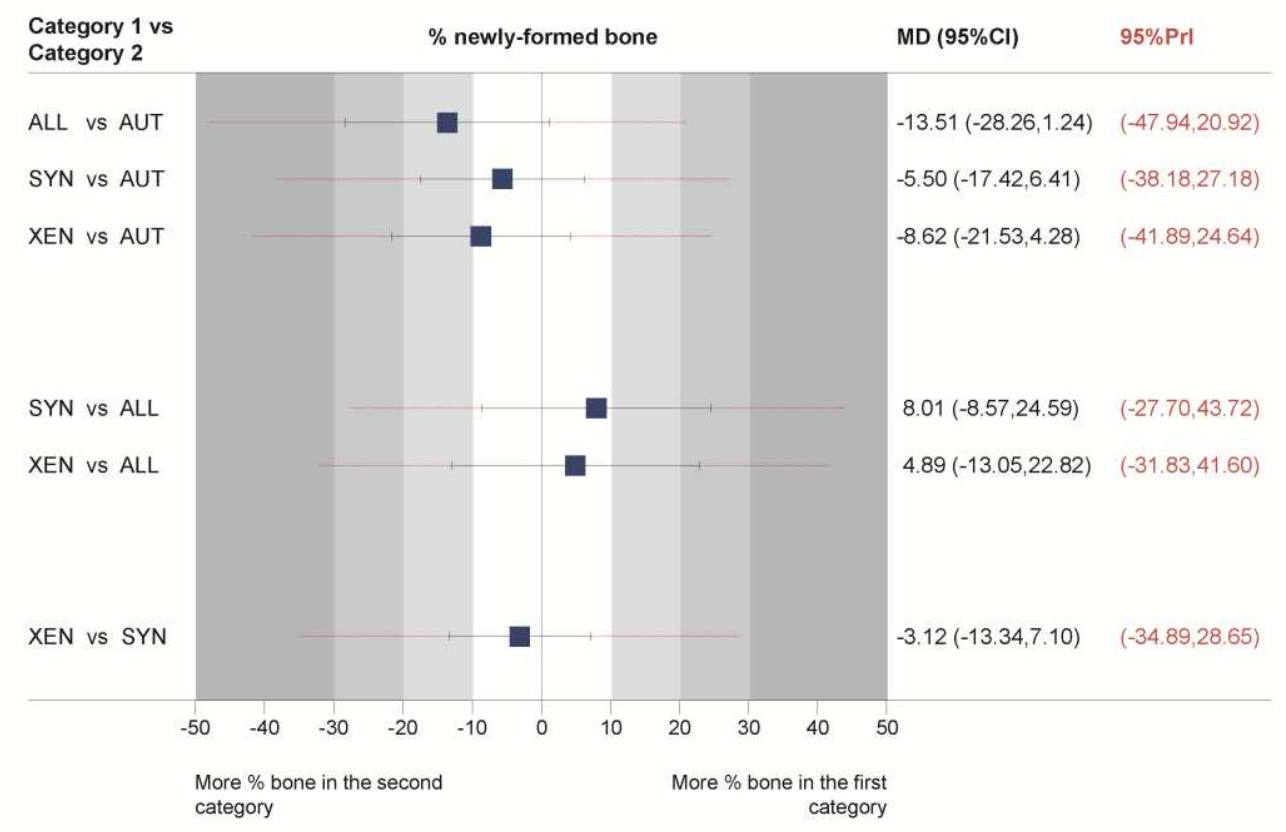


Fig. 4 - Plots of the surface under the cumulative ranking curves for all treatments in the primary outcome network. AUT = autograft; SYN = synthetic bone graft; XEN = xenograft; ALL = allograft.

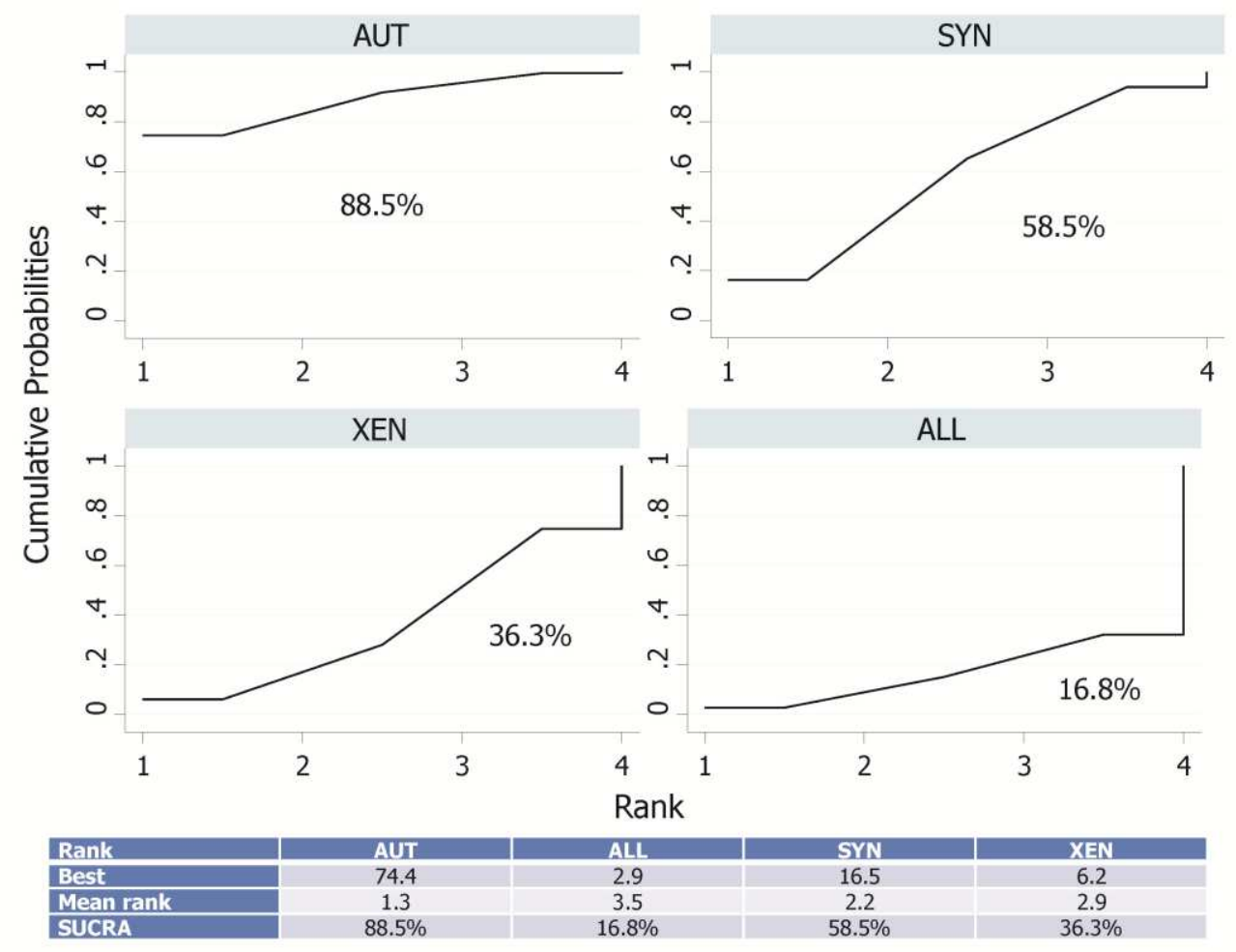




\section{Comparative effectiveness of natural and synthetic bone grafts in oral and maxillofacial surgery prior to insertion of dental implants:}

\section{systematic review and network meta-analysis of parallel and cluster randomized controlled trials}

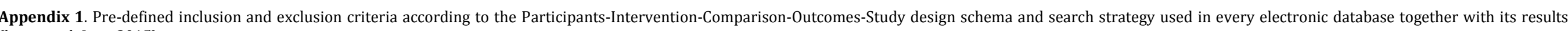
(last search June 2015).

\begin{tabular}{|c|c|c|}
\hline & Inclusion & Exclusion \\
\hline Participants & Patients of any age or sex in need of bone augmentation/preservation procedures in the oral cavity & Animal and in vitro studies. \\
\hline Intervention & $\begin{array}{l}\text { - Any kind of bone graft or filling material used for ridge augmentation, sinus lift, socket preservation or any other } \\
\text { bone-augmenting procedure. } \\
\text { - Combinations of grafts (almost universally of a non-autologous graft with some autologous graft) were eligible, only if } \\
\text { the actual \% contribution of each graft to the combination was reported. In this case, we classified the combination to } \\
\text { the graft providing over } 70 \% \text { of the whole. } \\
\text { - In case of graft combinations with equal (i.e. } 50 \%-70 \% \text { ) contributions from their components, the graft was not } \\
\text { classified in a graft category and the trial was included in the descriptive part, but not in the quantitative one. } \\
\text { - In case a trial did not report the contribution of each graft to a graft-combination, we included this study in the } \\
\text { descriptive part, but not in the quantitative synthesis. } \\
\text { - Membranes or other materials used to cover the surgical site will be eligible, but only if their use is consistent in all } \\
\text { experimental groups. }\end{array}$ & $\begin{array}{l}\text { - Studies that utilize immediate implant placement will be excluded, as } \\
\text { all included studies will have to utilize only bone-augmenting } \\
\text { procedures without any factor that could possibly intervene to bone } \\
\text { healing. } \\
\text { - Studies that investigate the use of bone grafts on already inserted } \\
\text { dental implants will also be excluded. } \\
\text { Bone grafting for periapical endodontic lesions or periodontic tooth } \\
\text { lesions will also be excluded, due to the risk of possibly impaired } \\
\text { wound healing / bone formation. }\end{array}$ \\
\hline Comparison & Any kind of bone graft or filling material. & $\begin{array}{l}\text { Untreated control groups will be excluded, as aim of this review is to } \\
\text { assess the comparative effectiveness of bone grafts. The absolute effects of } \\
\text { bone grafting have long been proved. }\end{array}$ \\
\hline Outcome - primary & $\begin{array}{l}\text { The primary outcome will be the \% of newly formed bone as measured through histomorphometric analyses of acquired } \\
\text { bone samples from the augmented sites. We will include all reported time-points after the surgical procedure and we } \\
\text { will stratify them, if possible. We anticipate that most assessments of newly-formed bone will take place during a } \\
\text { subsequent stage of implant insertion. }\end{array}$ & \\
\hline Outcome - secondary & $\begin{array}{l}\text { \% of remaining graft in the sample } \\
\text { \% of immature and mature bone in the sample } \\
\text { - } \% \text { of soft tissues in the sample } \\
\text { - adverse effects during the heasuring phase or bone status } \\
\text { - any outcome of periodontal health at the augmented or adjacent sites } \\
\text { - success and survival of dental implants inserted in the augmented bone on a secondary timepoint. }\end{array}$ & \\
\hline Study design & Randomized controlled trials (both parallel and clustered) in any clinical setting. & Non-randomized or non-clinical studies. \\
\hline \multicolumn{3}{|c|}{ Literature search } \\
\hline Database & Search & Limit \\
\hline $\begin{array}{l}\text { MEDLINE (through } \\
\text { Pubmed) }\end{array}$ & $\begin{array}{l}\text { (hydroxyapatite OR hydroxiapatite) AND ("bone substitute") OR ("bone graft") OR ("bone ceramic") OR ("ceramic } \\
\text { bone") OR ("bone substitute") OR ("bone substitute healing") OR ("bone tissue engineering") OR ("artificial bone")) AND } \\
\text { (("dental") OR ("dentistry") OR ("maxillofacial surgery") OR ("oral maxillofacial surgery") OR ("oral surgery") OR ("sinus } \\
\text { lift")) }\end{array}$ & Randomized Controlled Trial; Humans \\
\hline $\begin{array}{l}\text { Cochrane Library } \\
\text { (CENTRAL) }\end{array}$ & $\begin{array}{l}\text { (hydroxyapatite OR hydroxiapatite) AND ("bone substitute" OR "bone graft" OR "bone ceramic" OR "ceramic bone" OR } \\
\text { "bone substitute" OR "bone substitute healing" OR "bone tissue engineering" OR "artificial bone") AND ("dental" OR } \\
\text { "dentistry" OR "maxillofacial surgery" OR "oral maxillofacial surgery" OR "oral surgery" OR "sinus lift") }\end{array}$ & 47 \\
\hline Web of Knowledge & $\begin{array}{l}\text { (hydroxyapatite OR hydroxiapatite) AND ("bone substitute" OR "bone graft" OR "bone ceramic" OR "ceramic bone" OR } \\
\text { "bone substitute" OR "bone substitute healing" OR "bone tissue engineering" OR "artificial bone") AND ("dental" OR } \\
\text { "dentistry" OR "maxillofacial surgery" OR "oral maxillofacial surgery" OR "oral surgery" OR "sinus lift") AND random* }\end{array}$ & Dentistry oral surgery medicine \\
\hline Virtual Health Library & $\begin{array}{l}\text { (hydroxyapatite OR hydroxiapatite) AND ("bone substitute" OR "bone graft" OR "bone ceramic" OR "ceramic bone" OR } \\
\text { "bone substitute" OR "bone substitute healing" OR "bone tissue engineering" OR "artificial bone") AND ("dental" OR } \\
\text { "dentistry" OR "maxillofacial surgery" OR "oral maxillofacial surgery" OR "oral surgery" OR "sinus lift") AND random* }\end{array}$ & Limit to humans; exclude MEDLINE+CENTRAL \\
\hline
\end{tabular}


Appendix 2. Details of data synthesis and assessments of heterogeneity.

Heterogeneity in pairwise analyses was assessed with the $\mathrm{I}^{2}$ metric, defined as the proportion of total variability in the results explained by heterogeneity, and not chance (Higgins and Thompson 2002). The 95\% uncertainty intervals (95\% UI) (similar to CIs) around the $\mathrm{I}^{2}$ were calculated (Ioannidis et al. 2007) using the non-central $\chi^{2}$ approximation of $\mathrm{Q}$. For network meta-analysis, a common heterogeneity variable for all comparisons (tau) was assumed, which is the estimated standard deviation of underlying effects of treatment across studies in a meta-analysis (Salanti, 2012).

The absolute and relative presence of heterogeneity within pairwise meta-analyses was calcuated with the tau ${ }^{2}$ metric and $\mathrm{I}^{2}$ statistic, respectively. $\mathrm{I}^{2}$ thresholds were considered to represent heterogeneity that might not be important ( $0 \%$ to $40 \%$ ), might be moderate heterogeneity ( $30 \%$ to $60 \%$ ), might be substantial heterogeneity (50\% to $90 \%$ ), and might be considerable heterogeneity (75\% to $100 \%$ ), considering also the magnitude and direction of treatment effects and strength of evidence for heterogeneity.

The assumption of transitivity within the network was assessed by exploring the distribution of patient characteristics, similarity of interventions, and study design across comparisons. Based on the specific inclusion/exclusion criteria set, only adult patients (since insertion of dental implants is contraindicated in growing patients), with similar level of oral hygiene (having experienced tooth loss - i.e. in need of dental implants), and with similar medical history (compatible with the surgical insertion of implants) were included. Therefore, as all only randomized trials with general patient inclusion criteria were included in this systematic review, small deviations to patient characteristics are more likely to be due to chance, rather than real clinical inhomogeneity.

Evidence for consistency in the network was assessed in two ways. First, a loop-specific approach was used to investigate consistency within every closed triangular or quadratic loop in every network as the difference between direct and indirect estimates for a specific treatment comparison (inconsistency factor) in the loop (Salanti et al., 2009). Inconsistent loops were identified as those yielding a 95\% CI excluding zero. Second, the network-wide method of node-splitting was employed on a frequentist framework (Dias et al., 2010) to separates evidence on a particular comparison into "direct" and "indirect", by excluding one direct comparison at a time and estimating the indirect treatment effect for the excluded comparison (network sidesplit macro in Stata). Finally, the design-by-treatment interaction 
model was used that provides a single inference, using a $\chi^{2}$ test, about the plausibility of assuming consistency throughout the entire network and the model fit was compared to the original analysis (Higgins et al., 2012).

On a patient level, we made use of available raw data and fitted multivariable regression models to calculate the impact of any effect modifiers on the primary outcome. We then pooled the impact from each study across all studies to estimate its overall impact with random-effects meta-analyses. On a study level, we performed network meta-regression to explore sources of heterogeneity and/or inconsistency. When potential evidence of heterogeneity was identified, we first checked for any mistakes and inconsistencies in data extraction and entry. We then evaluated if the network meta-regression model fit was substantial altered compared to the original (by reestimating the models by maximum likelihood and performing a likelihood ratio test) and if so, treatments were re-ranked. 
1 AboElsaad NS, Soory M, Gadalla LM, Ragab LI, Dunne S, Zalata KR, et al. Effect of soft laser and bioactive glass on bone regeneration in the treatment of infra-bony defects (a clinical study). Lasers in medical science. 2009;24(3):387-95.

2 Abrahamsson P, Walivaara DA, Isaksson S, Andersson G. Periosteal expansion before local bone reconstruction using a new technique for measuring soft tissue profile stability: a clinical study. Journal of oral and maxillofacial surgery. 2012;70(10):e521-30.

Agarwal A, Gupta ND. Comparative evaluation of decalcified freeze-dried bone allograft use alone and in combination with polylactic acid, polyglycolic acid membrane in the treatment of noncontained human periodontal infrabony defects. Quintessence international (Berlin, Germany : 1985).

2012;43(9):761-8. Epub 2012/10/09.

Aimetti M, Pigella E, Romano F, Debernardi C. Treatment of mandibular class II furcation defects by the use of amelogenins and autologous bone. Two case reports. Minerva stomatologica. 2005;54(10):583-91. Epub 2005/10/15.

Alonso N, Tanikawa DY, Freitas Rda S, Canan L, Jr., Ozawa TO, Rocha DL. Evaluation of maxillary alveolar reconstruction using a resorbable collagen sponge with recombinant human bone morphogenetic protein-2 in cleft lip and palate patients. Tissue engineering Part C, Methods. 2010;16(5):1183-9. Epub 2010/02/19.

6 Annen BM, Ramel CF, Hammerle CH, Jung RE. Use of a new cross-linked collagen membrane for the treatment of peri-implant dehiscence defects: a randomised controlled double-blinded clinical trial. European journal of oral implantology. 2011;4(2):87-100. Epub 2011/08/03.

Antoun H, Sitbon JM, Martinez H, Missika P. A prospective randomized study comparing two techniques of bone augmentation: onlay graft alone or associated with a membrane. Clinical oral implants research. 2001;12(6):632-9. Epub 2001/12/12.

8 Barone A, Orlando B, Cingano L, Marconcini S, Derchi G, Covani U. A randomized clinical trial to evaluate and compare implants placed in augmented versus non-augmented extraction sockets: 3-year results. Journal of periodontology. 2012;83(7):836-46. Epub 2011/12/07.

Becker J, Al-Nawas B, Klein MO, Schliephake H, Terheyden H, Schwarz F. Use of a new cross-linked collagen membrane for the treatment of

9 dehiscence-type defects at titanium implants: a prospective, randomized-controlled double-blinded clinical multicenter study. Clinical oral implants research. 2009;20(7):742-9. Epub 2009/03/24.

10 Bettega G, Cinquin P, Lebeau J, Raphael B. Computer-assisted orthognathic surgery: clinical evaluation of a mandibular condyle repositioning system. Journal of oral and maxillofacial surgery. 2002;60(1):27-34; discussion -5. Epub 2002/01/05.

11 Blaszczyszyn A, Kubasiewicz-Ross P, Gedrange T, Dominiak M. Influence of semipermanent cement application used in immediately loaded, implantsupported restorations on crestal bone resorption. Annales Academiae Medicae Stetinensis. 2013;59(1):66-75. Epub 2013/01/01.

Boëck-Neto RJ, Gabrielli M, Lia R, Marcantonio E, Shibli JA. Histomorphometrical analysis of bone formed after maxillary sinus floor augmentation by

12 grafting with a combination of autogenous bone and demineralized freeze-dried bone allograft or hydroxyapatite. Journal of periodontology [Internet]. 2002; (3):[266-70 pp.].

13 Borges FL, Dias RO, Piattelli A, Onuma T, Gouveia Cardoso LA, Salomao M, et al. Simultaneous sinus membrane elevation and dental implant placement without bone graft: a 6-month follow-up study. Journal of periodontology. 2011;82(3):403-12. Epub 2010/11/09.

Brkovic BM, Prasad HS, Rohrer MD, Konandreas G, Agrogiannis G, Antunovic D, et al. Beta-tricalcium phosphate/type I collagen cones with or without

14 a barrier membrane in human extraction socket healing: clinical, histologic, histomorphometric, and immunohistochemical evaluation. Clinical oral investigations. 2012;16(2):581-90. Epub 2011/03/04

15 Burger EA, Meshkini H, Lindeboom JA. One versus two titanium screw fixation of autologous onlay bone grafts in the anterior maxilla: a randomised histological pilot study. European journal of oral implantology. 2011;4(3):219-25. Epub 2011/11/02.

Butz F, Bachle M, Ofer M, Marquardt K, Kohal RJ. Sinus augmentation with bovine hydroxyapatite/synthetic peptide in a sodium hyaluronate carrier

16 (PepGen P-15 Putty): a clinical investigation of different healing times. International journal of oral \& maxillofacial implants [Internet]. 2011;

Calongne KB, Aichelmann-Reidy ME, Yukna RA, Mayer ET. Clinical comparison of microporous biocompatible composite of PMMA, PHEMA and

17 calcium hydroxide grafts and expanded polytetrafluoroethylene barrier membranes in human mandibular molar Class II furcations. A case series. Journal of periodontology. 2001;72(10):1451-9. Epub 2001/11/09.

18 Canullo L, Dellavia C. Sinus lift using a nanocrystalline hydroxyapatite silica gel in severely resorbed maxillae: histological preliminary study. Clinical implant dentistry and related research. 2009;11 Suppl 1:e7-13. Epub 2009/02/18.

19 Chen CC, Wang HL, Smith F, Glickman GN, Shyr Y, O'Neal RB. Evaluation of a collagen membrane with and without bone grafts in treating periodontal intrabony defects. Journal of periodontology. 1995;66(10):838-47. Epub 1995/10/01.

Excluded by title/abstract

Excluded by title/abstract

Excluded by title/abstract

Excluded by title/abstract

Excluded by title/abstract

Excluded by title/abstract

Excluded by title/abstract

Excluded by title/abstract

Excluded by title/abstract

Excluded by title/abstract

Excluded by title/abstract

Excluded by title/abstract

Excluded by title/abstract

Excluded by title/abstract

Excluded by title/abstract

Excluded by title/abstract

Excluded by title/abstract

Excluded by title/abstract

Excluded by title/abstract 

Oral surgery, oral medicine, oral pathology, oral radiology, and endodontics. 1996;82(4):375-8. Epub 1996/10/01.

21 Choi KS, Kan JY, Boyne PJ, Goodacre CJ, Lozada JL, Rungcharassaeng K. The effects of resorbable membrane on human maxillary sinus graft: a pilot study. The International journal of oral \& maxillofacial implants. 2009;24(1):73-80. Epub 2009/04/07.

22 Cordaro L, Bosshardt DD, Palattella P, Rao W, Serino G, Chiapasco M. Maxillary sinus grafting with Bio-Oss (R) or Straumann (R) Bone Ceramic: histomorphometric results from a randomized controlled multicenter clinical trial. Clinical oral implants research. 2008;19(8):796-803. Cornelini R, Cangini F, Martuscelli G, Wennstrom J. Deproteinized bovine bone and biodegradable barrier membranes to support healing following immediate placement of transmucosal implants: a short-term controlled clinical trial. Int J Periodont Restor Dent. 2004;24(6):555-63.

24 Crespi R, Cappare P, Addis A, Gherlone E. Injectable Magnesium-Enriched Hydroxyapatite Putty in Peri-Implant Defects: A Histomorphometric Analysis in Pigs. International journal of oral \& maxillofacial implants. 2012;27(1):95-101.

25 Dahlin C, Simion M, Hatano N. Long-term follow-up on soft and hard tissue levels following guided bone regeneration treatment in combination with a xenogeneic filling material: a 5-year prospective clinical study. Clinical implant dentistry and related research [Internet]. 2010; (4):[263-70 pp.]

26 Del Fabbro M, Testori T, Francetti L, Weinstein D. Systematic review of survival rates for implants placed in the grafted maxillary sinus. International journal of periodontics \& restorative dentistry. 2004;24(6):565-+.

27 Engler-Hamm D, Cheung WS, Yen A, Stark PC, Griffin T. Ridge Preservation Using a Composite Bone Graft and a Bioabsorbable Membrane With and Without Primary Wound Closure: A Comparative Clinical Trial. Journal of periodontology. 2011;82(3):377-87.

Felice P, Cannizzaro G, Checchi V, Marchetti C, Pellegrino G, Censi P, et al. Vertical bone augmentation versus 7-mm-long implants in posterior atrophic mandibles. Results of a randomised controlled clinical trial of up to 4 months after loading. European journal of or al implantology. 2009;2(1):7-20. Epub 2010/05/15.

Felice P, Pellegrino G, Checchi L, Pistilli R, Esposito M. Vertical augmentation with interpositional blocks of anorganic bovine bone vs. 7-mm-long

29 implants in posterior mandibles: 1-year results of a randomized clinical trial. Clinical oral implants research. 2010;21(12):1394-403. Epub 2010/08/04.

30 Felice P, Pistilli R, Piattelli M, Soardi E, Barausse C, Esposito M. 1-stage versus 2-stage lateral sinus lift procedures: 1-year post-loading results of a multicentre randomised controlled trial. European journal of oral implantology. 2014;7(1):65-75. Epub 2014/06/04.

31 Felice P, Pistilli R, Piattelli M, Soardi E, Pellegrino G, Corvino V, et al. 1-stage versus 2-stage lateral maxillary sinus lift procedures: 4-month postloading results of a multicenter randomised controlled trial. European journal of oral implantology. 2013;6(2):153-65. Epub 2013/08/09.

Felice P, Soardi E, Piattelli M, Pistilli R, Jacotti M, Esposito M. Immediate non-occlusal loading of immediate post-extractive versus delayed placement

32 of single implants in preserved sockets of the anterior maxilla: 4-month post-loading results from a pragmatic multicentre randomised controlled trial. European journal of oral implantology. 2011;4(4):329-44. Epub 2012/01/28.

33 Filipek D, Koszowski R, Smieszek-Wilczewska J. A comparative clinical study on human tooth extractions: flap vs flapless buccal surgery. Quintessence international (Berlin, Germany : 1985). 2012;43(10):887-9. Epub 2012/11/02.

Friedmann A, Gissel K, Soudan M, Kleber BM, Pitaru S, Dietrich T. Randomized controlled trial on lateral augmentation using two collagen membranes: morphometric results on mineralized tissue compound. Journal of clinical periodontology. 2011;38(7):677-85. Epub 2011/05/12 Galindo-Moreno P, Avila G, Fernández-Barbero JE, Mesa F, O'Valle-Ravassa F, Wang HL. Clinical and histologic comparison of two different composite grafts for sinus augmentation: a pilot clinical trial. Clinical oral implants research [Internet]. 2008; (8):[755-9 pp.].

36 Gamal AY, Abdel-Ghaffar KA, Iacono VJ. A novel approach for enhanced nanoparticle-sized bone substitute adhesion to chemically treated periimplantitis-affected implant surfaces: an in vitro proof-of-principle study. Journal of periodontology. 2013;84(2):239-47. Epub 2012/05/05.

37 Gamal AY, Iacono VJ. Mixed nano/micro-sized calcium phosphate composite and EDTA root surface etching improve availability of graft material in intrabony defects: an in vivo scanning electron microscopy evaluation. Journal of periodontology. 2013;84(12):1730-9.

Gassling V, Purcz N, Braesen JH, Will M, Gierloff M, Behrens E, et al. Comparison of two different absorbable membranes for the coverage of lateral

38 osteotomy sites in maxillary sinus augmentation: a preliminary study. Journal of cranio-maxillo-facial surgery : official publication of the European Association for Cranio-Maxillo-Facial Surgery. 2013;41(1):76-82. Epub 2012/12/12.

Ghanaati S, Lorenz J, Obreja K, Choukroun J, Landes C, Sader RA. Nanocrystalline hydroxyapatite-based material already contributes to implant

39 stability after 3 months: a clinical and radiologic 3-year follow-up investigation. The Journal of oral implantology. 2014;40(1):103-9. Epub $2013 / 09 / 21$

40 Gher ME, Quintero G, Assad D, Monaco E, Richardson AC. Bone grafting and guided bone regeneration for immediate dental implants in humans. Journal of periodontology [Internet]. 1994; (9):[881-91 pp.].

Excluded by title/abstract

Excluded by title/abstract

Excluded by title/abstract

Excluded by title/abstract

Excluded by title/abstract

Excluded by title/abstract

Excluded by title/abstract

Excluded by title/abstract

Excluded by title/abstract

Excluded by title/abstract

Excluded by title/abstract

Excluded by title/abstract

Excluded by title/abstract

Excluded by title/abstract

Excluded by title/abstract

Excluded by title/abstract

Excluded by title/abstract

Excluded by title/abstract

Excluded by title/abstract

Excluded by title/abstract

Excluded by title/abstract 
43 Hashemi HM, Javidi B. Comparison between interpositional bone grafting and osteogenic alveolar distraction in alveolar bone reconstruction. Journal of oral and maxillofacial surgery. 2010;68(8):1853-8. Epub 2010/05/15.

44 Hellem S, Astrand P, Stenström B, Engquist B, Bengtsson M, Dahlgren S. Implant treatment in combination with lateral augmentation of the alveolar process: a 3-year prospective study. Clinical implant dentistry and related research [Internet]. 2003; (4):[233-40 pp.].

45 Hoad-Reddick G, Grant AA, McCord JF. Osseoretention? Comparative assessment of particulate hydroxyapatite inserted beneath immediate dentures. European journal of prosthodontics and restorative dentistry [Internet]. 1994; (2):[61-5 pp.].

46 Hong J-Y, Lee J-S, Pang E-K, Jung U-W, Choi S-H, Kim C-K. Impact of different synthetic bone fillers on healing of extraction sockets: an experimental study in dogs. Clinical oral implants research. 2014;25(2):E30-E7.

47 Jain A, Dixit J, Prakash D. Modulatory effects of Cissus quadrangularis on periodontal regeneration by bovine-derived hydroxyapatite in intrabony defects: exploratory clinical trial. Journal of the International Academy of Periodontology [Internet]. 2008; (2):[59-65 pp.].

48 Jensen T, Schou S, Gundersen HJG, Forman JL, Terheyden H, Holmstrup P. Bone-to-implant contact after maxillary sinus floor augmentation with BioOss and autogenous bone in different ratios in mini pigs. Clinical oral implants research. 2013;24(6):635-44.

49 Jung RE, Halg GA, Thoma DS, Hammerle CH. A randomized, controlled clinical trial to evaluate a new membrane for guided bone regeneration around dental implants. Clinical oral implants research. 2009;20(2):162-8. Epub 2009/02/05.

Jung RE, Siegenthaler DW, Hammerle CH. Postextraction tissue management: a soft tissue punch technique. Int J Periodont Restor Dent. 2004;24(6):545-53. Epub 2005/01/01.

51 Kang MG, Yun KI, Kim CH, Park JU. Postoperative condylar position by sagittal split ramus osteotomy with and without bone graft. Journal of oral and maxillofacial surgery. 2010;68(9):2058-64. Epub 2010/08/24.

Kattimani VS, Bajantai NV, Sriram SK, Sriram RR, Rao VK, Desai PD. Observer strategy and radiographic classification of healing after grafting of cystic defects in maxilla: a radiological appraisal. The journal of contemporary dental practice. 2013;14(2):227-32. Epub 2013/07/03.

Keller U, Sitzmann F. [Hydroxyapatite as an alloplastic bone substitute for the treatment of periodontal bone defects]. Deutsche zahnärztliche Zeitschrift [Internet]. 1988; (1):[64-7 pp.]

4 Kim DM, Nevins M, Camelo M, Schupbach P, Kim SW, Camelo JM, et al. The feasibility of demineralized bone matrix and cancellous bone chips in conjunction with an extracellular matrix membrane for alveolar ridge preservation: a case series. Int J Periodont Restor Dent 2011;31:39-47.

55 Kim SG, Kim HK, Lim SC. Combined implantation of particulate dentine, plaster of Paris, and a bone xenograft (Bio-Oss (R)) for bone regeneration in rats. Journal of Cranio-Maxillofacial Surgery. 2001;29(5):282-8.

56 Kimble KM, Eber RM, Soehren S, Shyr Y, Wang HL. Treatment of gingival recession using a collagen membrane with or without the use of demineralized freeze-dried bone allograft for space maintenance. Journal of periodontology. 2004;75(2):210-20. Epub 2004/04/08.

Kishore DT, Bandiwadekar T, Padma R, Debunath S, Profulla, Reddy A. Evaluation of relative efficacy of beta-tricalcium phosphate with and without 2013;14(2):193-201. Epub 2013/07/03.

58 Klongnoi B, Rupprecht S, Kessler P, Zimmermann R, Thorwarth M, Pongsiri S, et al. Lack of beneficial effects of platelet-rich plasma on sinus augmentation using a fluorohydroxyapatite or autogenous bone: an explorative study. Journal of clinical periodontology. 2006;33(7):500-9.

Kohal RJ, Mellas P, Hurzeler MB, Trejo PM, Morrison E, Caffesse RG. The effects of guided bone regeneration and grafting on implants placed into immediate extraction sockets. An experimental study in dogs. Journal of periodontology. 1998;69(8):927-37.

60 Kumar Raja D, Anantanarayanan P, Christabel A, Manikandhan R, Elavazhagan N, Naveen Kumar J. Donor site analgesia after anterior iliac bone grafting in paediatric population: a prospective, triple-blind, randomized clinical trial. Int J Oral Maxillofac Surg. 2014;43(4):422-7.

Lang NP, Tonetti MS, Suvan JE, Pierre Bernard J, Botticelli D, Fourmousis I, et al. Immediate implant placement with transmucosal healing in areas of aesthetic priority. A multicentre randomized-controlled clinical trial I. Surgical outcomes. Clinical oral implants research. 2007;18(2):188-96.

62 Lindeboom JA, van den Akker HP. A prospective placebo-controlled double-blind trial of antibiotic prophylaxis in intraoral bone grafting procedures: a pilot study. Oral surgery, oral medicine, oral pathology, oral radiology, and endodontics. 2003;96(6):669-72. Epub 2003/12/17.

Excluded by title/abstract Excluded by title/abstract Excluded by title/abstract Excluded by title/abstract Excluded by title/abstract

Excluded by title/abstract

Excluded by title/abstract Excluded by title/abstract Excluded by title/abstract Excluded by title/abstract 

of periodontology. 2008;79(1):72-9. Epub 2008/01/02.

Marukawa E, Oshina H, Iino G, Morita K, Omura K. Reduction of bone resorption by the application of platelet-rich plasma (PRP) in bone grafting of

the alveolar cleft. Journal of cranio-maxillo-facial surgery : official publication of the European Association for Cranio-Maxillo-Facial Surgery. 2011;39(4):278-83. Epub 2010/06/15.

65 Mazzocco F, Nart J, Cheung WS, Griffin TJ. Prospective evaluation of the use of motorized ridge expanders in guided bone regeneration for future implant sites. Int J Periodont Restor Dent. 2011;31(5):547-54. Epub 2011/08/17.

66 McAllister BS, Haghighat K, Prasad HS, Rohrer MD. Histologic evaluation of recombinant human platelet-derived growth factor-BB after use in extraction socket defects: a case series. Int J Periodont Restor Dent. 2010;30(4):365-73. Epub 2010/07/29.

67 Menicucci G, Mussano F, Schierano G, Rizzati A, Aimetti M, Gassino G, et al. Healing properties of implants inserted concomitantly with anorganic bovine bone. A histomorphometric human study. Australian dental journal. 2013;58(1):57-66. Epub 2013/02/28.

68 Nagaveni NB, Praveen RB, Umashankar KV, Pranav B, Sreedevi R, Radhika NB. Efficacy of platelet-rich-plasma (PRP) in bone regeneration after cyst enucleation in pediatric patients--a clinical study. The Journal of clinical pediatric dentistry. 2010;35(1):81-7. Epub 2010/12/31.

69 Nevins M, Camelo M, De Paoli S, Friedland B, Schenk RK, Parma-Benfenati S, et al. A study of the fate of the buccal wall of extraction sockets of teeth with prominent roots. Int J Periodont Restor Dent. 2006;26(1):19-29. Epub 2006/03/07.

70 Nevins ML, Camelo M, Nevins M, Schupbach P, Friedland B, Camelo JM, et al. Minimally invasive alveolar ridge augmentation pro cedure (tunneling technique) using rhPDGF-BB in combination with three matrices: a case series. Int J Periodont Restor Dent. 2009;29(4):371-83.

Nevins ML, Camelo M, Schupbach P, Kim DM, Camelo JM, Nevins M. Human histologic evaluation of mineralized collagen bone substitute and

71 recombinant platelet-derived growth factor-BB to create bone for implant placement in extraction socket defects at 4 and 6 months: a case series. Int J Periodont Restor Dent. 2009;29(2):129-39. Epub 2009/05/05.

72 Norton MR, Wilson J. Dental implants placed in extraction sites implanted with bioactive glass: human histology and clinical outcome. The International journal of oral \& maxillofacial implants. 2002;17(2):249-57. Epub 2002/04/18.

73 Nuttall D, Birch A, Haines JF, Trail IA. Radiostereographic analysis of a shoulder surface replacement: Does hydroxyapatite have a place? Bone and Joint Journal [Internet]. 2014; (8):[1077-81 pp.].

74 Pappalardo S, Baglio OA, Frasca M, Grassi FR. [Alveolar ridge augmentation by means of onlay grafts harvested from mandibular symphysis]. Minerva stomatologica. 2004;53(4):143-50. Epub 2004/04/27. Correzione di creste ossee edentule mediante prelievi a onlay dalla sinfisi mentoniera.

75 Park SH, Wang HL. Clinical significance of incision location on guided bone regeneration: human study. Journal of periodontology. 2007;78(1):47-51. Epub 2007/01/04

76 Peled M, Aizenbud D, Horwitz J, Machtei EE. Treatment of osseous cleft palate defects: a preliminary evaluation of novel treatment modalities. The Cleft palate-craniofacial journal : official publication of the American Cleft Palate-Craniofacial Association. 2005;42(4):344-8.

Pietruska M, Skurska A, Pietruski J, Dolinska E, Arweiler N, Milewski R, et al. Clinical and radiographic evaluation of intrabony periodontal defect

77 treatment by open flap debridement alone or in combination with nanocrystalline hydroxyapatite bone substitute. Annals of Anatomy [Internet]. 2012; (6):[533-7 pp.].

78 Pinho MN, Roriz VL, Novaes AB, Jr., Taba M, Jr., Grisi MF, de Souza SL, et al. Titanium membranes in prevention of alveolar collapse after tooth extraction. Implant dentistry. 2006;15(1):53-61. Epub 2006/03/30.

79 Prosper L, Gherlone EF, Redaelli S, Quaranta M. Four-year follow-up of larger-diameter implants placed in fresh extraction sockets using a resorbable membrane or a resorbable alloplastic material. The International journal of oral \& maxillofacial implants. 2003;18(6):856-64.

80 Proussaefs PT, Valenci

81 Raghoebar GM, Liem RS, Bos RR, van der Wal JE, Vissink A. Resorbable screws for fixation of autologous bone grafts. Clinical oral implants research. 2006;17(3):288-93. Epub 2006/05/05.

Raghoebar GM, Slater JJ, Hartog L, Meijer HJ, Vissink A. Comparison of procedures for immediate reconstruction of large osseous defects resulting from removal of a single tooth to prepare for insertion of an endosseous implant after healing. Int J Oral Maxillofac Surg. 2009;38(7):736-43.

83 Roccuzzo M, Ramieri G, Bunino M, Berrone S. Autogenous bone graft alone or associated with titanium mesh for vertical alveolar ridge augmentation: a controlled clinical trial. Clinical oral implants research. 2007;18(3):286-94. Epub 2007/02/15.

Excluded by title/abstract

Excluded by title/abstract

Excluded by title/abstract

Excluded by title/abstract

Excluded by title/abstract

Excluded by title/abstract

Excluded by title/abstract

Excluded by title/abstract

Excluded by title/abstract

Excluded by title/abstract

Excluded by title/abstract

Excluded by title/abstract

Excluded by title/abstract

Excluded by title/abstract

Excluded by title/abstract

Excluded by title/abstract

Excluded by title/abstract

Excluded by title/abstract

Excluded by title/abstract

Excluded by title/abstract

Excluded by title/abstract 
86 Santos FA, Pochapski MT, Martins MC, Zenobio EG, Spolidoro LC, Marcantonio E, Jr. Comparison of Biomaterial Implants in the Dental Socket: Histological Analysis in Dogs. Clinical implant dentistry and related research. 2010;12(1):18-25.

87 Schlegel KA, Zimmermann R, Thorwarth M, Neukam F-W, Klongnoi B, Nkenke E, et al. Sinus floor elevation using autogenous bone or bone substitute combined with platelet-rich plasma. Oral Surgery Oral Medicine Oral Pathology Oral Radiology and Endodontology. 2007;104(3):E15-E25.

88 Schulz A, Hilgers RD, Niedermeier W. The effect of splinting of teeth in combination with reconstructive periodontal surgery in humans. Clinical oral investigations. 2000;4(2):98-105. Epub 2001/02/24.

Schwarz F, Bieling K, Latz T, Nuesry E, Becker J. Healing of intrabony peri-implantitis defects following application of a nanocrystalline

89 hydroxyapatite (Ostim) or a bovine-derived xenograft (Bio-Oss) in combination with a collagen membrane (Bio-Gide). A case series. Journal of clinical periodontology. 2006;33(7):491-9. Epub 2006/07/06

90 Schwarz F, Hegewald A, John G, Sahm N, Becker J. Four-year follow-up of combined surgical therapy of advanced peri-implantitis evaluating two Schwarz F, Hegewald A, John G, Sahm N, Becker J. Four-year follow-up of combined surgical therapy of advanced pe
methods of surface decontamination. Journal of clinical periodontology. 2013;40(10):962-7. Epub 2013/08/13.

91 Schwarz F, Sahm N, Becker J. Impact of the outcome of guided bone regeneration in dehiscence-type defects on the long-term stability of peri-implant health: clinical observations at 4 years. Clinical oral implants research. 2012;23(2):191-6. Epub 2011/08/03.

2 Schwarz F, Sahm N, Iglhaut G, Becker J. Impact of the method of surface debridement and decontamination on the clinical outcome following combined surgical therapy of peri-implantitis: a randomized controlled clinical study. Journal of clinical periodontology. 2011;38(3):276-84.

93 Shoreibah EA, Ibrahim SA, Attia MS, Diab MM. Clinical and radiographic evaluation of bone grafting in corticotomy-facilitated orthodontics in adults. Journal of the International Academy of Periodontology. 2012;14(4):105-13. Epub 2012/12/06.

94 Stavropoulos A, Sculean A, Karring T. GTR treatment of intrabony defects with PLA/PGA copolymer or collagen bioresorbable membranes in combination with deproteinized bovine bone (Bio-Oss). Clinical oral investigations. 2004;8(4):226-32. Epub 2004/12/08.

95 Stavropoulos A, Sima C, Sima A, Nyengaard J, Karring T, Sculean A. Histological evaluation of healing after transalveolar maxillary sinus augmentation with bioglass and autogenous bone. Clinical oral implants research. 2012;23(1):125-31. Epub 2011/04/21.

Stübinger S, Saldamli B, Seitz O, Sader R, Landes CA. Palatal versus vestibular piezoelectric window osteotomy for maxillary sinus elevation: a

96 comparative clinical study of two surgical techniques. Oral surgery, oral medicine, oral pathology, oral radiology, and endodontics [Internet]. 2009; (5):[648-55 pp.].

Tawil G, Mawla M. Sinus floor elevation using a bovine bone mineral (Bio-Oss) with or without the concomitant use of a bilayered collagen barrier

97 (Bio-Gide): a clinical report of immediate and delayed implant placement. The International journal of oral \& maxillofacial implants. 2001;16(5):71321. Epub 2001/10/24.

Telleman G, Albrektsson T, Hoffman M, Johansson CB, Vissink A, Meijer HJ, et al. Peri-implant endosseous healing properties of dual acid-etched mini-

98 implants with a nanometer-sized deposition of $\mathrm{CaP}$ : a histological and histomorphometric human study. Clinical implant dentistry and related implants with a nanometer-sized deposition of CaP:
research. 2010;12(2):153-60. Epub 2009/05/15.

99 Thuaksuban N, Nuntanaranont T, Pripatnanont P. A comparison of autogenous bone graft combined with deproteinized bovine bone and autogenous bone graft alone for treatment of alveolar cleft. Int J Oral Maxillofac Surg. 2010;39(12):1175-80. Epub 2010/09/04.

Torres J, Tamimi F, Alkhraisat MH, Manchon A, Linares R, Prados-Frutos JC, et al. Platelet-rich plasma may prevent titanium-mesh exposure in alveolar ridge augmentation with anorganic bovine bone. Journal of clinical periodontology. 2010;37(10):943-51. Epub 2010/08/28.

101 healing and hypoaesthesia in lower lip after sagittal split ramus osteotomy. Journal of cranio-maxillo-facial surgery : official publication of the European Association for Cranio-Maxillo-Facial Surgery. 2012;40(4):e119-24. Epub 2011/08/17.

102 Zabeu JLA, Mercadante MT. [Bone graft substitutes compared to autologous bone graft in orthopedic surgery: systematic literature review]. Rev. bras ortop; 43(3): 59-68, mar. 2008. tab

103 Zitzmann NU, Naef R, Scharer P. Resorbable versus nonresorbable membranes in combination with Bio-Oss for guided bone regeneration. The International journal of oral \& maxillofacial implants. 1997;12(6):844-52. Epub 1998/01/13.

Zuffetti F, Esposito M, Capelli M, Galli F, Testori T, Del Fabbro M. Socket grafting with or without buccal augmentation with anor ganic bovine bone at

104 immediate post-extractive implants: 6-month after loading results from a multicenter randomised controlled clinical trial. European journal of oral implantology. 2013;6(3):239-50. Epub 2013/11/02.

Excluded by title/abstract

Excluded by title/abstract

Excluded by title/abstract

Excluded by title/abstract

Excluded by title/abstract

Excluded by title/abstract

Excluded by title/abstract

Excluded by title/abstract

Excluded by title/abstract

Excluded by title/abstract

Excluded by title/abstract

Excluded by title/abstract

Excluded by title/abstract

Excluded by title/abstract

Excluded by title/abstract 

clinical study. International journal of periodontics \& restorative dentistry [Internet]. 2013; (2):[223-8 pp.].

Olson JW, Dent CD, Morris HF, Ochi S. Long-term assessment (5 to 71 months) of endosseous dental implants placed in the augmented maxillary sinus. Annals of periodontology / the American Academy of Periodontology [Internet]. 2000; (1):[152-6 pp.].

107

icente JC, Hernandez-Vallejo G, Brana-Abascal P, Pena I. Maxillary sinus augmentation with autologous bone harvested from the lateral maxillary wall combined with bovine-derived hydroxyapatite: clinical and histologic observations. Clinical oral implants research [Internet]. 2010; (4). Esposito M, Cannizzaro G, Soardi E, Pistilli R, Piattelli M, Corvino V, Felice P. Posterior atrophic jaws rehabilitated with prostheses supported by 6

$108 \mathrm{~mm}$-long, $4 \mathrm{~mm}$-wide implants or by longer implants in augmented bone. Preliminary results from a pilot randomised controlled trial. Eur J Oral Implantol 2012;5:19-33.

109

Esposito M, Piattelli M, Pistilli R, Pellegrino G, Felice P. Sinus lift with guided bone regeneration or anorganic bovine bone: 1-year post-loading results of a pilot randomised clinical trial. European journal of oral implantology. 2010;3(4):297-305.

110 Felice P, Scarano A, Pistilli R, Checchi L, Piattelli M, Pellegrino G, Esposito M. A comparison of two techniques to augment maxillary sinuses using the lateral window approach: rigid synthetic resorbable barriers versus anorganic bovine bone. Five-month post-loading clinical and histological results of a pilot randomised controlled clinical trial. European journal of oral implantology. 2009;2(4):293-306. Epub 2009/01/01.

111 Aimetti M, Romano F, Griga FB, Godio L. Clinical and histologic healing of human extraction sockets filled with calcium sulfate. The International journal of oral \& maxillofacial implants. 2009;24(5):902-9. Epub 2009/10/30.

112 Anderegg CR, Martin SJ, Gray JL, Mellonig JT, Gher ME. Clinical evaluation of the use of decalcified freeze-dried bone allograft with guided tissue regeneration in the treatment of molar furcation invasions. Journal of periodontology. 1991;62(4):264-8. Epub 1991/04/01.

113 Bhongade ML, Tiwari IR. A comparative evaluation of the effectiveness of an anorganic bone matrix/cell binding peptide with an open flap debridement in human infrabony defects: a clinical and radiographic study. The journal of contemporary dental practice. 2007;8(6):25-34. Canuto RA, Pol R, Martinasso G, Muzio G, Gallesio G, Mozzati M. Hydroxyapatite paste Ostim, without elevation of full-thickness flaps, improves

114 alveolar healing stimulating BMP- and VEGF-mediated signal pathways: an experimental study in humans. Clinical oral implants research. 2013;24 Suppl A100:42-8. Epub 2011/12/16.

Crespi R, Cappare P, Romanos GE, Mariani E, Benasciutti E, Gherlone E. Corticocancellous porcine bone in the healing of human extraction sockets:

115 combining histomorphometry with osteoblast gene expression profiles in vivo. The International journal of oral \& maxillofacial implants. 2011;26(4):866-72. Epub 2011/08/16

116 Dodson TB. Management of mandibular third molar extraction sites to prevent periodontal defects. Journal of oral and maxillofacial surgery. 2004;62(10):1213-24. Epub 2004/09/29.

117 Heberer S, Al-Chawaf B, Jablonski C, Nelson JJ, Lage H, Nelson K. Healing of ungrafted and grafted extraction sockets after 12 weeks: a prospective clinical study. The International journal of oral \& maxillofacial implants. 2011;26(2):385-92. Epub 2011/04/13.

118 Heinz B, Kasaj A, Teich M, Jepsen S. Clinical effects of nanocrystalline hydroxyapatite paste in the treatment of intrabony periodontal defects: a randomized controlled clinical study. Clinical oral investigations. 2010;14(5):525-31. Epub 2009/08/15.

Johansson LA, Isaksson S, Bryington M, Dahlin C. Evaluation of bone regeneration after three different lateral sinus elevation procedures using micro-

119 computed tomography of retrieved experimental implants and surrounding bone: a clinical, prospective, and randomized study. The International journal of oral \& maxillofacial implants. 2013;28(2):579-86. Epub 2013/03/26

120 Kutkut A, Andreana S, Kim HL, Monaco E, Jr. Extraction socket preservation graft before implant placement with calcium sulfate hemihydrate and platelet-rich plasma: a clinical and histomorphometric study in humans. Journal of periodontology. 2012;83(4):401-9. Epub 2011/08/25.

21 Munhoz EA, Ferreira Junior O, Yaedu RY, Granjeiro JM. Radiographic assessment of impacted mandibular third molar sockets filled with composite xenogenic bone graft. Dento maxillo facial radiology. 2006;35(5):371-5. Epub 2006/08/31.

22 Nahles S, Nack C, Gratecap K, Lage H, Nelson JJ, Nelson K. Bone physiology in human grafted and non-grafted extraction sockets--an immunohistochemical study. Clinical oral implants research. 2013;24(7):812-9. Epub 2012/04/03.

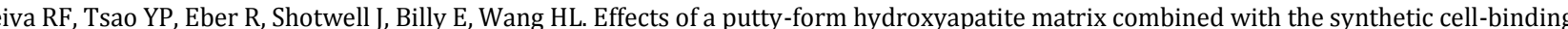
peptide P-15 on alveolar ridge preservation. Journal of periodontology. 2008;79(2):291-9. Epub 2008/02/07.

124 Rasperini G, Canullo L, Dellavia C, Pellegrini G, Simion M. Socket grafting in the posterior maxilla reduces the need for sinus augmentation. Int ] Periodont Restor Dent. 2010;30(3):265-73. Epub 2010/04/14.

125 Spinato S, Galindo-Moreno P, Zaffe D, Bernardello F, Soardi CM. Is socket healing conditioned by buccal plate thickness? A clinical and histologic study 4 months after mineralized human bone allografting. Clinical oral implants research. 2014;25(2):e120-6. Epub 2012/11/22.

Excluded; non-randomized

Excluded; non-randomized

Excluded; non-randomized

Excluded; only one graft used

Excluded; only one graft used

Excluded; only one graft used

Excluded; only one graft used

Excluded; only one graft used

Excluded; only one graft used

Excluded; only one graft used

Excluded; only one graft used

Excluded; only one graft used

Excluded; only one graft used

Excluded; only one graft used

Excluded; only one graft used

Excluded; only one graft used

Excluded; only one graft used

Excluded; only one graft used

Excluded; only one graft used

Excluded; only one graft used

Excluded; only one graft used 

extraction gingival closure with bone substitute and calcium sulphate. Medicina oral, patologia oral y cirugia bucal. 2010;15(5):e774-8. Van der Zee E, Oosterveld P, Van Waas MA. Effect of GBR and fixture installation on gingiva and bone levels at adjacent teeth. Clinical oral implants research. 2004;15(1):62-5. Epub 2004/01/21.

28 Coster P, Browaeys H, Bruyn H. Healing of extraction sockets filled with BoneCeramic $®$ prior to implant placement: preliminary histological findings. Clinical implant dentistry and related research [Internet]. 2011; (1):[34-45 pp.].

129 Boyne PJ, Lilly LC, Marx RE, Moy PK, Nevins M, Spagnoli DB, et al. De novo bone induction by recombinant human bone morphogenetic protein-2 (rhBMP-2) in maxillary sinus floor augmentation. Journal of oral and maxillofacial surgery. 2005;63(12):1693-707. Epub 2005/11/22.

30 Jung RE, Philipp A, Annen BM, Signorelli L, Thoma DS, Hammerle CH, et al. Radiographic evaluation of different techniques for ridge preservation after tooth extraction: a randomized controlled clinical trial. Journal of clinical periodontology. 2013;40(1):90-8. Epub 2012/11/21.

31 Schneider D, Schmidlin PR, Philipp A, Annen BM, Ronay V, Hammerle CH, et al. Labial soft tissue volume evaluation of different techniques for ridge preservation after tooth extraction: a randomized controlled clinical trial. Journal of clinical periodontology. 2014;41(6):612-7.

132 Thalmair T, Fickl S, Schneider D, Hinze M, Wachtel H. Dimensional alterations of extraction sites after different alveolar ridge preservation techniques - a volumetric study. Journal of clinical periodontology. 2013;40(7):721-7. Epub 2013/05/08.

Triplett RG, Nevins M, Marx RE, Spagnoli DB, Oates TW, Moy PK, et al. Pivotal, randomized, parallel evaluation of recombinant human bone

133 morphogenetic protein-2/absorbable collagen sponge and autogenous bone graft for maxillary sinus floor augmentation. Journal of oral and maxillofacial surgery. 2009;67(9):1947-60. Epub 2009/08/19.

34 Yilmaz S, Karaca EO, Ipci SD, Cakar G, Kuru BE, Kullu S, et al. Radiographic and histologic evaluation of platelet-rich plasma and bovine-derived xenograft combination in bilateral sinus augmentation procedure. Platelets. 2013;24(4):308-15. Epub 2012/06/23.

Chen ST, Darby IB, Reynolds EC. A prospective clinical study of non-submerged immediate implants: clinical outcomes and esthetic results. Clinical oral implants research. 2007;18(5):552-62. Epub 2007/07/05.

Friedmann A, Strietzel FP, Maretzki B, Pitaru S, Bernimoulin JP. Histological assessment of augmented jaw bone utilizing a new collagen barrier

membrane compared to a standard barrier membrane to protect a granular bone substitute material. Clinical oral implants research. 2002;13(6):587-94. Epub 2003/01/10 clinical trial. Journal of clinical periodontology. 2009;36(8):677-87. Epub 2009/07/01.

McGuire MK Kao RT Nevins M Lynch SE rhPDGF-BB promotes healing of periodontal defects: 24-month clinical and radiographic observatons. Int Periodont Restor Dent. 2006;26(3):223-31. Epub 2006/07/14.

Cortellini P, Tonetti MS. Clinical and radiographic outcomes of the modified minimally invasive surgical technique with and without regenerative materials: a randomized-controlled trial in intra-bony defects. Journal of clinical periodontology. 2011;38(4):365-73. Epub 2011/02/10.

140 De Leonardis D, Paolantonio M. Enamel matrix derivative, alone or associated with a synthetic bone substitute, in the treatment of 1- to 2-wall periodontal defects. Journal of periodontology. 2013;84(4):444-55. Epub 2012/05/23.

141 Demir B, Sengun D, Berberoglu A. Clinical evaluation of platelet-rich plasma and bioactive glass in the treatment of intra-bony defects. Journal of clinical periodontology. 2007;34(8):709-15. Epub 2007/07/20.

12 Dori F, Arweiler N, Gera I, Sculean A. Clinical evaluation of an enamel matrix protein derivative combined with either a natural bone mineral or betatricalcium phosphate. Journal of periodontology. 2005;76(12):2236-43. Epub 2005/12/08.

Dori F, Huszar T, Nikolidakis D, Tihanyi D, Horvath A, Arweiler NB, et al. Effect of platelet-rich plasma on the healing of intrabony defects treated with Beta tricalcium phosphate and expanded polytetrafluoroethylene membranes. Journal of periodontology. 2008;79(4):660-9.

Dori F, Kovacs V, Arweiler NB, Huszar T, Gera I, Nikolidakis D, et al. Effect of platelet-rich plasma on the healing of intrabony defects treated with an anorganic bovine bone mineral: a pilot study. Journal of periodontology. 2009;80(10):1599-605. Epub 2009/10/02.

45 Froum SJ, Weinberg MA, Tarnow D. Comparison of bioactive glass synthetic bone graft particles and open debridement in the treatment of human periodontal defects. A clinical study. Journal of periodontology. 1998;69(6):698-709. Epub 1998/07/11.

Gupta J, Gill AS, Sikri P. Evaluation of the relative efficacy of an alloplast used alone and in conjunction with an osteoclast inhibitor in the treatment of

14 human periodontal infrabony defects: a clinical and radiological study. Indian journal of dental research : official publication of Indian Society for Dental Research. 2011;22(2):225-31. Epub 2011/09/06.

Excluded; only one graft used

Excluded; graft membrane use not group-consistent

Excluded; graft membrane use not group-consistent

Excluded; graft membrane use not group-consistent

Excluded; graft membrane use not group-consistent

Excluded; graft membrane use not group-consistent

Excluded; graft membrane use not group-consistent

Excluded; graft membrane use not group-consistent

Excluded; graft membrane use not group-consistent

Excluded; graft membrane use not group-consistent

Excluded; graft used in periodontal defects.

Excluded; graft used in periodontal defects

Excluded; graft used in periodontal defects.

Excluded; graft used in periodontal defects.

Excluded; graft used in periodontal defects.

Excluded; graft used in periodontal defects

Excluded; graft used in periodontal defects.

Excluded; graft used in periodontal defects.

Excluded; graft used in periodontal defects. 

clinical and radiographic evaluation. Int J Oral Maxillofac Surg. 2012-41(12):1519-26. Epub 2012/04/10.

Jayakumar A, Rajababu P, Rohini S, Butchibabu K, Naveen A, Reddy PK, et al. Multi-centre, randomized clinical trial on the efficacy and safety of
recombinant human platelet-derived growth factor with beta-tricalcium phosphate in human intra-osseous periodontal defects. Journal of clinical periodontology. 2011;38(2):163-72. Epub 2010/12/08.

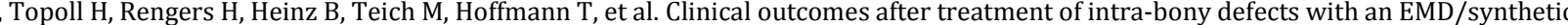
bone graft or EMD alone: a multicentre randomized-controlled clinical trial. Journal of clinical periodontology. 2008;35(5):420-8.

Kaushick BT, Jayakumar ND, Padmalatha O, Varghese S. Treatment of human periodontal infrabony defects with hydroxyapatite + beta tricalcium

150 phosphate bone graft alone and in combination with platelet rich plasma: a randomized clinical trial. Indian journal of dental research : official publication of Indian Society for Dental Research. 2011;22(4):505-10. Epub 2011/11/30

151 Keles GC, Cetinkaya BO, Albayrak D, Koprulu H, Acikgoz G. Comparison of platelet pellet and bioactive glass in periodontal regenerative therapy. Acta odontologica Scandinavica. 2006;64(6):327-33. Epub 2006/11/25

152

Kim CK, Choi EJ, Cho KS, Chai JK, Wikesjo UM. Periodontal repair in intrabony defects treated with a calcium carbonate implant and guided tissue regeneration. Journal of periodontology. 1996;67(12):1301-6. Epub 1996/12/01.

(2) versus bovine derived xenograft with amniotic membrane in human periodontal grade II furcation defects. Cell and tissue banking. 2009;10(4):317-26.

154 Lekovic V, Camargo PM, Weinlaender M, Kenney EB, Vasilic N. Combination use of bovine porous bone mineral, enamel matrix proteins, and a bioabsorbable membrane in intrabony periodontal defects in humans. Journal of periodontology. 2001;72(5):583-9. Epub 2001/06/08.

Mengel R, Soffner M, Flores-de-Jacoby L. Bioabsorbable membrane and bioactive glass in the treatment of intrabony defects in patients with generalized aggressive periodontitis: results of a 12-month clinical and radiological study. Journal of periodontology. 2003;74(6):899-908. Meyle J, Hoffmann T, Topoll H, Heinz B, Al-Machot E, Jervoe-Storm PM, et al. A multi-centre randomized controlled clinical trial on the treatment of intra-bony defects with enamel matrix derivatives/synthetic bone graft or enamel matrix derivatives alone: results after 12 months. Journal of clinical periodontology. 2011;38(7):652-60. Epub 2011/05/14

Mopur JM, Devi TR, Ali SM, Srinivasa TS, Gopinath V, Salam AR. Clinical and radiographic evaluation of regenerative potential of GTR membrane

157 (Biomesh(R)) along with alloplastic bone graft (Biograft(R)) in the treatment of periodontal intrabony defects. The journal of contemporary dental practice. 2013;14(3):434-9. Epub 2013/11/01.

Nevins M, Giannobile WV, McGuire MK, Kao RT, Mellonig JT, Hinrichs JE, et al. Platelet-derived growth factor stimulates bone fill and rate of attachment level gain: results of a large multicenter randomized controlled trial. Journal of periodontology. 2005;76(12):2205-15. Nygaard-Ostby P, Bakke V, Nesdal O, Susin C, Wikesjo UM. Periodontal healing following reconstructive surgery: effect of guided tissue regeneration clinical peresorbable barrier device when combined with autogen

Orsini M, Orsini G, Benlloch D, Aranda JJ, Lazaro P, Sanz M, et al. Comparison of calcium sulfate and autogenous bone graft to bioabsorbable

160 membranes plus autogenous bone graft in the treatment of intrabony periodontal defects: a split-mouth study. Journal of periodontology. 2001;72(3):296-302. Epub 2001/05/01.

Orsini M, Orsini G, Benlloch D, Aranda JJ, Sanz M. Long-term clinical results on the use of bone-replacement grafts in the treatment of intrabony

161 periodontal defects. Comparison of the use of autogenous bone graft plus calcium sulfate to autogenous bone graft covered with a bioabsorbable membrane. Journal of periodontology. 2008;79(9):1630-7. Epub 2008/09/06.

162 Ozcelik 0, Cenk Haytac M, Seydaoglu G. Enamel matrix derivative and low-level laser therapy in the treatment of intra-bony defects: a randomized placebo-controlled clinical trial. Journal of clinical periodontology. 2008;35(2):147-56. Epub 2007/12/18.

Paolantonio M, Femminella B, Coppolino E, Sammartino G, D'Arcangelo C, Perfetti G, et al. Autogenous periosteal barrier membranes and bone grafts

163 in the treatment of periodontal intrabony defects of single-rooted teeth: a 12-month reentry randomized controlled clinical trial. Journal of periodontology. 2010;81(11):1587-95. Epub 2010/06/30.

164 Park JS, Suh JJ, Choi SH, Moon IS, Cho KS, Kim CK, et al. Effects of pretreatment clinical parar

arameters on bioactive glass implantation in intrabony

radeep AR, Shetty SK, Garg G, Pai S. Clinical effectiveness of autologous platelet-rich plasma and Peptide-enhanced bone graft in the treatment of intrabony defects. Journal of periodontology. 2009;80(1):62-71. Epub 2009/02/21.

Prakash S, Sunitha J, Abid S. Evaluation of HTR polymer (Bioplant HTR) as a bone graft material in the treatment of interproximal vertical bony

166 defects: a clinical and radiological study. Indian journal of dental research : official publication of Indian Society for Dental Research. 2010;21(2):17984. Epub 2010/07/27.
Excluded; graft used in periodontal defects.

Excluded; graft used in periodontal defects.

Excluded; graft used in periodontal defects.

Excluded; graft used in periodontal defects.

Excluded; graft used in periodontal defects.

Excluded; graft used in periodontal defects.

Excluded; graft used in periodontal defects.

Excluded; graft used in periodontal defects.

Excluded; graft used in periodontal defects.

Excluded; graft used in periodontal defects.

Excluded; graft used in periodontal defects.

Excluded; graft used in periodontal defects.

Excluded; graft used in periodontal defects.

Excluded; graft used in periodontal defects.

Excluded; graft used in periodontal defects.

Excluded; graft used in periodontal defects.

Excluded; graft used in periodontal defects.

Excluded; graft used in periodontal defects.

Excluded; graft used in periodontal defects.

Excluded; graft used in periodontal defects. 

defects. Indian journal of dental research : official publication of Indian Society for Dental Research. 2009;20(4):471-9. class II furcation defects. The journal of contemporary dental practice. 2006;7(1):60-70. Epub 2006/02/24.

169

F intrabony defects in single-rooted teeth: a randomized clinical trial. Journal of periodontology. 2011;82(4):522-32. Epub 2010/11/09. periodontology. 2006;33(2):135-40. Epub 2006/01/31

Schwarz F, Sculean A, Georg T, Becker I. Clinical evaluation of the Er:YAG laser in combination with an enamel matrix protein derivative for the treatment of intrabony periodontal defects: a pilot study. Journal of clinical periodontology. 2003;30(11):975-81. Epub 2004/02/06.

A, Barbe G, Chiantella GC, Arweiler NB, Berakdar M, Brecx M. Clinical evaluation of an enamel matrix protein derivative combined with a bioactive glass for the treatment of intrabony periodontal defects in humans. Journal of periodontology. 2002;73(4):401-8. Epub 2002/05/07.

culean A, Berakdar M, Chiantella GC, Donos N, Arweiler NB, Brecx M. Healing of intrabony defects following treatment with a bovine-derived xenograft and collagen membrane. A controlled clinical study. Journal of clinical periodontology. 2003;30(1):73-80. Epub 2003/04/19.

174 Sculean A, Blaes A, Arweiler N, Reich E, Donos N, Brecx M. The effect of postsurgical antibiotics on the healing of intrabony defects following treatment with enamel matrix proteins. Journal of periodontology. 2001;72(2):190-5. Epub 2001/04/06

Sculean A, Chiantella GC, Windisch P, Gera I, Reich E. Clinical evaluation of an enamel matrix protein derivative (Emdogain) combined with a bovinederived xenograft (Bio-Oss) for the treatment of intrabony periodontal defects in humans. Int J Periodont Restor Dent. 2002;22(3):259-67. Epub 2002/08/21.

Sculean A, Pietruska M, Arweiler NB, Auschill TM, Nemcovsky C. Four-year results of a prospective-controlled clinical study evaluating healing of

176 intra-bony defects following treatment with an enamel matrix protein derivative alone or combined with a bioactive glass. Journal of clinica periodontology. 2007;34(6):507-13. Epub 2007/04/25.

177 Sculean A, Windisch P, Keglevich T, Gera I. Clinical and histologic evaluation of an enamel matrix protein derivative combined with a bioactive glass for the treatment of intrabony periodontal defects in humans. Int J Periodont Restor Dent. 2005;25(2):139-47. Epub 2005/04/21.

Shirmohammadi A, Chitsazi MT, Lafzi A. A clinical comparison of autogenous bone graft with and without autogenous periodontal ligament graft in the treatment of periodontal intrabony defects. Clinical oral investigations. 2009;13(3):279-86. Epub 2008/12/25

9 Slotte C, Asklow B, Sultan J, Norderyd 0 . A randomized study of open-flap surgery of 32 intrabony defects with and without adjunct bovine bone mineral treatment. Journal of periodontology. 2012;83(8):999-1007. Epub 2011/12/15.

Stavropoulos A, Karring ES, Kostopoulos L, Karring T. Deproteinized bovine bone and gentamicin as an adjunct to GTR in the treatment of intrabon defects: a randomized controlled clinical study. Journal of clinical periodontology. 2003;30(6):486-95. Epub 2003/06/11.

Stein JM, Fickl S, Yekta SS, Hoischen U, Ocklenburg C, Smeets R. Clinical evaluation of a biphasic calcium composite grafting material in the treatment

181 of human periodontal intrabony defects: a 12-month randomized controlled clinical trial. Journal of periodontology. 2009;80(11):1774-82. Epub 2009/11/13

182 Stratul SI, Schwarz F, Becker J, Willershausen B, Sculean A. Healing of intrabony defects following treatment with an oily calcium hydroxide suspension (Osteoinductal). A controlled clinical study. Clinical oral investigations. 2006;10(1):55-60. Epub 2005/12/21.

183 Subbaiah R, Thomas B. Efficacy of a bioactive alloplast, in the treatment of human periodontal osseous defects-a clinical study. Medicina oral, patologia oral y cirugia bucal. 2011;16(2):e239-44. Epub 2011/01/05.

Tonetti MS, Fourmousis I, Suvan J, Cortellini P, Bragger U, Lang NP. Healing, post-operative morbidity and patient perception of outcomes following regenerative therapy of deep intrabony defects. Journal of clinical periodontology. 2004;31(12):1092-8. Epub 2004/11/25.

185 Tsao YP, Neiva R, Al-Shammari K, Oh TJ, Wang HL. Factors influencing treatment outcomes in mandibular Class II furcation defects. Journal of periodontology. 2006;77(4):641-6. Epub 2006/04/06.

Vouros I, Aristodimou E, Konstantinidis A. Guided tissue regeneration in intrabony periodontal defects following treatment with two bioabsorbable membranes in combing

Epub 2004/09/16

187 Yadav VS, Narula SC, Sharma RK, Tewari S, Yadav R. Clinical evaluation of guided tissue regeneration combined with autogenous bone or autogenous bone mixed with bioactive glass in intrabony defects. Journal of oral science. 2011;53(4):481-8. Epub 2011/12/15.
Excluded; graft used in periodontal defects.

Excluded; graft used in periodontal defects.

Excluded; graft used in periodontal defects.

Excluded; graft used in periodontal defects.

Excluded; graft used in periodontal defects.

Excluded; graft used in periodontal defects.

Excluded; graft used in periodontal defects.

Excluded; graft used in periodontal defects.

Excluded; graft used in periodontal defects.

Excluded; graft used in periodontal defects.

Excluded; graft used in periodontal defects.

Excluded; graft used in periodontal defects.

Excluded; graft used in periodontal defects.

Excluded; graft used in periodontal defects.

Excluded; graft used in periodontal defects.

Excluded; graft used in periodontal defects.

Excluded; graft used in periodontal defects.

Excluded; graft used in periodontal defects.

Excluded; graft used in periodontal defects.

Excluded; graft used in periodontal defects.

Excluded; graft used in periodontal defects. 

hydroxyapatite (Ostim) or enamel matrix derivatives (Emdogain): A randomized controlled clinical trial. BioMed Research International 2014. Kaushick BT, Jayakumar ND, Padmalatha 0, Varghese S. Treatment of human periodontal infrabony defects with hydroxyapatite + ? tricalcium

189 phosphate bone graft alone and in combination with platelet rich plasma: a randomized clinical trial. Indian journal of dental research [Internet]. 2011; (4):[505-10 pp.].

190 Kumar PG, Kumar JA, Anumala N, Reddy KP, Avula H, Hussain SN. Volumetric analysis of intrabony defects in aggressive periodontitis patients following use of a novel composite alloplast: a pilot study. Quintessence international (Berlin, Germany : 1985) 2011; (5):[375-84 pp.].

191 Nazareth CA, Cury PR. Use of anorganic bovine-derived hydroxyapatite matrix/cell-binding peptide (P-15) in the treatment isolated Class I gingival recession of defects: a pilot study. Journal of periodontology [Internet]. 2011; (5):[700-7 pp.].

K, Tai H, Tanabe K, Suzuki H, Sato T, Kawase T, et al. Platelet-rich plasma combined with a porous hydroxyapatite graft for the treatment of intrabony periodontal defects in humans: a comparative controlled clinical study. Journal of periodontology. 2005; (6):[890-8 pp.].

193 Peres MF, Ribeiro ED, Casarin RC, Ruiz KG, Junior FH, Sallum EA, et al. Hydroxyapatite/?-tricalcium phosphate and enamel matrix derivative for treatment of proximal class II furcation defects: a randomized clinical trial. Journal of clinical periodontology [Internet]. 2013; (3):[252-9 pp.].

Santana RB, Mattos CM, Dyke T. Efficacy of combined regenerative treatments in human mandibular class II furcation defects. Journal of periodontology [Internet]. 2009; (11):[1756-64 pp.]

195 Chen ST, Darby IB, Adams GG, Reynolds EC. A prospective clinical study of bone augmentation techniques at immediate implants. Clinical oral implants research. 2005;16(2):176-84. Epub 2005/03/22.

Schwarz F, Sahm N, Bieling K, Becker J. Surgical regenerative treatment of peri-implantitis lesions using a nanocrystalline hydroxyapatite or a natural

196 bone mineral in combination with a collagen membrane: a four-year clinical follow-up report. Journal of clinical periodontology. 2009;36(9):807-14. Epub 2009/07/30.

Schwarz F, Sculean A, Bieling K, Ferrari D, Rothamel D, Becker J. Two-year clinical results following treatment of peri-implantitis lesions using a

197 nanocrystalline hydroxyapatite or a natural bone mineral in combination with a collagen membrane. Journal of clinical periodontology. 2008;35(1):80-7. Epub 2008/01/05.

198 Van Assche N, Michels S, Naert I, Quirynen M. Randomized controlled trial to compare two bone substitutes in the treatment of bony dehiscences. Clinical implant dentistry and related research. 2013;15(4):558-68. Epub 2012/01/13.

199 Wohlfahrt JC, Lyngstadaas SP, Ronold HJ, Saxegaard E, Ellingsen JE, Karlsson S, et al. Porous titanium granules in the surgical treatment of periimplant osseous defects: a randomized clinical trial. The International journal of oral \& maxillofacial implants. 2012;27(2):401-10.

Cannizzaro G, Felice P, Leone M, Viola P, Esposito M. Early loading of implants in the atrophic posterior maxilla: lateral sinus lift with autogenous

bone and Bio-Oss versus crestal mini sinus lift and 8-mm hydroxyapatite-coated implants. A randomised controlled clinical trial. European journal of oral implantology [Internet]. 2009; (1):[25-38 pp.].

Cannizzaro G, Felice P, Minciarelli AF, Leone M, Viola P, Esposito M. Early implant loading in the atrophic posterior maxilla: 1-stage lateral versus

201 crestal sinus lift and $8 \mathrm{~mm}$ hydroxyapatite-coated implants. A 5-year randomised controlled trial. European journal of oral implantology. 2013;6(1):13-25.

Artzi Z, Nemcovsky CE, Tal H, Dayan D. Histopathological morphometric evaluation of 2 different hydroxyapatite-bone derivatives in sinus augmentation procedures: a comparative study in humans. Journal of periodontology. 2001;72(7):911-20. Epub 2001/08/10.

Froum SJ, Tarnow DP, Wallace SS, Rohrer MD, Cho SC. Sinus floor elevation using anorganic bovine bone matrix (OsteoGraf/N) with and without

203 autogenous bone: a clinical, histologic, radiographic, and histomorphometric analysis--Part 2 of an ongoing prospective study. Int J Periodont Restor Dent. 1998;18(6):528-43. Epub 1999/05/13.

204 Trombelli L, Franceschetti G, Rizzi A, Minenna P, Minenna L, Farina R. Minimally invasive transcrestal sinus floor elevation with graft biomaterials. A randomized clinical trial. Clinical oral implants research [Internet]. 2012; (4):[424-32 pp.].

De Angelis N, Felice P, Pellegrino G, Camurati A, Gambino P, Esposito M. Guided bone regeneration with and without a bone substitute at single postextractive implants: 1 -year post-loading results from a pragmatic multicentre randomised controlled trial. European journal of oral implantology. 2011;4(4):313-25. Epub 2012/01/28.

206 Jung RE, Glauser R, Scharer P, Hammerle CH, Sailer HF, Weber FE. Effect of rhBMP-2 on guided bone regeneration in humans. Clinical oral implants research. 2003;14(5):556-68. Epub 2003/09/13.

Jung RE, Windisch SI, Eggenschwiler AM, Thoma DS, Weber FE, Hammerle CH. A randomized-controlled clinical trial evaluating clinical and placement

Excluded; grafts used with simultaneous implant placement

Excluded; grafts used with simultaneous implant placement

Excluded; grafts used with simultaneous implant placement

Excluded; grafts used with simultaneous implant placement

Excluded; grafts used with simultaneous implant placement

Excluded; grafts used with simultaneous implant placement

Excluded; grafts used with simultaneous implant placement 
Taschieri S, Testori T, Azzola F, Del Fabbro M, Valentini P. [Guided-tissue regeneration in endodontic surgery]. Revue de stomatologie et de chirurgie maxillo-faciale. 2008;109(4):213-7. Epub 2008/06/06. Regeneration tissulaire guidee en chirurgie endodontique.

210

sito M, Cannizzaro G, Soardi E, Pellegrino G, Pistilli R, Felice P. A 3-year post-loading report of a randomised controlled trial on the rehabilitation of posterior atrophic mandibles: short implants or longer implants in vertically augmented bone? Eur J Oral Implantol 2011;4:301-311.

211 Malmstrom J, Slotte C, Adolfsson E, Norderyd O, Thomsen P. Bone response to free form-fabricated hydroxyapatite and zirconia scaffolds: a histological study in the human maxilla. Clinical oral implants research. 2009;20(4):379-85. Epub 2009/03/21.

212 Rupprecht S, Petrovic L, Burchhardt B, Wiltfang J, Neukam FW, Schlegel KA. Antibiotic-containing collagen for the treatment of bone defects. Journal of biomedical materials research Part B, Applied biomaterials. 2007;83(2):314-9. Epub 2007/04/07.

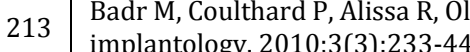

214 Cardaropoli D, Tamagnone L, Roffredo A, Gaveglio L, Cardaropoli G. Socket preservation using bovine bone mineral and collagen membrane: a randomized controlled clinical trial with histologic analysis. Int J Periodont Restor Dent. 2012;32(4):421-30.

215 Kao DW, Kubota A, Nevins M, Fiorellini JP. The negative effect of combining rhBMP-

-2 and Bio-Oss on bone formation for maxillary sinus

16 Kutkut A, Andreana S, Monaco E, Jr. Clinical and radiographic evaluation of single-tooth dental implants placed in grafted extraction sites: a one-year report. Journal of the International Academy of Periodontology. 2013;15(4):113-24. Epub 2013/12/25.

217 Merli M, Moscatelli M, Mariotti G, Rotundo R, Nieri M. Autogenous bone versus deproteinised bovine bone matrix in 1-stage lateral sinus floor elevation in the severely atrophied maxilla: a randomised controlled trial. Eur J Oral Implantol 2013;6:27-37.

218 Nevins ML, Camelo M, Schupbach P, Nevins M, Kim SW, Kim DM. Human buccal plate extraction socket regeneration with recombinant human platelet-derived growth factor BB or enamel matrix derivative. Int J Periodont Restor Dent. 2011;31(5):481-92. Epub 2011/08/17.

19 Oghli AA, Steveling H. Ridge preservation following tooth extraction: a comparison between atraumatic extraction and socket seal surgery. Quintessence international (Berlin, Germany : 1985). 2010;41(7):605-9. Epub 2010/07/09.

20 Rebaudi A, Silvestrini P, Trisi P. Use of a resorbable hydroxyapatite-collagen chondroitin sul

Lindgren C, Mordenfeld A, Hallman M. A prospective 1-year clinical and radiographic study of implants placed after maxillary sinus floor

221 augmentation with synthetic biphasic calcium phosphate or deproteinized bovine bone. Clinical implant dentistry and related research. 2012;14(1):41-50. Epub 2010/05/25.

222 Lindgren C, Mordenfeld A, Johansson CB, Hallman M. A 3-year clinical follow-up of implants placed in two different biomaterials used for sinus augmentation. The International journal of oral \& maxillofacial implants. 2012;27(5):1151-62. Epub 2012/10/12.

Lindgren C, Sennerby L, Mordenfeld A, Hallman M. Clinical histology of microimplants placed in two different biomaterials. The International journal of oral \& maxillofacial implants. 2009;24(6):1093-100. Epub 2010/02/18

Poulias E, Greenwell H, Hill M, Morton D, Vidal R, Shumway B, Peterson TL. Ridge preservation comparing socket allograft alone to socket allograft plus facial overlay xenograft: a clinical and histologic study in humans. J Periodontol. 2013 Nov;84(11):1567-75

225 Poulias E. Ridge preservation comparing the clinical and histologic healing of an intrasocket allograft vs. a facial overlay xenograft using a bioresorbable barrier membrane. University of Louisville 2012; Masters Thesis.

2008/02/01.

Included reports

227 Bettega G, Brun JP, Boutonnat J, Cracowski JL, Quesada JL, Hegelhofer $\mathrm{H}$, et al. Autologous platelet concentrates for bone graft enhancement in sinus

lift procedure. Transfusion. 2009;49(4):779-85. Epub 2009/01/28.
Calasans-Maia M, Resende R, Fernandes G, Calasans-Maia J, Alves AT, Granjeiro JM. A randomized controlled clinical trial to evaluate a new xenograft

for alveolar socket preservation. Clin Oral Implants Res. 2014 Oct;25(10):1125-30.

Excluded; grafts used with simultaneous implant placement

Excluded; grafts used in endodontic lesions.

Excluded; other reasons

Excluded; other reasons

Excluded; other reasons

Excluded; report unobtained

Excluded; report unobtained

Excluded; report unobtained

Excluded; report unobtained

Excluded; report unobtained

Excluded; report unobtained

Excluded; report unobtained

Excluded; report unobtained

Excluded; mini-implants placed in graft

Excluded; mini-implants placed in graft

Excluded; mini-implants placed in graft

Excluded; trial arms different both for graft and surgical technique

Excluded; trial arms different both for graft and surgical technique

Excluded; graft used in periapical cysts

Included in SR. excluded from NMA: cluster trial no raw data; requested through e-mail.

Included maually in SR; excluded from NMA:

compared grafts from the same graft family. 

extraction sockets: a pilot study. Int J Oral Maxillofac Surg. 2011;40(5):526-32. Epub 2011/02/02.

231 Cordaro L, Torsello F, Morcavallo S, di Torresanto VM. Effect of bovine bone and collagen membranes on healing of mandibular bone blocks: a prospective randomized controlled study. Clinical oral implants research. 2011;22(10):1145-50. Epub 2011/02/12.

Corinaldesi G, Piersanti L, Piattelli A, Iezzi G, Pieri F, Marchetti C. Augmentation of the floor of the maxillary sinus with recombinant human bone

232 morphogenetic protein-7: a pilot radiological and histological study in humans. The British journal of oral \& maxillofacial surgery. 2013;51(3):24752.

233 Crespi R, Cappare P, Gherlone E. Comparison of magnesium-enriched hydroxyapatite and porcine bone in human extraction socket healing: histologic and histomorphometric evaluation. The International journal of oral \& maxillofacial implants. 2011;26(5):1057-62. Epub 2011/10/20. Crespi R, Cappare P, Gherlone E. Magnesium-enriched hydroxyapatite compared to calcium sulfate in the healing of human extraction sockets: radiographic and histomorphometric evaluation at 3 months. Journal of periodontology. 2009;80(2):210-8. Epub 2009/02/04.

Crespi R, Mariani E, Benasciutti E, Cappare P, Cenci S, Gherlone E. Magnesium-enriched hydroxyapatite versus autologous bone in maxillary sinus rafting: combining histomorphometry with osteoblast gene expression profiles ex vivo. Journal of periodontology. 2009;80(4):586-93. de Freitas RM, Susin C, Spin-Neto R, Marcantonio C, Wikesjo UM, Pereira LA, et al. Horizontal ridge augmentation of the atrophic anterior maxilla

236 using rhBMP-2/ACS or autogenous bone grafts: a proof-of-concept randomized clinical trial. Journal of clinical periodontology. 2013;40(10):968-75 Epub 2013/09/04.

37 Felice P, Marchetti C, Piattelli A, Pellegrino G, Checchi V, Worthington H, et al Vertical ridge augmentation of the atrophic posterior mandible with interpositional block grafts: bone from the iliac crest versus bovine anorganic bone. Eur J Oral Implantology. 2008;1(3):183-98.

38 Froum S, Cho SC, Elian N, Rosenberg E, Rohrer M, Tarnow D. Extraction sockets and implantation of hydroxyapatites with membrane barriers: a histologic study. Implant dentistry. 2004;13(2):153-64. Epub 2004/06/05.

39 Froum S, Cho SC, Rosenberg E, Rohrer M, Tarnow D. Histological comparison of healing extraction sockets implanted with bioactive glass or demineralized freeze-dried bone allograft: a pilot study. Journal of periodontology. 2002;73(1):94-102. Epub 2002/02/16.

Froum SJ, Wallace SS, Cho SC, Elian N, Tarnow DP. Histomorphometric comparison of a biphasic bone ceramic to anorganic bovine bone for sinus augmentation: 6- to 8-month postsurgical assessment of vital bone formation. A pilot study. Int J Periodont Restor Dent. 2008;28:273-81.

41 Galindo-Moreno P, Moreno-Riestra I, Avila G, Padial-Molina M, Paya JA, Wang HL, et al. Effect of anorganic bovine bone to autogenous cortical bone ratio upon bone remodeling patterns following maxillary sinus augmentation. Clinical oral implants research. 2011;22(8):857-64.

242 Garlini G, Redemagni M, Canciani E, Dellavia C. Maxillary sinus fl oor augmentation with

Gholami GA, Najafi B, Mashhadiabbas F, Goetz W, Najafi S. Clinical, histologic and histomorphometric evaluation of socket preservation using a

243 synthetic nanocrystalline hydroxyapatite in comparison with a bovine xenograft: a randomized clinical trial. Clin Oral Implants Res. 2012 Oct;23(10):1198-204

Hermund NU, Stavropoulos A, Donatsky O, Nielsen H, Clausen C, Reibel J, et al. Reimplantation of cultivated human bone cells from the posterior

244 maxilla for sinus floor augmentation. Histological results from a randomized controlled clinical trial. Clinical oral implants research. 2012;23(9):1031-7. Epub 2011/11/19.

245 Jun SH, Ahn JS, Lee JI, Ahn KJ, Yun PY, Kim YK. A prospective study on the effectiveness of newly developed autogenous tooth bone graft material for sinus bone graft procedure. J Adv Prosthodont. 2014 Dec;6(6):528-38.

246 Koch FP, Becker J, Terheyden H, Capsius B, Wagner W. A prospective, randomized pilot study on the safety and efficacy of recombinant human growth and differentiation factor-5 coated onto $\beta$-tricalcium phosphate for sinus lift augmentation. Clin Oral Implants Res 2010;21:1301-8.

Kotsakis GA, Salama M, Chrepa V, Hinrichs JE, Gaillard P. A randomized, blinded, controlled clinical study of particulate anorganic bovine bone

mineral and calcium phosphosilicate putty bone substitutes for socket preservation. The International journal of oral \& maxillofacial implants. 2014;29(1):141-51. Epub 2014/01/24

Kuhl S, Gotz H, Brochhausen C, Jakse N, Filippi A, d'Hoedt B, et al. The influence of substitute materials on bone density after maxillary sinus augmentation: a microcomputed tomography study. The International journal of oral \& maxillofacial implants. 2012;27(6):1541-6.

Included in SR; excluded from NMA: compared grafts from the same graft family.

Included in SR; excluded from NMA: cluster trial no raw data; requested through e-mail.

Included in SR; excluded from NMA: compared grafts from the same graft family.

Included in SR; excluded from NMA: cluster trial no raw data; requested through e-mail.

Included in SR; excluded from NMA: cluster trial no raw data; requested through e-mail.

Included in SR; excluded from NMA: cluster trial no raw data; requested through e-mail.

Included in SR; excluded from NMA: cluster trial no raw data; requested through e-mail.

Included in SR; excluded from NMA: graft compared to growth factor.

Included in SR; excluded from NMA: cluster trial no raw data; requested through e-mail.

Included in NMA

Included in NMA

Included in NMA

Included in SR; excluded from NMA: compared grafts from the same graft family.

Included manually in NMA

Included manually in SR; excluded from NMA:

compared grafts from the same graft family.

Included in SR; excluded from NMA: compared grafts from the same graft family.

Included manually in NMA

Included in SR; excluded from NMA: compared grafts from the same graft family.

Included in SR; excluded from NMA: no

histomorphometry.

Included in SR; excluded from NMA: no

histomorphometry.

Included in SR; excluded from NMA: no

histomorphometry. 

comparative histomorphometric study. Journal of oral implantology [Internet]. 2012:[519-26 pp.].

Mineral and Autogenous Bone Mixture in Sinus Floor Augmentation: A Randomized Controlled Trial-Results After 4 Months of Healing. Journal of and Maxillofacial Surgery. 2011;69(1):160-9.

used for augmentation of the maxillary sinus floor? Clinical oral implants research. 2005:16(3):349-56. Epub 2005/05/10.

262

(a) periodontology. 2011;38(10):966-74. Epub 2011/07/30.

bo G, Huys L, Coulthard P, Maiorana C, Garagiola U, Barabas J, et al. A prospective multicenter randomized clinical trial of autogenous bone versus beta-tricalcium phosphate graft alone for bilateral sinus elevation: histologic and histomorphometric evaluation. The International journal of oral \& maxillofacial implants. 2005;20(3):371-81. Epub 2005/06/25

268 Tosta M, Cortes AR, Correa L, Pinto Ddos S, Jr., Tumenas I, Katchburian E. Histologic and histomorphometric evaluation of a synthetic bone substitute for maxillary sinus grafting in humans. Clinical oral implants research. 2013;24(8):866-70. Epub 2011/12/16.

269 Wagner W, Wiltfang J, Pistner H, Yildirim M, Ploder B, Chapman M, et al. Bone formation with a biphasic calcium phosphate combined with fibrin sealant in maxillary sinus floor elevation for delayed dental implant. Clinical oral implants research. 2012;23(9):1112-7. Epub 2012/08/16.

270 Wiltfang J, Schlegel KA, Schultze-Mosgau S, Nkenke E, Zimmermann R, Kessler P. Sinus floor augmentation with beta-tricalciumphosphate (beta-TCP): does platelet-rich plasma promote its osseous integration and degradation? Clinical oral implants research. 2003;14(2):213-8.

271 Wood RA, Mealey BL. Histologic comparison of healing after tooth extraction with ridge preservation using mineralized versus demineralized freezedried bone allograft. Journal of periodontology. 2012;83(3):329-36. Epub 2011/07/14.
Included in NMA

Included in SR; excluded from NMA: cluster trial no raw data adequately reported (patient clustering); requested through e-mail.

Included in SR; excluded from NMA: no histomorphometry.

Included in SR; excluded from NMA: no histomorphometry.

Included in SR; excluded from NMA: no histomorphometry.

Included in NMA

Included in SR; excluded from NMA: cluster trial no raw data; requested through e-mail. Included in SR; excluded from NMA: cluster trial no raw data; requested through e-mail.

Included in SR; excluded from NMA: no histomorphometry.

Included in SR; excluded from NMA: no

histomorphometry.

Included in SR; excluded from NMA: compared grafts from the same graft family.

Included in SR; excluded from NMA: cluster trial no raw data; requested through e-mail.

Included in SR; excluded from NMA: graft compared to graft with stem cells.

Included in SR; excluded from NMA: cluster trial no raw data; requested through e-mail.

Included in NMA

Included in SR; excluded from NMA: compared grafts from the same graft family.

Included in NMA

Included in NMA

Included in SR; excluded from NMA: cluster trial no raw data; requested through e-mail.

Included in SR; excluded from NMA: cluster trial no raw data; requested through e-mail.

Included in NMA 
Appendix 4. Demographics of the 41 trials included in this systematic review.

\begin{tabular}{|c|c|c|c|c|c|c|c|}
\hline $\mathrm{Nr}$ & Study & $\begin{array}{c}\text { Multi } \\
\text { center }\end{array}$ & Setting & $\begin{array}{l}\text { Raw } \\
\text { data }\end{array}$ & Country & $\begin{array}{l}\text { Patients } \\
(\mathrm{M} / \mathrm{F})\end{array}$ & $\begin{array}{l}\text { Age } \\
\text { (yrs) }\end{array}$ \\
\hline & Cluster trials & & & & & & \\
\hline 1 & Bettega 2009 & No & Clinic & No & France & $18(5 / 13)$ & 50.5 \\
\hline 2 & Cordaro 2008 & Yes & University/practice & No & Italy & $37(\mathrm{NR})$ & NR \\
\hline 3 & Corinaldesi 2013 & No & University & No & Italy & $9(3 / 6)$ & 50.0 \\
\hline 4 & Crespi 2009a ${ }^{\$}$ & No & University & No & Italy & $15(8 / 7)$ & 51.3 \\
\hline 5 & Crespi 2009b & No & University & No & Italy & $15(9 / 6)$ & 54.2 \\
\hline 6 & Crespi 2011\$ & No & University & No & Italy & $15(7 / 8)$ & 53.7 \\
\hline 7 & Felice 2008 & No & University & No & Italy & $10(4 / 6)$ & 54.0 \\
\hline 8 & Froum $2002^{\$}$ & No & University & Yes & USA & $19(12 / 7)$ & NR \\
\hline 9 & Froum 2004\$ & No & University & Yes & USA & $15(9 / 6)$ & 48.1 \\
\hline 10 & Froum 2008 & No & University & Yes & USA & 12 (NR) & NR \\
\hline 11 & Garlini 2014 & No & University & Yes & Italy & $5(2 / 3)$ & 57.0 \\
\hline 12 & Gholami 2012 & No & NR & No & Iran & $12(4 / 8)$ & 44.6 \\
\hline 13 & Kotsakis $2014^{\$}$ & No & University & No & USA & $18(12 / 6)$ & 41.6 \\
\hline 14 & Lee 2008 & No & Practice & Yes & USA & $41(14 / 27)$ & 59.0 \\
\hline 15 & Molly $2008^{\$}$ & No & University & No & Belgium & $8(1 / 7)$ & 53.0 \\
\hline 16 & Mordenfeld 2014 & No & University & No & Sweden & $13(6 / 7)$ & 59.6 \\
\hline 17 & Raghoebar 2005 & No & University & No & Netherlands & $5(2 / 3)$ & 58.4 \\
\hline 18 & Rickert 2011 & No & University & Yes & Netherlands & 12 (NR) & 60.8 \\
\hline 19 & Schmitt 2013 & No & University & No & Germany & $30(13 / 17)$ & NR \\
\hline 20 & Shirmohammadi 2014 & No & University & Yes & Iran & $10(8 / 2)$ & 54.0 \\
\hline 21 & Szabo 2005 & Yes & University/hospital & Yes & Belgium, Hungary, Italy, UK & $20(9 / 11)$ & 52.0 \\
\hline 22 & Wagner $2012^{\%}$ & Yes & University/hospital & No & Germany & 32 (NR) & NR \\
\hline 23 & Wiltfang 2003 & Yes & University & No & Germany & 39 (NR) & 46.0 \\
\hline \multirow[t]{2}{*}{24} & Xavier 2014 & No & University & Yes & Brazil & $15(8 / 7)$ & 54.0 \\
\hline & Parallel trials & & & & & & \\
\hline 25 & Calasans-Maia 2013 & No & University & - & Brazil & $20(7 / 13)$ & 44.6 \\
\hline 26 & Checci 2011 & No & University & - & Italy & $10(0 / 10)$ & 51.0 \\
\hline 27 & Cordaro 2011 & No & University & - & Italy & $17(\mathrm{NR})$ & 42.0 \\
\hline 28 & de Freitas 2013 & No & University & - & Brasil & $24(10 / 14)$ & 45.1 \\
\hline 29 & Galindo-Moreno 2011 & No & University & - & Spain & $28(18 / 10)$ & 47.3 \\
\hline 30 & Hermund 2012 & No & University & - & Denmark & $20(9 / 11)$ & 59.5 \\
\hline 31 & Jun 2014 & No & University & - & Republic of Korea & $38(24 / 14)$ & 58.2 \\
\hline 32 & Koch 2010; Stavropoulos 2011 & Yes & University & - & Germany & 20 (NR) & NR \\
\hline 33 & Kuhl 2012; Kuhl 2013 & No & University & - & Germany & $23(10 / 13)$ & 53.0 \\
\hline 34 & Kurkcu 2012 & No & University & - & Turkey & $23(12 / 11)$ & 48.7 \\
\hline 35 & $\begin{array}{l}\text { Mardas 2010; Mardas 2011; } \\
\text { Patel } 2013\end{array}$ & No & University & - & UK & $27(6 / 21)$ & 37.3 \\
\hline 36 & Meijndert 2005 \# & No & University & - & Netherlands & $10(5 / 5)$ & 35.2 \\
\hline 37 & Meijndert 2008 \# & Yes & University/hospital & - & Netherlands & $62(31 / 31)$ & 33.4 \\
\hline 38 & Piattelli 2002 & No & University & - & Italy & $18(12 / 6)$ & 49.0 \\
\hline 39 & Pikdoken 2011 & No & $\begin{array}{l}\text { Military medical } \\
\text { academy }\end{array}$ & - & Turkey & $24(15 / 9)$ & 58.9 \\
\hline 40 & Tosta 2013 & No & University & - & Brasil & 30 (NR) & NR \\
\hline 41 & Wood 2012 & No & University & - & USA & $33(13 / 20)$ & 56.7 \\
\hline
\end{tabular}

M, male; F, female; yrs, years; USA, United States of America; UK, United Kingdom; NR, not reported.

$\$$, some data from ungrafted control group omitted.

$\%$, some data from patients receiving only one graft material are omitted.

\#, some data due to inconsistent membrane use omitted. 
Appendix 5. Characteristics of the 41 trials included in this systematic review.

\begin{tabular}{|c|c|c|c|c|c|c|c|c|}
\hline $\mathrm{Nr}$ & Study & Surgery & Sites & Graft & Membrane & Imps & $\begin{array}{l}\text { Insertion } \\
\text { time (mos) }\end{array}$ & Conflict \\
\hline & Cluster trials & & & & & & & \\
\hline 1 & Bettega 2009 & SL & 36 & $\begin{array}{l}\text {-AUT (iliac) } \\
\text {-AUT (iliac)/PRP/fibrin glue }\end{array}$ & $\begin{array}{l}\text {-Fibrin glue } \\
\text {-Fibrin glue+PRP }\end{array}$ & 111 & 6 & Internal \\
\hline 2 & Cordaro 2008 & SL & 47 & $\begin{array}{l}\text {-XEN (Bio-Oss) } \\
\text {-SYN: BCP (BoneCeramic) }\end{array}$ & Collagen membrane & 109 & $6-8$ & NR \\
\hline 3 & Corinaldesi 2013 & SL & 18 & $\begin{array}{l}\text {-XEN (Bio-Oss) } \\
\text {-XEN (Bio-Oss)+GF: eptotermin (Osigraf) }\end{array}$ & Collagen membrane & NR & 4 & $\begin{array}{l}\text { Material } \\
\text { donation }\end{array}$ \\
\hline 4 & Crespi 2009a \$ & ESP & 30 & $\begin{array}{l}\text {-SYN: HA (Sintlife)\$ } \\
\text {-SYN: CS (Easy Set) }\end{array}$ & Collagen membrane & NR & 3 & None \\
\hline 5 & Crespi 2009b & SL & 30 & $\begin{array}{l}\text {-AUT (mandible) } \\
\text {-SYN: HA (Sintlife) }\end{array}$ & - & 60 & 5 & None \\
\hline 6 & Crespi $2011 \$$ & ESP & 30 & $\begin{array}{l}\text {-XEN (Tecnoss)\$ } \\
\text {-SYN: HA (Sintlife) }\end{array}$ & Collagen membrane & 30 & 4 & NR \\
\hline 7 & Felice 2008 & VRA & 20 & $\begin{array}{l}\text {-AUT (iliac) } \\
\text {-XEN (Bio-Oss) }\end{array}$ & Collagen membrane & 40 & 4 & $\begin{array}{l}\text { Material } \\
\text { donation }\end{array}$ \\
\hline 8 & Froum $2002 \$$ & ESP & 20 & $\begin{array}{l}\text {-ALL\$ } \\
\text {-SYN: BG (Biogran) }\end{array}$ & - & 20 & $6-8$ & $\begin{array}{l}\text { Commercial } \\
\text { support }\end{array}$ \\
\hline 9 & Froum $2004 \$$ & ESP & 20 & $\begin{array}{l}\text {-XEN (Osteograf R/N300) } \\
\text {-SYN: HA (Osteograf R/LD) }\end{array}$ & $\begin{array}{l}\text { ADMA or e-PTFE } \\
\text { membrane }\end{array}$ & 20 & $6-8$ & $\begin{array}{l}\text { Commercial } \\
\text { support }\end{array}$ \\
\hline 10 & Froum 2008 & SL & 24 & $\begin{array}{l}\text {-XEN (Bio-Oss) } \\
\text {-SYN: BCP (BoneCeramic) }\end{array}$ & Collagen membrane & NR & $6-8$ & $\begin{array}{l}\text { Commercial } \\
\text { support }\end{array}$ \\
\hline 11 & Garlini 2014 & SL & 10 & $\begin{array}{l}\text {-XEN (Bio-Oss) } \\
\text {-SYN: HA (Algipore) }\end{array}$ & Collagen membrane & 14 & $6-8$ & None \\
\hline 12 & Gholami 2012 & ESP & 24 & $\begin{array}{l}\text {-SYN: HA (NanoBone) } \\
\text {-SYN: HA (Algipore) }\end{array}$ & Collagen membrane & 24 & $6-8$ & NR \\
\hline 13 & Kotsakis $2014 \$$ & ESP & 24 & $\begin{array}{l}\text {-XEN (Bio-Oss)+collagen plug } \\
\text {-SYN: CP (NovaBone) }\end{array}$ & - & 16 & $5-6$ & $\begin{array}{l}\text { Material } \\
\text { donation \& } \\
\text { external grant }\end{array}$ \\
\hline 14 & Lee 2008 & SL & 52 & $\begin{array}{l}\text {-AUT (misc)+allograft (Puros) } \\
\text {-AUT (misc)+xenograft (Bio-Oss) } \\
\text {-AUT (misc)+SYN: FHA (C Graft) }\end{array}$ & - & 97 & $4-9$ & None \\
\hline 15 & Molly 2008 \$ & ESP & 36 & $\begin{array}{l}\text {-XEN (Bio-Oss) } \\
\text {-SYN: PLG (Fisiograft) } \\
\text {-SYN: HA (Biocoral) }\end{array}$ & e-PTFE membrane & NR & 6 & $\begin{array}{l}\text { Commercial } \\
\text { support }\end{array}$ \\
\hline 16 & Mordenfeld 2014 & LRA & 28 & $\begin{array}{l}\text {-AUT (mandible) } 10 \%+\text { xenograft (Bio- } \\
\text { Oss) } 90 \% \\
\text {-AUT (mandible) } 60 \%+\text { xenograft (Bio- } \\
\text { Oss) } 40 \% \\
\end{array}$ & Collagen membrane & 71 & 8.1 & $\begin{array}{l}\text { Material } \\
\text { donation }\end{array}$ \\
\hline 17 & Raghoebar 2005 & SL & 10 & $\begin{array}{l}\text {-AUT (iliac) } \\
\text {-AUT (iliac)+PRP }\end{array}$ & - & 30 & 3 & NR \\
\hline 18 & Rickert 2011 & SL & 24 & $\begin{array}{l}\text {-XEN (Bio-Oss)+stem cells } \\
\text {-AUT (mandible)+xenograft (Bio-Oss) }\end{array}$ & Collagen membrane & NR & $3-4$ & $\begin{array}{l}\text { Technical } \\
\text { assistance from } \\
\text { company }\end{array}$ \\
\hline 19 & Schmitt 2013 & SL & 45 & $\begin{array}{l}\text {-AUT (mandible) } \\
\text {-ALL (Puros) } \\
\text {-XEN (Bio-Oss) } \\
\text {-SYN: BCP (BoneCeramic) } \\
\end{array}$ & Collagen membrane & 94 & 5 & NR \\
\hline 20 & $\begin{array}{l}\text { Shirmohammadi } \\
2014\end{array}$ & SL & 20 & $\begin{array}{l}\text {-XEN (Bio-Oss)+autograft 20\% (misc) } \\
\text {-SYN: HA (Ostim)+autograft 20\% (misc) }\end{array}$ & Collagen membrane & & & None \\
\hline 21 & Szabo 2005 & SL/LRA & $40 / 10$ & $\begin{array}{l}\text {-AUT (iliac) } \\
\text {-SYN: b-TCP (Cerasorb) }\end{array}$ & - & 80 & 6 & NR \\
\hline 22 & Wagner $2012 \%$ & SL & 64 & $\begin{array}{l}\text {-AUT (jaws)+xenograft (Bio-Oss) } \\
\text {-SYN: MBCP (Tricos) }\end{array}$ & - & NR & 6 & $\begin{array}{l}\text { Commercial } \\
\text { support }\end{array}$ \\
\hline 23 & Wiltfang 2003 & SL & 45 & $\begin{array}{l}\text {-SYN: b-TCP (Curasan)+PRP } \\
\text {-SYN: b-TCP (Curasan) }\end{array}$ & - & NR & 6 & NR \\
\hline \multirow[t]{2}{*}{24} & Xavier 2014 & SL & 30 & $\begin{array}{l}\text {-ALL (FDBA) } \\
\text {-AUT (ramus) }\end{array}$ & Collagen membrane & 80 & 6 & NR \\
\hline & Parallel trials & & & & & & & \\
\hline 25 & $\begin{array}{l}\text { Calasans-Maia } \\
2013\end{array}$ & ESP & 20 & $\begin{array}{l}\text {-XEN (Bio-Oss) } \\
\text {-XEN (Osseus) }\end{array}$ & - & 20 & 6 & $\begin{array}{l}\text { Commercial } \\
\text { support }\end{array}$ \\
\hline 26 & Checci 2011 & ESP & 10 & $\begin{array}{l}\text {-SYN: HA (Sintlife) } \\
\text {-SYN: HA (Ostim) }\end{array}$ & Collagen sponge & 10 & 6 & None \\
\hline 27 & Cordaro 2011 & LRA & 22 & $\begin{array}{l}\text {-AUT (mandible) } \\
\text {-AUT+xenograft (Bio-Oss) }\end{array}$ & Collagen membrane & 55 & 4 & External grant \\
\hline
\end{tabular}




\begin{tabular}{|c|c|c|c|c|c|c|c|c|}
\hline 28 & de Freitas 2013 & LRA & 24 & $\begin{array}{l}\text {-AUT (mandible) } \\
\text {-GF: rhBMP-2/ACS }\end{array}$ & - & 62 & 6 & $\begin{array}{l}\text { External / } \\
\text { commercial } \\
\text { grants }\end{array}$ \\
\hline 29 & $\begin{array}{l}\text { Galindo-Moreno } \\
2011\end{array}$ & SL & 24 & $\begin{array}{l}\text {-AUT (maxilla) 50\%+xenograft (Bio-Oss) } \\
50 \% \\
\text {-AUT (maxilla) 20\%+xenograft (Bio-Oss) } \\
80 \%\end{array}$ & Collagen membrane & NR & 6 & External grants \\
\hline 30 & Hermund 2012 & SL & 20 & $\begin{array}{l}\text {-AUT (maxilla)+xenograft (Bio-Oss) } \\
\text {-AUT (maxilla)+xenograft (Bio- } \\
\text { Oss)+bone cells }\end{array}$ & Collagen membrane & 39 & 4 & $\begin{array}{l}\text { Commercial } \\
\text { support }\end{array}$ \\
\hline 31 & Jun 2014 & SL & 32 & $\begin{array}{l}\text {-AUT (extracted tooth) } \\
\text {-XEN (Bio-Oss) }\end{array}$ & - & 38 & 4 & $\begin{array}{l}\text { Government } \\
\text { grant }\end{array}$ \\
\hline 32 & $\begin{array}{l}\text { Koch 2010; } \\
\text { Stavropoulos } \\
2011 \\
\end{array}$ & SL & 20 & $\begin{array}{l}\text {-Autologous+b-TCP } \\
\text {-rhGDF-5/b-TCP }\end{array}$ & - & 66 & $3-4$ & $\begin{array}{l}\text { Commercial } \\
\text { support }\end{array}$ \\
\hline 33 & $\begin{array}{l}\text { Kuhl 2012; Kuhl } \\
2013\end{array}$ & SL & 23 & $\begin{array}{l}\text {-AUT (mandible) } \\
\text {-AUT (mandible)+SYN: BCP } \\
\text { (BoneCeramic) } \\
\text {-AUT (mandible)+SYN: BCP (Cerasorb) }\end{array}$ & - & - & - & Internal \\
\hline 34 & Kurkcu 2012 & SL & 23 & $\begin{array}{l}\text {-XEN (BonePlus-xs) } \\
\text {-SYN: BCP (BoneCeramic) }\end{array}$ & - & 51 & 6.5 & NR \\
\hline 35 & $\begin{array}{l}\text { Mardas 2010; } \\
\text { Mardas 2011; } \\
\text { Patel 2013 }\end{array}$ & ESP & 26 & $\begin{array}{l}\text {-XEN (Bio-Oss) } \\
\text {-SYN: BCP (BoneCeramic) }\end{array}$ & Collagen membrane & - & - & $\begin{array}{l}\text { Material } \\
\text { donation }\end{array}$ \\
\hline 36 & Meijndert 2005 \# & LRA & 10 & $\begin{array}{l}\text {-AUT (chin) } \\
\text {-XEN (Bio-Oss) }\end{array}$ & Collagen membrane & NR & $3-6$ & $\begin{array}{l}\text { Commercial } \\
\text { support }\end{array}$ \\
\hline 37 & Meijndert 2008 \# & ESP & 62 & $\begin{array}{l}\text {-AUT (chin) } \\
\text {-XEN (Bio-Oss) }\end{array}$ & Collagen membrane & NR & $3-6$ & $\begin{array}{l}\text { Commercial } \\
\text { support }\end{array}$ \\
\hline 38 & Piattelli 2002 & ESP & 24 & $\begin{array}{l}\text {-AUT (upper/lower jaw) } \\
\text {-XEN (Bio-Oss) }\end{array}$ & - & 24 & $3-6$ & External grant \\
\hline 39 & Pikdoken 2011 & SL & 24 & $\begin{array}{l}\text {-AUT (sinus) } 20 \%+\text { xenograft (NuOss) } \\
80 \% \\
\text {-XEN (NuOss) } 80 \%\end{array}$ & Collagen membrane & NR & 4 & NR \\
\hline 40 & Tosta 2013 & SL & 30 & $\begin{array}{l}\text {-AUT (maxilla) } \\
\text {-SYN: BCP (BoneCeramic) }\end{array}$ & Collagen membrane & NR & 9 & Internal \\
\hline 41 & Wood 2012 & ESP & 33 & $\begin{array}{l}\text {-ALL (DFDBA) } \\
\text {-ALL (FDBA) }\end{array}$ & Collagen membrane & - & - & $\begin{array}{l}\text { Material } \\
\text { donation }\end{array}$ \\
\hline
\end{tabular}

ADMA, acellular dermal matrix allograft; ALL, allograft; AUT, autograft; BC, bone cyst; BCP, biphasic calcium phosphate; b-TCP, beta-tricalcium phosphate; CS, calcium sulfate; DFDBA, demineralized freeze-dried bone allograft; e-PTFE, expanded polytetrafluoroethylene; ESP, extraction socket preservation; FHA, fluorohydroxyapatite; GF, growth factor; HA, hydroxyapatite; LRA, lateral ridge augmentation; MBCP, microporous and macroporous biphasic calcium phosphate; mos, months; NR, not reported; PLG, Poly-Lactide-co-Glycolide polymer; PRP, platelet rich plasma; rhBMP-2/ACS, recombinant human bone morphogenetic protein-2 delivered on an Absorbable Collagen Sponge; rhGDF-5/b-TCP, recombinant human growth/differentiation factor- 5 coated onto a $\beta$-tricalciumphosphate; SYN, synthetic bone substitute; SL, sinus lift; VRA, vertical ridge augmentation; XEN, xenograft. 
Appendix 6. Outcomes reported from the 41 trials included in the systematic review.

\begin{tabular}{|c|c|c|c|c|}
\hline $\mathbf{N r}$ & Study & $\begin{array}{l}\text { Raw } \\
\text { data }\end{array}$ & Bone outcome (follow-up) & Outcome (follow-up) \\
\hline & Cluster trials & & & \\
\hline 1 & Bettega 2009 & - & $\begin{array}{l}\text { Bone height \& density (NR mos) } \\
\text { Histomorphometry ( } 6 \text { mos) }\end{array}$ & Implant survival (12 mos post-op) \\
\hline 2 & Cordaro 2008 & - & Histomorphometry (6-8 mos) & - \\
\hline 3 & Corinaldesi 2013 & - & $\begin{array}{l}\text { Bone height ( } 4 \text { mos) } \\
\text { Histomorphometry ( } 4 \text { mos) }\end{array}$ & - \\
\hline 4 & Crespi 2009a \$ & - & $\begin{array}{l}\text { Bone height \& density (3 mos) } \\
\text { Histomorphometry (3 mos) }\end{array}$ & - \\
\hline 5 & Crespi 2009b & - & $\begin{array}{l}\text { Histomorphometry (5 mos) } \\
\text { Gene expression profiling ( } 5 \text { mos })\end{array}$ & - \\
\hline 6 & Crespi $2011 \$$ & - & Histomorphometry (4 mos) & - \\
\hline 7 & Felice 2008 & - & Bone height ( 4 mos) & - \\
\hline 8 & Froum $2002 \$$ & $\sqrt{ }$ & Histomorphometry (6-8 mos) & - \\
\hline 9 & Froum $2004 \$$ & $\sqrt{ }$ & Histomorphometry (6-8 mos) & - \\
\hline 10 & Froum 2008 & $\sqrt{ }$ & Histomorphometry (6-8 mos) & - \\
\hline 11 & Garlini 2014 & $\sqrt{ }$ & Histomorphometry (6-8 mos) & - \\
\hline 12 & Gholami 2012 & - & $\begin{array}{l}\text { Bone width (6-8 mos) } \\
\text { Histomorphometry (6-8 mos) }\end{array}$ & - \\
\hline 13 & Kotsakis 2014 \$ & - & Bone width \& height (5 mos) & $\begin{array}{l}\text { Implant primary stability (NR mos) } \\
\text { Implant success (20 mos post-op) }\end{array}$ \\
\hline 14 & Lee 2008 & $\sqrt{ }$ & Histomorphometry (4-9 mos) & - \\
\hline 15 & Molly $2008 \$$ & - & Histomorphometry (6 mos) & Insertion torque and mobility of the implants (NR mos) \\
\hline 16 & Mordenfeld 2014 & - & \begin{tabular}{|l} 
Bone width (7.5 mos) \\
Histomorphometry (8.1 mos)
\end{tabular} & Implant failure (11.4 mos post-op) \\
\hline 17 & Raghoebar 2005 & - & $\begin{array}{l}\text { Bone density (3 mos) } \\
\text { Histomorphometry (3 mos) }\end{array}$ & $\begin{array}{l}\text { Implant failure (20.2 mos post-op) } \\
\text { Implant compications (20.2 mos post-op) }\end{array}$ \\
\hline 18 & Rickert 2011 & $\sqrt{ }$ & Histomorphometry (3.4 mos) & Implant failure (3 mos post-op) \\
\hline 19 & Schmitt 2013 & - & $\begin{array}{l}\text { Bone height (NR mos) } \\
\text { Histomorphometry (5 mos) }\end{array}$ & - \\
\hline 20 & Shirmohammadi 2014 & $\sqrt{ }$ & $\begin{array}{l}\text { Histomorphometry ( } 5 \text { mos) } \\
\text { Bone height and density ( } 5 \text { mos) }\end{array}$ & \\
\hline 21 & Szabo 2005 & $\sqrt{ }$ & Histomorphometry (6 mos) & Implant failure (6 mos post-op) \\
\hline 22 & Wagner $2012 \%$ & - & Histomorphometry (6 mos) & Implant stability (12 mos post-op) \\
\hline 23 & Wiltfang 2003 & - & Histomorphometry (6 mos) & - \\
\hline \multirow[t]{2}{*}{24} & Xavier 2014 & $\sqrt{ }$ & Histomorphometry (6 mos) & Implant failure (6 mos post-op) \\
\hline & Parallel trials & & & \\
\hline 25 & Calasans-Maia 2013 & $\sqrt{ }$ & Histomorphometry (6 mos) & - \\
\hline 26 & Checci 2011 & - & Histomorphometry (6 mos) & - \\
\hline 27 & Cordaro 2011 & - & Bone width (24 mos after imp loading) & - \\
\hline 28 & de Freitas 2013 & - & Bone width (6 mos) & Implant success (6 mos post-op) \\
\hline 29 & Galindo-Moreno 2011 & - & Histomorphometry (6 mos) & - \\
\hline 30 & Hermund 2012 & - & $\begin{array}{l}\text { Bone height ( } 4 \text { mos) } \\
\text { Histomorphometry (4 mos) }\end{array}$ & - \\
\hline 31 & Jun 2014 & - & $\begin{array}{l}\text { Bone height \& density ( } 4 \text { mos) } \\
\text { Sinus membrane thickness ( } 4 \text { mos) } \\
\text { Histomorphometry ( } 4 \text { mos) }\end{array}$ & Implant primary stability( 4 mos post-op) \\
\hline 32 & $\begin{array}{l}\text { Koch 2010; Stavropoulos } \\
2011\end{array}$ & - & Histomorphometry (3-4 mos) & - \\
\hline 33 & Kuhl 2012; Kuhl 2013 & - & Bone density \& volume (5 mos) & - \\
\hline 34 & Kurkcu 2012 & - & Histomorphometry (6.5 mos) & - \\
\hline 35 & $\begin{array}{l}\text { Mardas 2010; Mardas 2011; } \\
\text { Patel } 2013\end{array}$ & - & $\begin{array}{l}\text { Periodontal health of neighbouring teeth (8 mos) } \\
\text { Bone width, height, and radioopacity (8 mos) } \\
\text { Residual bone defects (NR mos) } \\
\text { Resistance of bone to trephination (NR mos) }\end{array}$ & $\begin{array}{l}\text { Peri-implant bone height (12 mos post-loading) } \\
\text { Implant failure (12 mos post-loading) }\end{array}$ \\
\hline 36 & Meijndert 2005 \# & - & $\begin{array}{l}\text { Histomorphometry (3-6 mos) } \\
\text { Periodontal health (NR mos) }\end{array}$ & - \\
\hline 37 & Meijndert 2008 \# & - & $\begin{array}{l}\text { Bone height (21-24 mos post-op) } \\
\text { Periodontal health (21-24 mos post-op) }\end{array}$ & \\
\hline 38 & Piattelli 2002 & - & Microvessel density (3-6 mos) & - \\
\hline 39 & Pikdoken 2011 & - & $\begin{array}{l}\text { Scintigraphic osteoblastic activity (4 mos) } \\
\text { Histomorphometry ( } 4 \text { mos) }\end{array}$ & - \\
\hline 40 & Tosta 2013 & - & Histomorphometry (9 mos) & Implant failure (12 mos post-op) \\
\hline 41 & Wood 2012 & - & $\begin{array}{l}\text { Histomorphometry (6-7 mos) } \\
\text { Bone width and height }\end{array}$ & - \\
\hline
\end{tabular}
mos, monts; NR, not reported. 
Appendix 7. Details of the risk of bias assessment for each of the 41 included trials in the systematic review.

\begin{tabular}{|c|c|c|c|c|c|c|c|c|}
\hline $\mathrm{Nr}$ & Trial & Sequence generation & $\begin{array}{l}\text { Allocation } \\
\text { concealment }\end{array}$ & $\begin{array}{l}\text { Blinding of } \\
\text { participants, personnel }\end{array}$ & $\begin{array}{l}\text { Blinding of outcome } \\
\text { assessors }\end{array}$ & Incomplete outcome data & Selective outcome reporting & Other sources of bias \\
\hline 1 & Bettega 2009 & $\begin{array}{l}\text { (+) - "The iliac crest graft was } \\
\text { then harvested, and the } \\
\text { destination for the two } \\
\text { techniques (traditional versus } \\
\text { APC) was chosen through a } \\
\text { two-element randomization } \\
\text { table" }\end{array}$ & (?) - no mention. & $\begin{array}{l}(+) \text { - blinding of the } \\
\text { operator not possible; } \\
\text { outcome assessment } \\
\text { safeguarded. }\end{array}$ & $\begin{array}{l}\text { (+) - "All radiological } \\
\text { images were read } \\
\text { blindly by a } \\
\text { radiologist.....Histologi } \\
\text { c bone assessment was } \\
\text { performed blindly by } \\
\text { the histologist." }\end{array}$ & $\begin{array}{l}(+) \text { - No drop-outs or patient } \\
\text { losses are reported. }\end{array}$ & $\begin{array}{l}\text { (?) - It is difficult to judge } \\
\text { whether selective reporting is a } \\
\text { problem, as no protocol exists. }\end{array}$ & $\begin{array}{l}\text { (?) - residual bias } \\
\text { cannot be excluded. }\end{array}$ \\
\hline 2 & $\begin{array}{l}\text { Calasans-Maia } \\
2013\end{array}$ & $\begin{array}{l}(+) \text { - unclear randomization; } \\
\text { judged that the risk of bias } \\
\text { could be classified as low: "The } \\
\text { volunteer subjects were } \\
\text { randomly assigned to the tests } \\
\text { groups using an envelope } \\
\text { system distribution provided } \\
\text { by the principal investigator." }\end{array}$ & $\begin{array}{l}(+) \text { - same as } \\
\text { sequence generation. }\end{array}$ & $\begin{array}{l}(+) \text { - blinding of the } \\
\text { operator not possible; } \\
\text { outcome assessment } \\
\text { safeguarded. }\end{array}$ & $\begin{array}{l}(+)-“ \ldots, \text { which were } \\
\text { assessed by a single } \\
\text { observer blinded to } \\
\text { the clinical data". }\end{array}$ & $\begin{array}{l}(+) \text { - No drop-outs or patient } \\
\text { losses are reported. }\end{array}$ & $\begin{array}{l}\text { (?) - It is difficult to judge } \\
\text { whether selective reporting is a } \\
\text { problem, as no protocol exists. }\end{array}$ & $\begin{array}{l}(+) \text { - smoking and } \\
\text { systemic diseases } \\
\text { covered from the } \\
\text { exclusion criteria. }\end{array}$ \\
\hline 3 & Checci 2011 & $\begin{array}{l}\text { (?) - "At the time of extraction, } \\
\text { the patients were randomly } \\
\text { assigned to the test group (T) } \\
\text { or the control group (C)." }\end{array}$ & (?) - no mention. & $\begin{array}{l}(+) \text { - blinding of the } \\
\text { operator not possible; } \\
\text { outcome assessment } \\
\text { safeguarded. }\end{array}$ & $\begin{array}{l}+(+ \text { - "Two evaluators } \\
\text { performed the } \\
\text { histopathological } \\
\text { evaluation blindly, } \\
\text { using a light polarized } \\
\text { microscope (Nikon } \\
\text { Eclipse E800M, Tokyo, } \\
\text { Japan),.." }\end{array}$ & $\begin{array}{l}(+) \text { - No drop-outs or patient } \\
\text { losses are reported. }\end{array}$ & $\begin{array}{l}\text { (?) - It is difficult to judge } \\
\text { whether selective reporting is a } \\
\text { problem, as no protocol exists. }\end{array}$ & $\begin{array}{l}(+) \text { - smoking and } \\
\text { systemic diseases } \\
\text { covered from the } \\
\text { exclusion criteria. }\end{array}$ \\
\hline 4 & Cordaro 2008 & $\begin{array}{l}\text { (?) - randomization unclear } \\
\text { (see allocation concealment). }\end{array}$ & $\begin{array}{l}+(+ \text { - probably } \\
\text { adequate: "The } \\
\text { randomization } \\
\text { envelope was opened } \\
\text { and the patient could } \\
\text { be allocated to either } \\
\text { the test or control } \\
\text { group only after } \\
\text { completion of the } \\
\text { elevation of the sinus } \\
\text { membrane; in cases } \\
\text { of bilateral sinus } \\
\text { augmentation, each } \\
\text { sinus was } \\
\text { independently } \\
\text { randomized to either } \\
\text { the test or control } \\
\text { group." }\end{array}$ & $\begin{array}{l}\text { (?) - blinding of the } \\
\text { operator not possible; } \\
\text { outcome assessment } \\
\text { unclear. }\end{array}$ & (?) - no mention. & $\begin{array}{l}(-) \text { - Variation in the number of } \\
\text { available samples between } \\
\text { groups without accounting for } \\
\text { it in the results: "Measurable } \\
\text { specimens were available from } \\
14 \text { out of } 25 \text { sinuses for the } \\
\text { test group ( } 56 \% \text { of the sites) } \\
\text { and in } 18 \text { out of } 23 \text { sinuses in } \\
\text { the control group ( } 81.8 \% \text { of } \\
\text { the sites). }\end{array}$ & $\begin{array}{l}\text { (?) - It is difficult to judge } \\
\text { whether selective reporting is a } \\
\text { problem, as no protocol exists. }\end{array}$ & $\begin{array}{l}(-) \text { - clustered } \\
\text { measurements } \\
\text { treated correctly, but } \\
\text { effect of smoking not } \\
\text { addressed. }\end{array}$ \\
\hline 5 & Cordaro 2011 & $\begin{array}{l}(+) \text { - "Randomization } \\
\text { envelopes were generated by } \\
\text { an independent statistician } \\
\text { with the blocks method and } \\
\text { kept by an administrative } \\
\text { employee not involved in the } \\
\text { study." }\end{array}$ & $\begin{array}{l}(+) \text { - allocation } \\
\text { concealment } \\
\text { adequate (same as } \\
\text { sequence } \\
\text { generation). }\end{array}$ & $\begin{array}{l}\text { (?) - blinding of the } \\
\text { operator not possible; } \\
\text { outcome assessment } \\
\text { unclear. }\end{array}$ & (?) - no mention. & $\begin{array}{l}(+) \text { - No drop-outs or patient } \\
\text { losses are reported. }\end{array}$ & $\begin{array}{l}\text { (?) - It is difficult to judge } \\
\text { whether selective reporting is a } \\
\text { problem, as no protocol exists. }\end{array}$ & $\begin{array}{l}(-) \text { - smoking not } \\
\text { taken into account, } \\
\text { and no raw data } \\
\text { given. }\end{array}$ \\
\hline
\end{tabular}




\begin{tabular}{|c|c|c|c|c|c|c|c|c|}
\hline 6 & $\begin{array}{l}\text { Corinaldesi } \\
2013\end{array}$ & $\begin{array}{l}\text { (?) - randomization unclear: } \\
\text { "After the sinus membrane had } \\
\text { been dissected and raised, } \\
\text { block randomisation was used } \\
\text { to designate a test side and a } \\
\text { control side for each patient." }\end{array}$ & (?) - no mention. & $\begin{array}{l}\text { (?) - blinding of the } \\
\text { operator not possible; } \\
\text { outcome assessment } \\
\text { unclear. }\end{array}$ & (?) - no mention. & $\begin{array}{l}(+) \text { - No drop-outs or patient } \\
\text { losses are reported. }\end{array}$ & $\begin{array}{l}\text { (?) - It is difficult to judge } \\
\text { whether selective reporting is a } \\
\text { problem, as no protocol exists. }\end{array}$ & $\begin{array}{l}(-) \text { - raw data are } \\
\text { given for each patient, } \\
\text { but smoking among } \\
\text { patients not reported. }\end{array}$ \\
\hline 7 & Crespi 2009a & $\begin{array}{l}\text { (-) - quasi-randomization } \\
\text { (right/left mouth side): } \\
\text { "Fifteen sockets, all on the } \\
\text { right side of the mouth, } \\
\text { received MHA (Ca10- } \\
\text { xMgx(PO4)6(OH)2) in granular } \\
\text { form (SintLife, Finceramica) } \\
\text { (MHA group); 15 sockets on } \\
\text { the left side received xenogenic } \\
\text { corticocancellous porcine bone } \\
\text { (Tecnoss) (PB group); and 15 } \\
\text { unfilled random sockets were } \\
\text { considered as control (C) } \\
\text { group." }\end{array}$ & (?) - no mention. & $\begin{array}{l}(+) \text { - blinding of the } \\
\text { operator not possible; } \\
\text { outcome assessment } \\
\text { safeguarded. }\end{array}$ & $\begin{array}{l}(+)-\text { "A masked } \\
\text { examinermeasured the } \\
\text { bone level changes } \\
\text { 3months after the } \\
\text { tooth extractions (Fig. } \\
\text { 2)." }\end{array}$ & $\begin{array}{l}(+) \text { - No drop-outs or patient } \\
\text { losses are reported. }\end{array}$ & $\begin{array}{l}\text { (?) - It is difficult to judge } \\
\text { whether selective reporting is a } \\
\text { problem, as no protocol exists. }\end{array}$ & $\begin{array}{l}(+) \text { - raw data are } \\
\text { given for each patient } \\
\text { (smoking and } \\
\text { systemic diseases } \\
\text { covered from the } \\
\text { exclusion criteria). }\end{array}$ \\
\hline 8 & Crespi 2009b & $\begin{array}{l}\text { (?) - randomization unclear: } \\
\text { "According to the split-mouth } \\
\text { design, all patients received } \\
\text { autologous bone particles } \\
\text { harvested from the ascending } \\
\text { ramus of the mandible22,23 in } \\
\text { a randomly assigned maxillary } \\
\text { sinus" }\end{array}$ & (?) - no mention. & $\begin{array}{l}\text { (?) - blinding of the } \\
\text { operator not possible; } \\
\text { outcome assessment } \\
\text { unclear. }\end{array}$ & (?) - no mention. & $\begin{array}{l}(+) \text { - No drop-outs or patient } \\
\text { losses are reported. }\end{array}$ & $\begin{array}{l}(-) \text { - It is difficult to judge } \\
\text { whether selective reporting is a } \\
\text { problem, as no protocol exists. } \\
\text { Data not adequately reported } \\
\text { to allow processing. }\end{array}$ & $\begin{array}{l}(-) \text { - effect of smoking } \\
\text { was not taken into } \\
\text { account and no raw } \\
\text { data reported. }\end{array}$ \\
\hline 9 & Crespi 2011 & $\begin{array}{l}(-) \text { - quasi-randomization } \\
\text { (right/left mouth side): "Split- } \\
\text { mouth treatment was } \\
\text { performed: } 15 \text { sockets in the } \\
\text { right side of the jaw received } \\
\text { MHA (Ca10- } \\
\text { xMgx[PO4]6[OH]2) available in } \\
\text { granule form, } \dagger 15 \text { sockets in } \\
\text { the left side received CS, } \text { and } \\
15 \text { unfilled random sockets } \\
\text { were considered the control } \\
\text { (C) group" }\end{array}$ & (?) - no mention. & $\begin{array}{l}\text { (?) - blinding of the } \\
\text { operator not possible; } \\
\text { outcome assessment } \\
\text { unclear. }\end{array}$ & (?) - no mention. & $\begin{array}{l}(+) \text { - No drop-outs or patient } \\
\text { losses are reported. }\end{array}$ & $\begin{array}{l}\text { (?) - It is difficult to judge } \\
\text { whether selective reporting is a } \\
\text { problem, as no protocol exists. }\end{array}$ & $\begin{array}{l}(-) \text { - clustered } \\
\text { measurements } \\
\text { treated as } \\
\text { independent and no } \\
\text { raw data given. }\end{array}$ \\
\hline 10 & $\begin{array}{l}\text { de Freitas } \\
2013\end{array}$ & $\begin{array}{l}(+)-\text { "Twenty-four small paper } \\
\text { cards were consecutively } \\
\text { marked as test }(\mathrm{n}=12) \text { or } \\
\text { control }(\mathrm{n}=12), \text { folded and } \\
\text { placed in a dark container for } \\
\text { allocation concealment." }\end{array}$ & $\begin{array}{l}(+)-\text { "An assistant } \\
\text { not involved in the } \\
\text { study was then asked } \\
\text { to draw one paper } \\
\text { from the container." }\end{array}$ & $\begin{array}{l}(+) \text { - blinding of the } \\
\text { operator not possible; } \\
\text { outcome assessment } \\
\text { safeguarded. }\end{array}$ & $\begin{array}{l}(+) \text { - "Radiographic } \\
\text { recordings were } \\
\text { performed by a } \\
\text { masked examiner } \\
\text { (RSN)." }\end{array}$ & $\begin{array}{l}(+) \text { - No drop-outs or patient } \\
\text { losses are reported. }\end{array}$ & $\begin{array}{l}\text { (?) - It is difficult to judge } \\
\text { whether selective reporting is a } \\
\text { problem, as no protocol exists. }\end{array}$ & $\begin{array}{l}(+) \text { - smoking and } \\
\text { systemic diseases } \\
\text { covered from the } \\
\text { exclusion criteria. }\end{array}$ \\
\hline 11 & Felice 2008 & $\begin{array}{l}(+)-\text { "A computer-generated } \\
\text { restricted randomisation list } \\
\text { was created by an office of the } \\
\text { S. Orsola-Malpighi hospital. } \\
\text { None of the investigators were } \\
\text { aware of the randomisation } \\
\text { sequence." }\end{array}$ & $\begin{array}{l}(+)-\text { "The } \\
\text { randomised codes } \\
\text { were enclosed in } \\
\text { sequentially } \\
\text { numbered, identical, } \\
\text { opaque, sealed } \\
\text { envelopes. Envelopes }\end{array}$ & $\begin{array}{l}(+) \text { - blinding of the } \\
\text { operator not possible; } \\
\text { outcome assessment } \\
\text { safeguarded. }\end{array}$ & $\begin{array}{l}(+)-\text { "Two dentists (Dr } \\
\text { Fabio Rossi and Dr } \\
\text { Gerardo Pellegrino) } \\
\text { not involved in the } \\
\text { treatment of the } \\
\text { patients made all the } \\
\text { clinical and }\end{array}$ & $\begin{array}{l}(+)-" . . . \text { no dropout, exclusion } \\
\text { or deviation from the protocol } \\
\text { occurred up to the insertion of } \\
\text { the final prosthesis." }\end{array}$ & $\begin{array}{l}(+)-\text { "...no dropout, exclusion or } \\
\text { deviation from the protocol } \\
\text { occurred up to the insertion of } \\
\text { the final prosthesis." }\end{array}$ & $\begin{array}{l}(-) \text { - clustered } \\
\text { measurements } \\
\text { treated correctly with } \\
\text { paired t-tests, but } \\
\text { effect of smoking not } \\
\text { addressed. }\end{array}$ \\
\hline
\end{tabular}




\begin{tabular}{|c|c|c|c|c|c|c|c|c|}
\hline & & & $\begin{array}{l}\text { were opened } \\
\text { sequentially one day } \\
\text { before surgery." }\end{array}$ & & $\begin{array}{l}\text { radiographic } \\
\text { assessments without } \\
\text { knowledge of group } \\
\text { allocation, therefore, } \\
\text { outcome assessors } \\
\text { were blind to these } \\
\text { assessments. A } \\
\text { biostatistician with } \\
\text { expertise in dentistry } \\
\text { analysed the data, } \\
\text { without knowing the } \\
\text { group codes." }\end{array}$ & & & \\
\hline 12 & Froum 2002 & $\begin{array}{l}(+) \text { - assumed to be adequate: } \\
\text { "Treatment selection was then } \\
\text { made randomly from sealed } \\
\text { envelopes prepared by a } \\
\text { statistician." }\end{array}$ & $\begin{array}{l}(+) \text { - assumed to be } \\
\text { adequate (same as } \\
\text { sequence } \\
\text { generation). }\end{array}$ & $\begin{array}{l}(+) \text { - blinding of the } \\
\text { operator not possible; } \\
\text { outcome assessment } \\
\text { safeguarded. }\end{array}$ & $\begin{array}{l}(+)-\text { "...measurements } \\
\text { were performed by an } \\
\text { investigator who had } \\
\text { no knowledge of the } \\
\text { treatment rendered." }\end{array}$ & $\begin{array}{l}(+) \text { - No drop-outs or patient } \\
\text { losses are reported. }\end{array}$ & $\begin{array}{l}\text { (?) - It is difficult to judge } \\
\text { whether selective reporting is a } \\
\text { problem, as no protocol exists. }\end{array}$ & $\begin{array}{l}\text { (+) - raw data are } \\
\text { given for each patient } \\
\text { including patient's } \\
\text { gender (smoking and } \\
\text { systemic diseases } \\
\text { covered from the } \\
\text { exclusion criteria). }\end{array}$ \\
\hline 13 & Froum 2004 & $\begin{array}{l}\text { (+) - assumed to be adequate: } \\
\text { "Treatment selection was then } \\
\text { made randomly from sealed } \\
\text { envelopes prepared by a } \\
\text { statistician." }\end{array}$ & $\begin{array}{l}(+) \text { - assumed to be } \\
\text { adequate (same as } \\
\text { sequence } \\
\text { generation). }\end{array}$ & $\begin{array}{l}(+) \text { - blinding of the } \\
\text { operator not possible; } \\
\text { outcome assessment } \\
\text { safeguarded. }\end{array}$ & $\begin{array}{l}(+) \text { - "The processing } \\
\text { and } \\
\text { histomorphometric } \\
\text { measurements were } \\
\text { performed by an } \\
\text { investigator who had } \\
\text { no knowledge of the } \\
\text { treatment rendered." }\end{array}$ & $\begin{array}{l}(+) \text { - No drop-outs or patient } \\
\text { losses are reported. }\end{array}$ & $\begin{array}{l}\text { (?) - It is difficult to judge } \\
\text { whether selective reporting is a } \\
\text { problem, as no protocol exists. }\end{array}$ & $\begin{array}{l}(+) \text { - raw data are } \\
\text { given for each patient } \\
\text { including patient's } \\
\text { gender and } \\
\text { membrane use } \\
\text { (smoking and } \\
\text { systemic diseases } \\
\text { covered from the } \\
\text { exclusion criteria). } \\
\end{array}$ \\
\hline 14 & Froum 2008 & $\begin{array}{l}(+) \text { - The sinus membrane was } \\
\text { then elevated across the floor } \\
\text { and up the medial wall. BCP } \\
\text { was placed in one subantral } \\
\text { compartment and ABBM was } \\
\text { placed in the contralateral } \\
\text { subantral compartment, as } \\
\text { determined by a computer- } \\
\text { generated randomized code." }\end{array}$ & (?) - no mention. & $\begin{array}{l}\text { (?) - blinding of the } \\
\text { operator not possible; } \\
\text { outcome assessment } \\
\text { unclear. }\end{array}$ & (?) - no mention. & $\begin{array}{l}\text { (+) - dropout judged not to be } \\
\text { substantial or related to the } \\
\text { interventions: "One withdrew } \\
\text { for financial reasons, one } \\
\text { because of an inability to } \\
\text { obtain cores within the study } \\
\text { time protocol, and one because } \\
\text { of an infection that required } \\
\text { re-entry and debridement } \\
\text { prior to the time required for } \\
\text { core harvesting." }\end{array}$ & $\begin{array}{l}\text { (?) - It is difficult to judge } \\
\text { whether selective reporting is a } \\
\text { problem, as no protocol exists. }\end{array}$ & $\begin{array}{l}(-) \text { - raw data are } \\
\text { given for each patient, } \\
\text { but smoking among } \\
\text { patients not reported. }\end{array}$ \\
\hline 15 & $\begin{array}{l}\text { Galindo- } \\
\text { Moreno } 2011\end{array}$ & $\begin{array}{l}\text { (?) - "Patients were randomly } \\
\text { assigned to the two groups } \\
(\mathrm{n}=14 \text { each).. }\end{array}$ & (?) - no mention. & $\begin{array}{l}(+) \text { - blinding of the } \\
\text { operator not possible; } \\
\text { outcome assessment } \\
\text { safeguarded. }\end{array}$ & $\begin{array}{l}(+) \text { - "Histological, } \\
\text { histomorphometrical, } \\
\text { and } \\
\text { immunohistochemical } \\
\text { analyses were } \\
\text { conducted by an } \\
\text { experienced, masked } \\
\text { examiner (F.O.)." }\end{array}$ & $\begin{array}{l}(+) \text { - No drop-outs or patient } \\
\text { losses are reported. }\end{array}$ & $\begin{array}{l}\text { (?) - It is difficult to judge } \\
\text { whether selective reporting is a } \\
\text { problem, as no protocol exists. }\end{array}$ & $\begin{array}{l}(-) \text { - smoking not } \\
\text { taken into account, } \\
\text { and no raw data } \\
\text { given. }\end{array}$ \\
\hline 16 & Garlini 2014 & $\begin{array}{l}\text { (?) - "A randomized clinical } \\
\text { study with a split-mouth } \\
\text { design" }\end{array}$ & (?) - no mention. & $\begin{array}{l}\text { (?) - blinding of the } \\
\text { operator not possible; } \\
\text { outcome assessment } \\
\text { unclear. }\end{array}$ & (?) - no mention. & $\begin{array}{l}(+) \text { - No drop-outs or patient } \\
\text { losses are reported. }\end{array}$ & $\begin{array}{l}\text { (?) - It is difficult to judge } \\
\text { whether selective reporting is a } \\
\text { problem, as no protocol exists. }\end{array}$ & $\begin{array}{l}(-) \text { - effect of smoking } \\
\text { was not taken into } \\
\text { account and smoking } \\
\text { status not reported in } \\
\text { raw data. }\end{array}$ \\
\hline
\end{tabular}




\begin{tabular}{|c|c|c|c|c|c|c|c|c|}
\hline 17 & Gholami 2012 & $\begin{array}{l}(+) \text { - "Fifteen symmetrical pairs } \\
\text { were randomly selected, using } \\
\text { a random number table, as one } \\
\text { side of the mouth in each } \\
\text { patient.." }\end{array}$ & (?) - no mention. & $\begin{array}{l}(+) \text { - blinding of the } \\
\text { operator not possible; } \\
\text { outcome assessment } \\
\text { safeguarded. }\end{array}$ & $\begin{array}{l}(+)-\text { The sections were } \\
\text { analyzed by an } \\
\text { examiner masked to } \\
\text { the type of treatment." }\end{array}$ & $\begin{array}{l}(+)-2 \text { missing patients; due to } \\
\text { the trial's design, losses are } \\
\text { balanced. }\end{array}$ & $\begin{array}{l}\text { (?) - It is difficult to judge } \\
\text { whether selective reporting is a } \\
\text { problem, as no protocol exists. }\end{array}$ & $\begin{array}{l}(-) \text { - smoking not } \\
\text { taken into account, } \\
\text { and no raw data } \\
\text { given. }\end{array}$ \\
\hline 18 & Hermund 2012 & $\begin{array}{l}(+) \text { - "and then the patients } \\
\text { were randomly assigned to a } \\
\text { control }(\mathrm{n}=10) \text { or test group } \\
(\mathrm{n}=10) \text { using a blinded draw } \\
\text { from a bag containing } 20 \\
\text { identical pieces of paper with } \\
\text { the group name printed on } \\
\text { them" }\end{array}$ & (?) - no mention. & $\begin{array}{l}(+) \text { - blinding of the } \\
\text { operator not possible; } \\
\text { outcome assessment } \\
\text { safeguarded. }\end{array}$ & $\begin{array}{l}(+) \text { - "A single, } \\
\text { previously calibrated } \\
\text { examiner (NUH), who } \\
\text { was blinded to } \\
\text { treatment group, } \\
\text { evaluated all } \\
\text { specimens." }\end{array}$ & $\begin{array}{l}(+) \text { - minor missing samples } \\
\text { from some implant } \\
\text { positions/judged to be } \\
\text { insignificant. }\end{array}$ & $\begin{array}{l}\text { (?) - It is difficult to judge } \\
\text { whether selective reporting is a } \\
\text { problem, as no protocol exists. }\end{array}$ & $\begin{array}{l}(-) \text { - smoking not } \\
\text { taken into account, } \\
\text { and no raw data } \\
\text { given. }\end{array}$ \\
\hline 19 & Jun 2014 & $\begin{array}{l}(+)-\text {-The allocation of the } \\
\text { participants was done by } \\
\text { random sequence generator." }\end{array}$ & (?) - no mention. & $\begin{array}{l}(+) \text { - blinding of the } \\
\text { operator not possible; } \\
\text { outcome assessment } \\
\text { safeguarded. }\end{array}$ & $\begin{array}{l}+) \text { - "This } \\
\text { measurement was } \\
\text { performed by one oral } \\
\text { and maxillofacial } \\
\text { surgeon who does not } \\
\text { know the control/ } \\
\text { experimental group." }\end{array}$ & $\begin{array}{l}(+) \text { - equal number of drop-out } \\
\text { for the two groups; judged to } \\
\text { be insignificant. }\end{array}$ & $\begin{array}{l}\text { (?) - It is difficult to judge } \\
\text { whether selective reporting is a } \\
\text { problem, as no protocol exists. }\end{array}$ & $\begin{array}{l}(-) \text { - smoking not } \\
\text { taken into account, } \\
\text { and no raw data } \\
\text { given. }\end{array}$ \\
\hline 20 & $\begin{array}{l}\text { Koch 2010; } \\
\text { Stavropoulos } \\
2011\end{array}$ & $\begin{array}{l}(+)-\text { "For sinus floor } \\
\text { augmentation, three treatment } \\
\text { groups were randomized } \\
\text { according to a computer- } \\
\text { generated list." }\end{array}$ & (?) - no mention. & $\begin{array}{l}(+) \text { - blinding of the } \\
\text { operator not possible; } \\
\text { outcome assessment } \\
\text { safeguarded. }\end{array}$ & $\begin{array}{l}\text { (+) - "Two experienced } \\
\text { evaluators (A. S. and H. } \\
\text { T.), blinded with } \\
\text { respect to treatment } \\
\text { group, examined } \\
\text { independently the } \\
\text { biopsies..." }\end{array}$ & $\begin{array}{l}(+) \text { - only one patient excluded; } \\
\text { judged insignificant. }\end{array}$ & $\begin{array}{l}\text { (?) - It is difficult to judge } \\
\text { whether selective reporting is a } \\
\text { problem, as no protocol exists. }\end{array}$ & $\begin{array}{l}(-) \text { - smoking not } \\
\text { taken into account, } \\
\text { and membrane used } \\
\text { in some cases; no raw } \\
\text { data given. }\end{array}$ \\
\hline 21 & Kotsakis 2014 & $\begin{array}{l}\text { (?) - randomization not clear, } \\
\text { as experimental groups were } \\
\text { twice as large than the control } \\
\text { group and no description is } \\
\text { given: "were allocated to either } \\
\text { one of the test groups or the } \\
\text { control group according to a } \\
\text { randomization list." }\end{array}$ & (?) - no mention. & $\begin{array}{l}(+) \text { - blinding of the } \\
\text { operator not possible; } \\
\text { outcome assessment } \\
\text { safeguarded. }\end{array}$ & $\begin{array}{l}+(+) \text { "Clinical and } \\
\text { radiographic } \\
\text { postoperative } \\
\text { measurements were } \\
\text { recorded at } \\
\text { approximately } 5 \\
\text { months by the same } \\
\text { blinded examiner who } \\
\text { had performed the } \\
\text { baseline } \\
\text { measurements and } \\
\text { was not involved in } \\
\text { the surgical treatment" }\end{array}$ & $\begin{array}{l}(+) \text { - No drop-outs or patient } \\
\text { losses are reported. }\end{array}$ & $\begin{array}{l}\text { (?) - It is difficult to judge } \\
\text { whether selective reporting is a } \\
\text { problem, as no protocol exists. }\end{array}$ & $\begin{array}{l}(-) \text { - clustered } \\
\text { measurements } \\
\text { treated as } \\
\text { independent and no } \\
\text { raw data given. }\end{array}$ \\
\hline 22 & $\begin{array}{l}\text { Kuhl 2012; } \\
\text { Kuhl } 2013\end{array}$ & $\begin{array}{l}(+) \text { - "Before surgical } \\
\text { treatment, patients were } \\
\text { randomly enrolled in one of } \\
\text { three treatment groups:" } \\
\end{array}$ & (?) - no mention. & $\begin{array}{l}\text { (?) - blinding of the } \\
\text { operator not possible; } \\
\text { outcome assessment } \\
\text { unclear. }\end{array}$ & (?) - no mention. & $\begin{array}{l}(+) \text { - excluded patients evenly } \\
\text { distributed among groups. }\end{array}$ & $\begin{array}{l}\text { (?) - It is difficult to judge } \\
\text { whether selective reporting is a } \\
\text { problem, as no protocol exists. }\end{array}$ & $\begin{array}{l}(+) \text { - smoking and } \\
\text { systemic diseases } \\
\text { covered from the } \\
\text { exclusion criteria. }\end{array}$ \\
\hline 23 & Kurkcu 2012 & $\begin{array}{l}\text { (-) - semi-randomization: "The } \\
\text { patients were randomly } \\
\text { allocated to } 1 \text { of } 2 \text { groups } \\
\text { according to admission order." }\end{array}$ & (?) - no mention. & $\begin{array}{l}\text { (?) - blinding of the } \\
\text { operator not possible; } \\
\text { outcome assessment } \\
\text { unclear. }\end{array}$ & (?) - no mention. & $\begin{array}{l}(+) \text { - excluded patients evenly } \\
\text { distributed among groups. }\end{array}$ & $\begin{array}{l}\text { (?) - It is difficult to judge } \\
\text { whether selective reporting is a } \\
\text { problem, as no protocol exists. }\end{array}$ & $\begin{array}{l}(-) \text { - smoking not } \\
\text { taken into account, } \\
\text { and no raw data } \\
\text { given. }\end{array}$ \\
\hline 24 & Lee 2008 & $\begin{array}{l}\text { (?) - randomization unclear: } \\
\text { "Randomization schedules } \\
\text { were designed to provide a } \\
\text { balanced distribution of graft } \\
\text { material in each patient." } \\
\end{array}$ & (?) - no mention. & $\begin{array}{l}\text { (?) - blinding of the } \\
\text { operator not possible; } \\
\text { outcome assessment } \\
\text { unclear. }\end{array}$ & (?) - no mention. & $\begin{array}{l}(-) \text { - Selective random } \\
\text { reporting of samples, leading } \\
\text { to unequal distribution among } \\
\text { groups: "Ten randomly } \\
\text { selected bone core samples }\end{array}$ & $\begin{array}{l}\text { (?) - It is difficult to judge } \\
\text { whether selective reporting is a } \\
\text { problem, as no protocol exists. }\end{array}$ & $\begin{array}{l}(-) \text { - raw data are } \\
\text { given for each patient, } \\
\text { but smoking among } \\
\text { patients not reported. }\end{array}$ \\
\hline
\end{tabular}




\begin{tabular}{|c|c|c|c|c|c|c|c|c|}
\hline & & & & & & were examined" & & \\
\hline 25 & $\begin{array}{l}\text { Mardas 2010; } \\
\text { Mardas 2011; } \\
\text { Patel } 2013\end{array}$ & $\begin{array}{l}(+)-\text { "The subjects were } \\
\text { randomly assigned to the test } \\
\text { or the control group by a } \\
\text { computergenerated table. A } \\
\text { balanced randomly permuted } \\
\text { block approach was used to } \\
\text { prepare the randomization } \\
\text { tables in order to avoid } \\
\text { unequal balance between the } \\
\text { two treatments. The subjects } \\
\text { were randomized according to } \\
\text { smoking habits." }\end{array}$ & $\begin{array}{l}(+) \text { - "After } \\
\text { completion of the } \\
\text { intrasurgical } \\
\text { measurements, the } \\
\text { randomization } \\
\text { envelope was opened } \\
\text { and the assigned } \\
\text { treatment (test or } \\
\text { control) was } \\
\text { revealed to the } \\
\text { surgeon." }\end{array}$ & $\begin{array}{l}(+) \text { - blinding of the } \\
\text { operator not possible; } \\
\text { outcome assessment } \\
\text { safeguarded. }\end{array}$ & $\begin{array}{l}(+) \text { - "All the } \\
\text { periodontal and } \\
\text { intrasurgical } \\
\text { measurements were } \\
\text { made by a single, } \\
\text { blinded previously } \\
\text { calibrated examiner } \\
\text { other than the } \\
\text { surgeon, who was also } \\
\text { not aware of the } \\
\text { treatment assignment } \\
\text { (test or control)." }\end{array}$ & $\begin{array}{l}\text { (+) - One patient exclluded } \\
\text { after randomization and this } \\
\text { was judged to be insignificant: } \\
\text { "Two patients were excluded } \\
\text { before randomization due to } \\
\text { complete loss of the buccal } \\
\text { osseous plate following } \\
\text { extraction. One patient } \\
\text { withdrew from the study } \\
\text { before randomization and } \\
\text { another who had been } \\
\text { assigned to the test group quit } \\
\text { the study before implant } \\
\text { placement." }\end{array}$ & $\begin{array}{l}\text { (?) - It is difficult to judge } \\
\text { whether selective reporting is a } \\
\text { problem, as no protocol exists. }\end{array}$ & $\begin{array}{l}(+) \text { - smokers not } \\
\text { excluded, but } \\
\text { distributed equally } \\
\text { between groups. }\end{array}$ \\
\hline 26 & Meijndert 2005 & $\begin{array}{l}(+) \text { - "A computer software } \\
\text { program randomly placed the } \\
\text { participating patients into } \\
\text { these groups." }\end{array}$ & (?) - no mention. & $\begin{array}{l}\text { (?) - blinding of the } \\
\text { operator not possible; } \\
\text { outcome assessment } \\
\text { unclear. }\end{array}$ & (?) - no mention. & $\begin{array}{l}(+) \text { - No drop-outs or patient } \\
\text { losses are reported. }\end{array}$ & $\begin{array}{l}\text { (?) - It is difficult to judge } \\
\text { whether selective reporting is a } \\
\text { problem, as no protocol exists. }\end{array}$ & $\begin{array}{l}(+) \text { - smoking and } \\
\text { systemic diseases } \\
\text { covered from the } \\
\text { exclusion criteria. }\end{array}$ \\
\hline 27 & Meijndert 2008 & $\begin{array}{l}(+) \text { - "A computer software } \\
\text { program randomly placed the } \\
\text { participating patients into one } \\
\text { of these groups, using a } \\
\text { balancing procedure aimed at } \\
\text { an equal distribution of } \\
\text { patients over the treatment } \\
\text { groups regarding variables } \\
\text { that may interfere with the } \\
\text { outcome of the study" }\end{array}$ & (?) - no mention. & $\begin{array}{l}\text { (?) - blinding of the } \\
\text { operator not possible; } \\
\text { outcome assessment } \\
\text { unclear. }\end{array}$ & (?) - no mention. & $\begin{array}{l}(+)-2 \text { samples were } \\
\text { excluded/judged to be } \\
\text { insignificant. }\end{array}$ & $\begin{array}{l}\text { (?) - It is difficult to judge } \\
\text { whether selective reporting is a } \\
\text { problem, as no protocol exists. }\end{array}$ & $\begin{array}{l}(+) \text { - smoking and } \\
\text { systemic diseases } \\
\text { covered from the } \\
\text { exclusion criteria. }\end{array}$ \\
\hline 28 & Molly 2008 & $\begin{array}{l}\text { (-) - "the experimental } \\
\text { treatments, consisting of at } \\
\text { least two bone biomaterials } \\
\text { and one control, were applied } \\
\text { randomly in each subject": } \\
\text { randomization unclear, but the } \\
\text { paper is titled "Case series". }\end{array}$ & (?) - no mention. & $\begin{array}{l}\text { (?) - blinding of the } \\
\text { operator not possible; } \\
\text { outcome assessment } \\
\text { unclear. }\end{array}$ & (?) - no mention. & $\begin{array}{l}(+) \text { - No drop-outs or patient } \\
\text { losses are reported. }\end{array}$ & $\begin{array}{l}\text { (?) - It is difficult to judge } \\
\text { whether selective reporting is a } \\
\text { problem, as no protocol exists. }\end{array}$ & $\begin{array}{l}(-) \text { - clustered } \\
\text { measurements } \\
\text { treated correctly with } \\
\text { linear mixed } \\
\text { modelling, but not } \\
\text { clearly reported and } \\
\text { no raw data given. }\end{array}$ \\
\hline 29 & $\begin{array}{l}\text { Mordenfeld } \\
2014\end{array}$ & $\begin{array}{l}(+) \text { - probably adequate: "The } \\
\text { allocation sequence was } \\
\text { computer-generated by a } \\
\text { statistician at Gavleborg } \\
\text { County Hospital, Sweden, and } \\
\text { concealed in envelopes until } \\
\text { randomization." }\end{array}$ & $\begin{array}{l}(+) \text { - probably } \\
\text { adequate (same as } \\
\text { sequence } \\
\text { generation). }\end{array}$ & $\begin{array}{l}\text { (?) - blinding of the } \\
\text { operator not possible; } \\
\text { outcome assessment } \\
\text { unclear. }\end{array}$ & (?) - no mention. & $\begin{array}{l}\text { (+) - "All } 28 \text { specimens, } 14 \\
\text { from each mixture and grafted } \\
\text { site, could be used for } \\
\text { histomorphometry, and the } \\
\text { grafted tissue was easily } \\
\text { distinguished from the } \\
\text { residual bone." }\end{array}$ & $\begin{array}{l}\text { (?) - It is difficult to judge } \\
\text { whether selective reporting is a } \\
\text { problem, as the trial was not } \\
\text { registered and no protocol } \\
\text { exists. }\end{array}$ & $\begin{array}{l}\text { (+) - clustered } \\
\text { measurements } \\
\text { treated correctly with } \\
\text { regression modelling } \\
\text { (smoking and } \\
\text { systemic diseases } \\
\text { covered from the } \\
\text { exclusion criteria). } \\
\end{array}$ \\
\hline 30 & Piattelli 2002 & $\begin{array}{l}\text { (?) - "The defects were filled in } \\
\text { a random manner with } \\
\text { autologous bone harvested } \\
\text { with a trephine from adjacent } \\
\text { areas and ground in a bone }\end{array}$ & (?) - no mention. & $\begin{array}{l}\text { (?) - blinding of the } \\
\text { operator not possible; } \\
\text { outcome assessment } \\
\text { unclear. }\end{array}$ & (?) - no mention. & $\begin{array}{l}(+) \text { - No drop-outs or patient } \\
\text { losses are reported. }\end{array}$ & $\begin{array}{l}\text { (?) - It is difficult to judge } \\
\text { whether selective reporting is a } \\
\text { problem, as no protocol exists. }\end{array}$ & $\begin{array}{l}\text { (?) - no mention of } \\
\text { smoking as an } \\
\text { inclusion/exclusion } \\
\text { criterion. }\end{array}$ \\
\hline
\end{tabular}




\begin{tabular}{|c|c|c|c|c|c|c|c|c|}
\hline & & mill, or with Bio-Oss." & & & & & & \\
\hline 31 & Pikdoken 2011 & $\begin{array}{l}\text { (?) - randomization unclear: "A } \\
\text { balanced randomization was } \\
\text { performed by a clinician who } \\
\text { intended to distribute the } \\
\text { patients into } 2 \text { groups } \\
\text { including equal numbers of } \\
\text { patients." }\end{array}$ & (?) - no mention. & $\begin{array}{l}(+) \text { - blinding of the } \\
\text { operator not possible; } \\
\text { outcome assessment } \\
\text { safeguarded. }\end{array}$ & $\begin{array}{l}+(+) \text { - "Histologic and } \\
\text { histomorphometric } \\
\text { assessments were } \\
\text { carried out by } 2 \\
\text { pathologists (Z.K. and } \\
\text { E.B.) who were not } \\
\text { informed about the } \\
\text { treatment modalities." }\end{array}$ & $\begin{array}{l}(+) \text { - No drop-outs or patient } \\
\text { losses are reported. }\end{array}$ & $\begin{array}{l}\text { (?) - It is difficult to judge } \\
\text { whether selective reporting is a } \\
\text { problem, as no protocol exists. }\end{array}$ & $\begin{array}{l}(+) \text { - smoking and } \\
\text { systemic diseases } \\
\text { covered from the } \\
\text { exclusion criteria. }\end{array}$ \\
\hline 32 & $\begin{array}{l}\text { Raghoebar } \\
2005\end{array}$ & $\begin{array}{l}\text { (?) - randomization unclear: } \\
\text { "Randomly, one side was } \\
\text { reconstructed with autologous } \\
\text { bone mixed with PRP gel and } \\
\text { one side with autologous bone } \\
\text { only." }\end{array}$ & (?) - no mention. & $\begin{array}{l}(+) \text { - blinding of the } \\
\text { operator not possible; } \\
\text { outcome assessment } \\
\text { safeguarded. }\end{array}$ & $\begin{array}{l}\text { (+) - "The } \\
\text { investigators were } \\
\text { blinded for both the } \\
\text { clinical and laboratory } \\
\text { investigations with } \\
\text { regard to the PRP- } \\
\text { treated side." }\end{array}$ & $\begin{array}{l}(+) \text { - No drop-outs or patient } \\
\text { losses are reported. }\end{array}$ & $\begin{array}{l}\text { (?) - It is difficult to judge } \\
\text { whether selective reporting is a } \\
\text { problem, as no protocol exists. }\end{array}$ & $\begin{array}{l}(-) \text { - raw data are } \\
\text { given for each patient, } \\
\text { but no mention of } \\
\text { smoking as an } \\
\text { inclusion/exclusion } \\
\text { criterion. }\end{array}$ \\
\hline 33 & Rickert 2011 & $\begin{array}{l}(+) \text { - randomization somewhat } \\
\text { unclear, but judged to be } \\
\text { adequate: "Randomly, } \\
\text { performed by envelopes, on } \\
\text { one side the augmentation } \\
\text { procedure was performed with } \\
\text { bovine bone mineral (BioOsss, } \\
\text { Geistlich Biomaterials, } \\
\text { Wolhusen, Switzerland) } \\
\text { seeded with MSCs harvested" }\end{array}$ & $\begin{array}{l}(+) \text { - no mention if } \\
\text { the envelopes were } \\
\text { opaque and } \\
\text { sequentially- } \\
\text { numbered, but } \\
\text { judged to be } \\
\text { adequate (same as } \\
\text { sequence } \\
\text { generation). }\end{array}$ & $\begin{array}{l}(+) \text { - blinding of the } \\
\text { operator not possible; } \\
\text { outcome assessment } \\
\text { safeguarded. }\end{array}$ & $\begin{array}{l}(+) \text { - "The histologists } \\
\text { were blinded to the } \\
\text { samples' groups } \\
\text { throughout the } \\
\text { histomorphometrical } \\
\text { analysis." }\end{array}$ & $\begin{array}{l}(+)-\text { One patient excluded, but } \\
\text { reasoning adequate. }\end{array}$ & $\begin{array}{l}\text { (?) - It is difficult to judge } \\
\text { whether selective reporting is a } \\
\text { problem, as no protocol exists. }\end{array}$ & $\begin{array}{l}(+) \text { - raw data are } \\
\text { given for each patient } \\
\text { (smoking and } \\
\text { systemic diseases } \\
\text { covered from the } \\
\text { exclusion criteria). }\end{array}$ \\
\hline 34 & Schmitt 2013 & $\begin{array}{l}\text { (?) - randomization unclear: } \\
\text { "The test groups (ABB, BCP, } \\
\text { and MCBA) and the control } \\
\text { group (AB) were allocated to } \\
\text { the participant's sinus under } \\
\text { randomized conditions." }\end{array}$ & (?) - no mention. & $\begin{array}{l}\text { (?) - blinding of the } \\
\text { operator not possible; } \\
\text { outcome assessment } \\
\text { unclear. }\end{array}$ & (?) - no mention. & $\begin{array}{l}(+) \text { - only half of the harvested } \\
\text { samples were analyzed. } \\
\text { However, as the distribution } \\
\text { among the interventions was } \\
\text { relatively well-balanced, it was } \\
\text { assumed to have no effect on } \\
\text { the results (although the } \\
\text { authors didn't formally assess } \\
\text { this): "Fifty-three bone } \\
\text { biopsies were generated from } \\
\text { the later implant site; } 41 \\
\text { samples were lost during } \\
\text { removal or the location of the } \\
\text { implant was peripheral to the } \\
\text { augmented maxillary sinus." }\end{array}$ & $\begin{array}{l}\text { (?) - It is difficult to judge } \\
\text { whether selective reporting is a } \\
\text { problem, as no protocol exists. }\end{array}$ & $\begin{array}{l}(-) \text { - clustered } \\
\text { measurements } \\
\text { treated as } \\
\text { independent, } \\
\text { smoking not taken } \\
\text { into account, and no } \\
\text { raw data given. }\end{array}$ \\
\hline 35 & $\begin{array}{l}\text { Shirmohamma } \\
\text { di } 2014\end{array}$ & $\begin{array}{l}\text { (?) - "After elevation of the } \\
\text { sinusmembrane on a random } \\
\text { basis, on one } \\
\text { side,Ostim(Heraeus Kulzer } \\
\text { GmbH and } 63450 \text { Hanau, } \\
\text { Germany) with } 20 \% \\
\text { autogenous bone graft was } \\
\text { used and on the other side Bio- } \\
\text { Oss (Geistlich Pharma AG and } \\
6110 \text { Wolhusen, Switzerland) }\end{array}$ & (?) - no mention. & $\begin{array}{l}(+) \text { - blinding of the } \\
\text { operator not possible; } \\
\text { outcome assessment } \\
\text { safeguarded. }\end{array}$ & $\begin{array}{l}(+) \text { - "The histologist } \\
\text { (LR) was blinded to } \\
\text { the type of the bone } \\
\text { grafts used in sinus } \\
\text { augmentation." }\end{array}$ & $\begin{array}{l}(+) \text { - One drop-outs or patient } \\
\text { losses reported. Due to the } \\
\text { split-mouth nature, } \\
\text { observations are balanced. }\end{array}$ & $\begin{array}{l}(+) \text { - No serious discrepancies } \\
\text { between published report and } \\
\text { registration } \\
\text { (http://www.irct.ir/searchresu } \\
\text { lt.php?keyword=IRCT2012041 } \\
\text { 57128N2\&id=7128\&number=2 } \\
\text { \&field=a\&prt=1\&total=1\&m=1) }\end{array}$ & $\begin{array}{l}(+) \text { - raw data are } \\
\text { given for each patient } \\
\text { (smoking and } \\
\text { systemic diseases } \\
\text { covered from the } \\
\text { exclusion criteria). }\end{array}$ \\
\hline
\end{tabular}




\begin{tabular}{|c|c|c|c|c|c|c|c|c|}
\hline & & $\begin{array}{l}\text { with } 20 \% \text { autogenous bone } \\
\text { graft was applied." }\end{array}$ & & & & & & \\
\hline 36 & Szabo 2005 & $\begin{array}{l}(+) \text { - "The choice of sides was } \\
\text { randomized using the coin-toss } \\
\text { method." }\end{array}$ & (?) - no mention. & $\begin{array}{l}\text { (?) - blinding of the } \\
\text { operator not possible; } \\
\text { outcome assessment } \\
\text { unclear. }\end{array}$ & (?) - no mention. & $\begin{array}{l}(+) \text { - No drop-outs or patient } \\
\text { losses are reported. }\end{array}$ & $\begin{array}{l}\text { (?) - It is difficult to judge } \\
\text { whether selective reporting is a } \\
\text { problem, as no protocol exists. }\end{array}$ & $\begin{array}{l}(-) \text { - raw data are } \\
\text { given for each patient } \\
\text { (systemic diseases } \\
\text { covered from the } \\
\text { exclusion criteria). } \\
\text { However, no mention } \\
\text { of smoking as an } \\
\text { inclusion/exclusion } \\
\text { criterion. }\end{array}$ \\
\hline 37 & Tosta 2013 & $\begin{array}{l}\text { (?) - "The space created was } \\
\text { grafted - to allow the future } \\
\text { placement of implants of 12- } \\
\text { mm in length - with either a } \\
\text { synthetic particulate bone } \\
\text { substitute (test group - } \\
\text { biphasic calciumphosphate - } \\
\text { Straumann BoneCeramic@, } \\
\text { Institut Straumann AG), or } \\
\text { with a particulate autogenous } \\
\text { bone graft harvested } \\
\text { intraorally from the tuberosity } \\
\text { area (control group), } \\
\text { depending on the } \\
\text { randomization process." }\end{array}$ & (?) - no mention. & $\begin{array}{l}\text { (?) - blinding of the } \\
\text { operator not possible; } \\
\text { outcome assessment } \\
\text { unclear. }\end{array}$ & (?) - no mention. & $\begin{array}{l}(+) \text { - No drop-outs or patient } \\
\text { losses are reported. }\end{array}$ & $\begin{array}{l}\text { (?) - It is difficult to judge } \\
\text { whether selective reporting is a } \\
\text { problem, as no protocol exists. }\end{array}$ & $\begin{array}{l}(+) \text { - smoking and } \\
\text { systemic diseases } \\
\text { covered from the } \\
\text { exclusion criteria. }\end{array}$ \\
\hline 38 & Wagner 2012 & $\begin{array}{l}\text { (+) - somewhat unclear, but } \\
\text { judged to be adequate: } \\
\text { "Immediately prior to study } \\
\text { treatment, the investigator } \\
\text { opened a sealed randomization } \\
\text { envelope containing the } \\
\text { assignment of the MBCP-FS } \\
\text { graft treatment to either the } \\
\text { right or the left sinus." }\end{array}$ & $\begin{array}{l}(+) \text { - somewhat } \\
\text { unclear, but judged } \\
\text { to be adequate (same } \\
\text { as sequence } \\
\text { generation). }\end{array}$ & $\begin{array}{l}\text { (?) - blinding of the } \\
\text { operator not possible; } \\
\text { outcome assessment } \\
\text { unclear. }\end{array}$ & (?) - no mention. & $\begin{array}{l}(+) \text { - No drop-outs or patient } \\
\text { losses are reported. }\end{array}$ & $\begin{array}{l}\text { (?) - It is difficult to judge } \\
\text { whether selective reporting is a } \\
\text { problem, as no protocol exists. }\end{array}$ & $\begin{array}{l}\text { (?) - no mention of } \\
\text { smoking as an } \\
\text { inclusion/exclusion } \\
\text { criterion. }\end{array}$ \\
\hline 39 & Wiltfang 2003 & $\begin{array}{l}\text { (?) - "One milliliter of PRP was } \\
\text { administered in addition to the } \\
\text { ceramic material in } 17 \text { sites in } \\
\text { a randomized prospective } \\
\text { study approved by the ethics } \\
\text { commission of the University } \\
\text { of Erlangen-Nuremberg } \\
\text { (application no. 2075)." }\end{array}$ & (?) - no mention. & $\begin{array}{l}\text { (?) - blinding of the } \\
\text { operator not possible; } \\
\text { outcome assessment } \\
\text { unclear. }\end{array}$ & (?) - no mention. & $\begin{array}{l}(+) \text { - No drop-outs or patient } \\
\text { losses are reported. }\end{array}$ & $\begin{array}{l}(-) \text { - It is difficult to judge } \\
\text { whether selective reporting is a } \\
\text { problem, as no protocol exists. } \\
\text { Data not adequately reported } \\
\text { to allow processing. }\end{array}$ & $\begin{array}{l}\text { (?) - no mention of } \\
\text { smoking as an } \\
\text { inclusion/exclusion } \\
\text { criterion. }\end{array}$ \\
\hline 40 & Wood 2012 & $\begin{array}{l}(+) \text { - randomization somewhat } \\
\text { unclear, but judged to be } \\
\text { adequate: "Forty patients were } \\
\text { enrolled, and each participant } \\
\text { was assigned to one of the two }\end{array}$ & $\begin{array}{l}+(+) \text { - allocation } \\
\text { concealment } \\
\text { somewhat unclear, } \\
\text { but judged to be } \\
\text { adequate (same as }\end{array}$ & $\begin{array}{l}\text { (?) - blinding of the } \\
\text { operator not possible; } \\
\text { outcome assessment } \\
\text { unclear. }\end{array}$ & (?) - no mention. & $\begin{array}{l}(-) \text { - Thirtytwo out of forty } \\
\text { samples analyzed and } \\
\text { distribution between } \\
\text { experimenal groups not } \\
\text { assessed. }\end{array}$ & $\begin{array}{l}\text { (?) - It is difficult to judge } \\
\text { whether selective reporting is a } \\
\text { problem, as no protocol exists. }\end{array}$ & $\begin{array}{l}(+) \text { - smokers not } \\
\text { actively excluded, but } \\
\text { no smokers were } \\
\text { enrolled. }\end{array}$ \\
\hline
\end{tabular}




\begin{tabular}{|c|c|c|c|c|c|c|c|c|}
\hline & & $\begin{array}{l}\text { treatment groups at the time of } \\
\text { surgery by random selection of } \\
\text { sealed envelopes." }\end{array}$ & $\begin{array}{l}\text { sequence } \\
\text { generation). }\end{array}$ & & & & & \\
\hline 41 & Xavier 2014 & $\begin{array}{l}\text { (+) - randomization somewhat } \\
\text { unclear, but judged to be } \\
\text { adequate: "The choice of } \\
\text { whether the sinus (left or } \\
\text { right) would contain the test } \\
\text { substance (fresh frozen bone) } \\
\text { or autologous bone was } \\
\text { determined randomly, using a } \\
\text { randomized table." }\end{array}$ & (?) - no mention. & $\begin{array}{l}\text { (?) - blinding of the } \\
\text { operator not possible; } \\
\text { outcome assessment } \\
\text { unclear. }\end{array}$ & (?) - no mention. & $\begin{array}{l}(+) \text { - No drop-outs or patient } \\
\text { losses are reported. }\end{array}$ & $\begin{array}{l}\text { (?) - It is difficult to judge } \\
\text { whether selective reporting is a } \\
\text { problem, as no protocol exists. }\end{array}$ & $\begin{array}{l}(+) \text { - smoking and } \\
\text { systemic diseases } \\
\text { covered from the } \\
\text { exclusion criteria. }\end{array}$ \\
\hline
\end{tabular}

$(+)$, low risk of bias; (-), high risk of bias; (?), unclear risk of bias. 
Appendix 8. Risk of bias of the 41 trials included in the systematic review. A, selection bias - random sequence; $B$, selection bias - allocation; $C$, performance bias; $D$, detection bias; $E$, attrition bias; $F$, reporting bias; $G$, other bias.

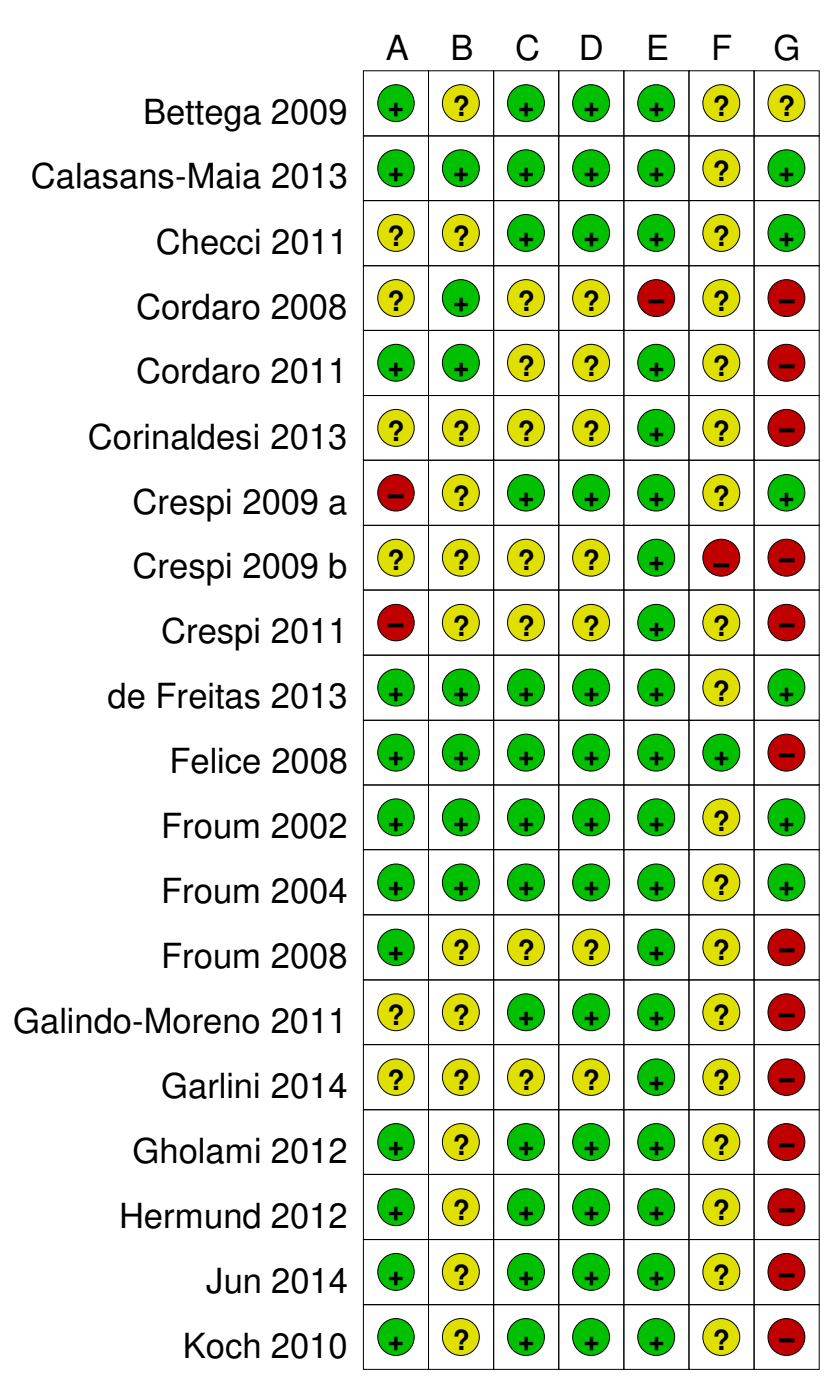

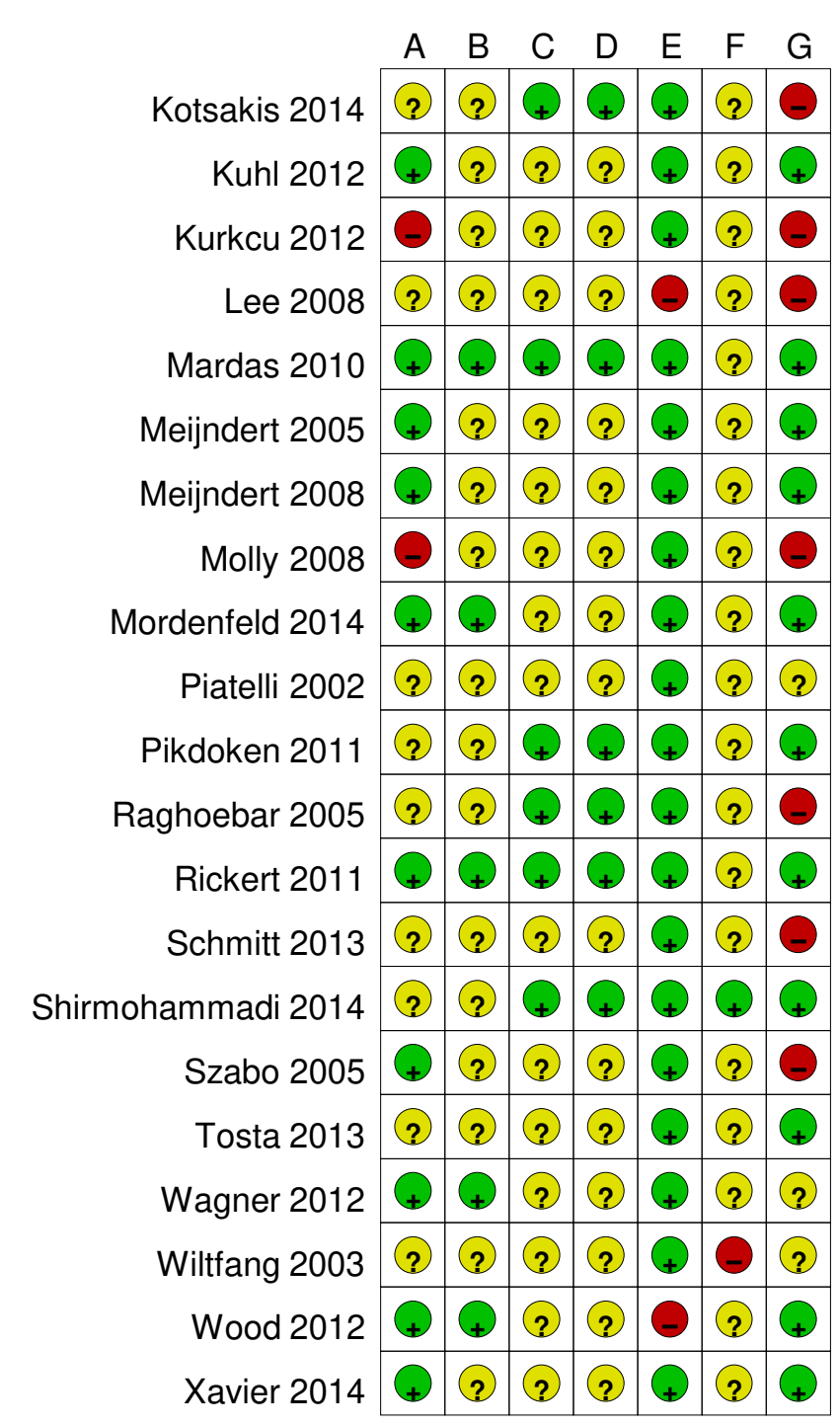


Appenfix 9. Risk of bias summary across the 41 trials included in the systematic review. $A$, selection bias - random sequence; $B$, selection bias allocation; C, performance bias; D, detection bias; E, attrition bias; F, reporting bias; G, other bias.

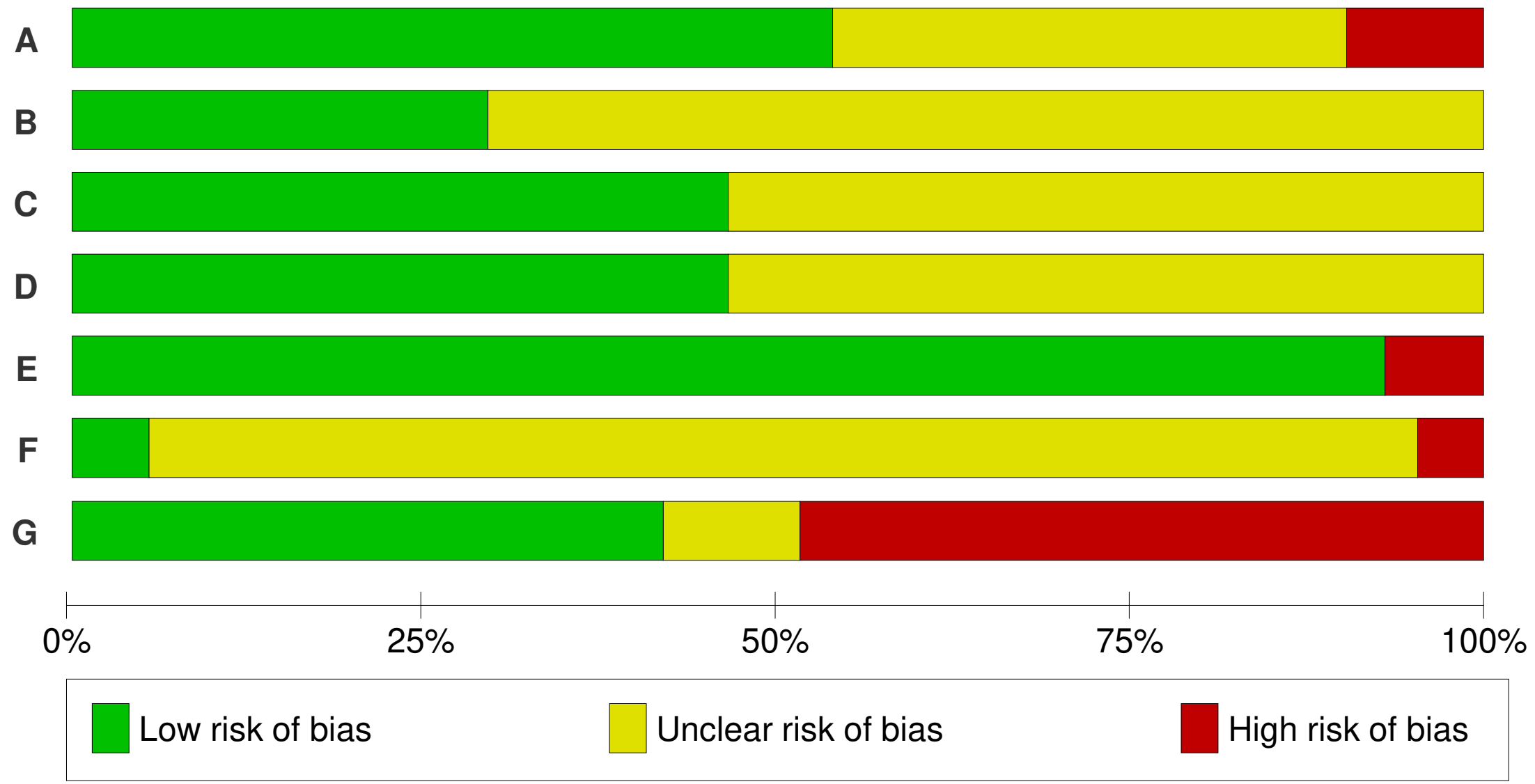


Appendix 10. Results of individual trials included in the systematic review, including all reported outcomes. Adjusted estimates stem from individual participant data and are controlled for patient, age, sex, and membrane (where applicable).

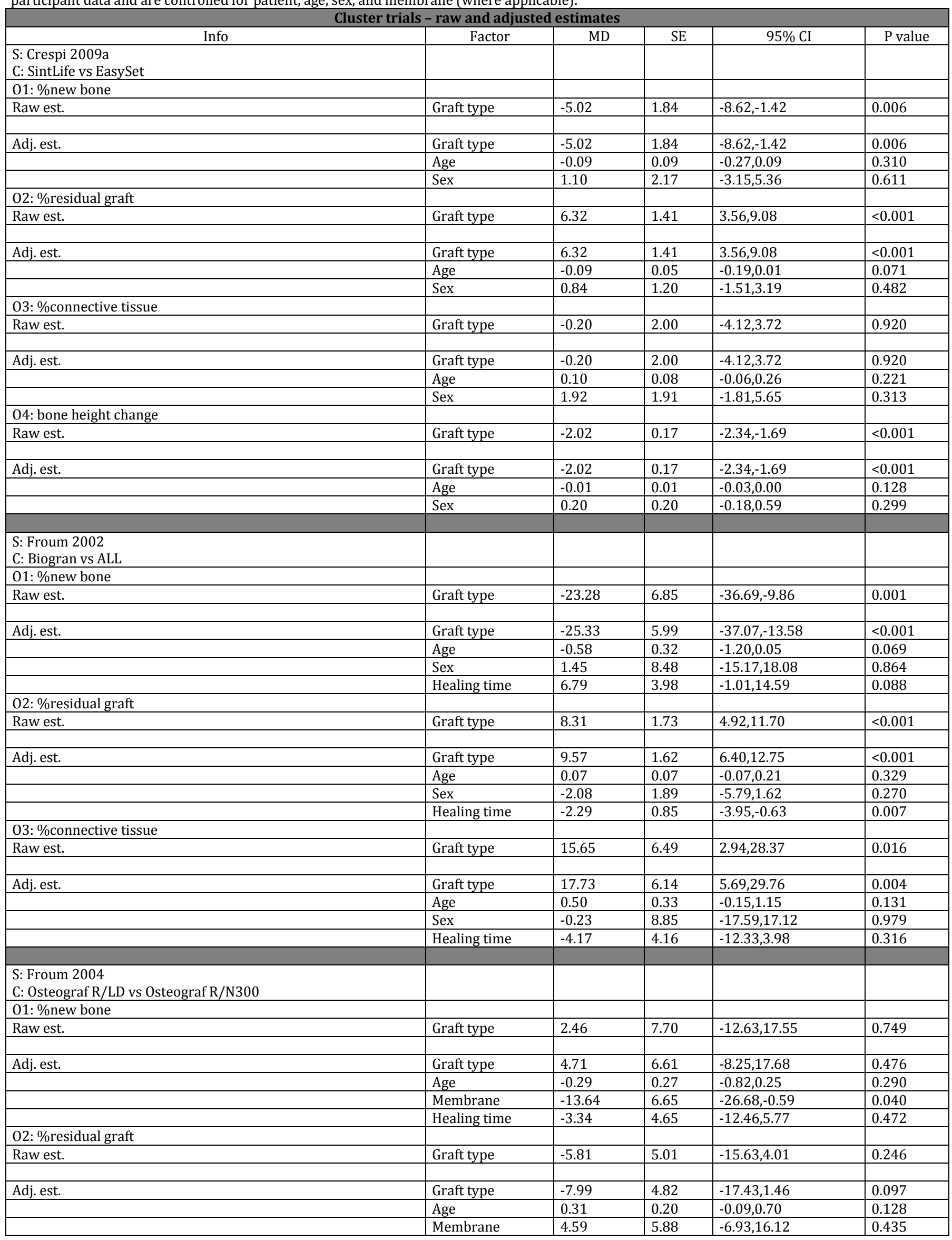




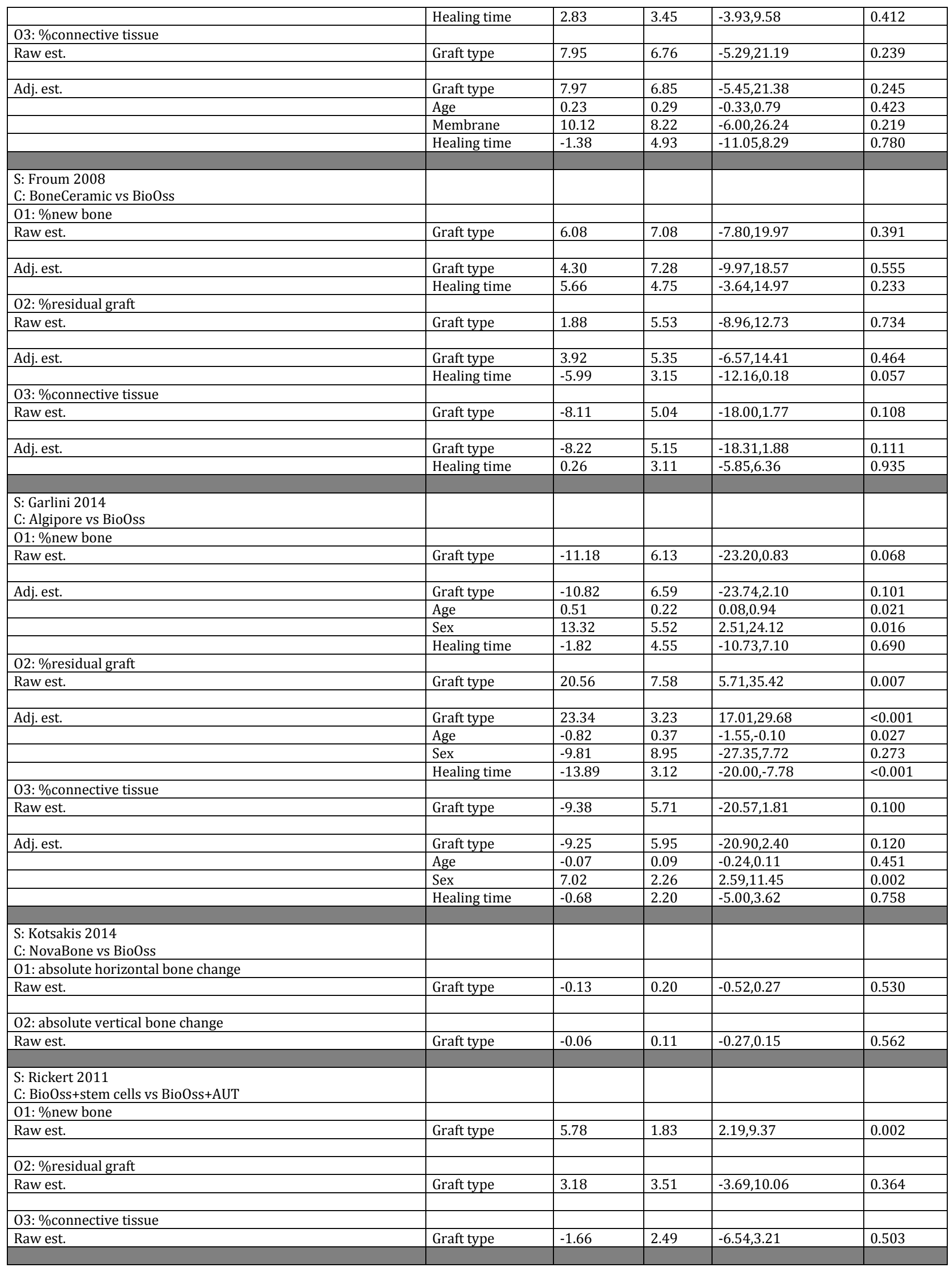




\begin{tabular}{|c|c|c|c|c|c|}
\hline \multicolumn{6}{|l|}{$\begin{array}{l}\text { S: Shirmohammadi } 2014 \\
\text { C: Ostim vs BioOss }\end{array}$} \\
\hline \multicolumn{6}{|l|}{ 01: \%new bone } \\
\hline Raw est. & Graft type & 6.19 & 1.48 & $3.29,9.09$ & $<0.001$ \\
\hline \multicolumn{6}{|l|}{ 02: \%residual graft } \\
\hline Raw est. & Graft type & -9.96 & 2.32 & $-14.51,-5.41$ & $<0.001$ \\
\hline \multicolumn{6}{|l|}{ 03: \%connective tissue } \\
\hline Raw est. & Graft type & 3.78 & 3.25 & $-2.59,10.14$ & 0.245 \\
\hline \multicolumn{6}{|l|}{ 04: bone density } \\
\hline Raw est. & Graft type & 22.00 & 8.00 & $6.32,37.68$ & 0.006 \\
\hline \multicolumn{6}{|l|}{ 05: bone height } \\
\hline Raw est. & Graft type & 0.52 & 0.35 & $-0.17,1.21$ & 0.138 \\
\hline \multicolumn{6}{|l|}{$\begin{array}{l}\text { S: Szab02005 } \\
\text { C: Cerasorb vs AUT }\end{array}$} \\
\hline \multicolumn{6}{|l|}{ 01: \%new bone } \\
\hline Raw est. & Graft type & -1.88 & 1.94 & $-5.69,1.93$ & 0.333 \\
\hline \multicolumn{6}{|l|}{ 02: \%residual graft } \\
\hline Raw est. & Graft type & 5.50 & 1.01 & $3.52,7.48$ & $<0.001$ \\
\hline \multicolumn{6}{|l|}{ 03: \%connective tissue } \\
\hline Raw est. & Graft type & -3.61 & 1.91 & $-7.36,0.13$ & 0.059 \\
\hline \multicolumn{6}{|l|}{$\begin{array}{l}\text { S: Xavier } 2014 \\
\text { C: AUT vs ALL }\end{array}$} \\
\hline \multicolumn{6}{|l|}{ 01: \%new bone } \\
\hline Raw est. & Graft type & -0.01 & 0.48 & $-0.95,0.93$ & 0.981 \\
\hline \multicolumn{6}{|l|}{ 02: \%residual graft } \\
\hline Raw est. & Graft type & -1.16 & 2.57 & $-6.20,3.89$ & 0.653 \\
\hline \multicolumn{6}{|l|}{ 03: \%connective tissue } \\
\hline Raw est. & Graft type & 1.17 & 2.59 & $-3.92,6.25$ & 0.653 \\
\hline \multicolumn{6}{|c|}{ Parallel trials - Raw estimates - MD (unless stated otherwise) } \\
\hline \multicolumn{6}{|l|}{$\begin{array}{l}\text { S: Calasans-Maia } 2013 \\
\text { C: Osseus vs BioOss }\end{array}$} \\
\hline & Graft type & & & & \\
\hline 01: \%new bone & & 14.4 & 7.49 & $-0.28,29.08$ & 0.055 \\
\hline 02: \%residual graft & & -11.9 & 5.70 & $-23.07,-0.73$ & 0.037 \\
\hline 03: \%connective tissue & & -17.6 & 5.27 & $-27.93,-7.27$ & 0.001 \\
\hline 04: bone width change & & -0.10 & 0.06 & $-0.23,0.03$ & 0.130 \\
\hline \multicolumn{6}{|l|}{$\begin{array}{l}\text { S: Checci } 2011 \\
\text { C: SintLife vs Ostim }\end{array}$} \\
\hline & Graft type & & & & \\
\hline 01: \%new bone & & 5.00 & 15.92 & $-26.21,36.21$ & 0.754 \\
\hline 02: \%residual graft & & -6.00 & 4.43 & $-14.68,2.68$ & 0.175 \\
\hline 03: \%connective tissue & & -4.00 & 4.60 & $-13.02,5.02$ & 0.385 \\
\hline \multicolumn{6}{|l|}{$\begin{array}{l}\text { S: CordarO2011 } \\
\text { C: AUT vs BioOss+AUT }\end{array}$} \\
\hline & Graft type & & & & \\
\hline 01: final bone gain & & 0.26 & 0.53 & $-0.77,1.29$ & 0.622 \\
\hline 02: final bone resorption & & -0.64 & 0.55 & $-1.72,0.44$ & 0.243 \\
\hline \multicolumn{6}{|l|}{$\begin{array}{l}\text { S: de Freitas } 2013 \\
\text { C: rhBMP-2/ACS vs AUT }\end{array}$} \\
\hline & Graft type & & & & \\
\hline 01: clin. bone width & & -0.50 & 0.48 & $-1.44,0.44$ & 0.298 \\
\hline 02: rad. bone width $2 \mathrm{~mm}$ from crest & & 1.00 & 0.33 & $0.36,1.65$ & 0.002 \\
\hline 03: rad. bone width $6 \mathrm{~mm}$ from crest & & 0.00 & 0.35 & $-0.68,0.68$ & 1.00 \\
\hline 04: rad. bone width $10 \mathrm{~mm}$ from crest & & -0.100 & 0.41 & $-0.90,0.70$ & 0.807 \\
\hline 05: implant failure (primary stability) & & RR:6.56 & 1.04 & $0.89,50.23$ & 0.070 \\
\hline S: Galindo-Moren02011 & & & & & \\
\hline
\end{tabular}




\begin{tabular}{|c|c|c|c|c|c|}
\hline \multicolumn{6}{|l|}{ C: BioOss+AUT(8/2) vs BioOss+AUT (5/5) } \\
\hline & Graft type & & & & \\
\hline 01: \%vital bone & & 1.38 & 5.30 & $-9.02,11.78$ & 0.795 \\
\hline 02: \%residual graft & & 11.39 & 6.30 & $-0.95,23.73$ & 0.070 \\
\hline 03: \%non-mineralized tissue & & -12.88 & 5.61 & $-23.87,-1.89$ & 0.022 \\
\hline 04: osteoblast cells & & -84.84 & 61.10 & $-204.59,34.91$ & 0.165 \\
\hline 05: osteoclast cells & & -55.97 & 47.14 & $-148.37,36.43$ & 0.235 \\
\hline 06: osteocytes & & -412.77 & 164.82 & $-735.80,-89.74$ & 0.012 \\
\hline 07: osteoid lines & & -9.04 & 3.36 & $-15.62,-2.46$ & 0.007 \\
\hline \multicolumn{6}{|c|}{$\begin{array}{l}\text { S: Hermund } 2012 \\
\text { C: BioOss+autograft+bone cells vs BioOss+autograft }\end{array}$} \\
\hline & Graft type & & & & \\
\hline 01: bone density at position 1 & & 5.00 & 8.17 & $-11.01,21.01$ & 0.540 \\
\hline 02: bone density at position 2 & & 5.00 & 7.43 & $-9.56,19.56$ & 0.501 \\
\hline 03: bone density at position 3 & & -11.00 & 8.42 & $-27.51,5.51$ & 0.192 \\
\hline \multicolumn{6}{|l|}{$\begin{array}{l}\text { S: Jun } 2014 \\
\text { C: BioOss vs AUT }\end{array}$} \\
\hline & Graft type & & & & \\
\hline 01: \%new bone & & -4.58 & 4.17 & $-12.76,3.60$ & 0.272 \\
\hline 02: \%residual graft & & 2.12 & 4.91 & $-7.51,11.75$ & 0.666 \\
\hline 03: \%connective tissue & & 2.45 & 6.69 & $-10.66,15.56$ & 0.714 \\
\hline 04: osteoid thickness & & -4.77 & 1.72 & $-8.14,-1.40$ & 0.006 \\
\hline 05: new bone radioopacity (HU) & & -51.23 & 38.36 & $-126.42,23.96$ & 0.182 \\
\hline 06: new bone mineral density & & -0.02 & 0.01 & $-0.03,-0.01$ & 0.005 \\
\hline 07: trabecular thickness & & -0.01 & 0.01 & $-0.02,0.00$ & 0.087 \\
\hline 08: (micro-CT) \%new bone/total bone & & -4.76 & 3.90 & $-12.41,2.89$ & 0.222 \\
\hline \multicolumn{6}{|c|}{$\begin{array}{l}\text { Koch } 2010+\text { following } \\
\text { C: rhGDF-5+Ceraver Osteal vs AUT+Ceraver Osteal }\end{array}$} \\
\hline & Graft type & & & & \\
\hline 01: \%new bone & & -3.80 & 7.49 & $-18.48,10.88$ & 0.612 \\
\hline 02: \%bone marrow & & 12.10 & 7.58 & $-2.76,26.96$ & 0.111 \\
\hline 03: \%dense fibrous tissue & & 1.60 & 11.47 & $-20.89,24.09$ & 0.889 \\
\hline 04: \%residual graft & & -9.90 & 4.37 & $-18.47,-1.34$ & 0.023 \\
\hline \multicolumn{6}{|l|}{$\begin{array}{l}\text { Kuhl 2012; Kuhl } 2013 \\
\text { C: AUT vs Cerasorb or BoneCeramic }\end{array}$} \\
\hline \multirow[t]{2}{*}{ 01: bone density } & Cerasorb & -23.00 & 37.01 & $-95.55,49.55$ & 0.534 \\
\hline & BoneCeramic & -20.00 & 32.29 & $-83.29,43.29$ & 0.536 \\
\hline \multirow[t]{2}{*}{ 02: bone volume } & Cerasorb & -4.10 & 3.80 & $-11.54,3.34$ & 0.280 \\
\hline & BoneCeramic & -0.70 & 4.29 & $-9.11,7.71$ & 0.870 \\
\hline \multicolumn{6}{|l|}{ C: Cerasorb vs BoneCeramic } \\
\hline 03: \%residual graft & & 0.10 & 2.44 & $-4.69,4.89$ & 0.967 \\
\hline \multicolumn{6}{|l|}{$\begin{array}{l}\text { S: Kurkcu } 2012 \\
\text { C: BoneCeramic vs BonePlus-xs }\end{array}$} \\
\hline & Graft type & & & & \\
\hline 01: \%new bone & & 9.04 & 1.32 & $6.46,11.62$ & $<0.001$ \\
\hline 02: \%residual graft & & -2.17 & 1.93 & $-5.95,1.61$ & 0.261 \\
\hline 03: \%connective tissue & & -6.87 & 2.13 & $-11.04,-2.70$ & 0.001 \\
\hline \multicolumn{6}{|l|}{$\begin{array}{l}\text { Mardas } 2010+\text { following } \\
\text { C: BoneCeramic vs BioOss }\end{array}$} \\
\hline & Graft type & & & & \\
\hline 01: change in probing depth & & 0.30 & 0.16 & $-0.01,0.61$ & 0.056 \\
\hline 02: change in gingival recession & & -0.10 & 0.06 & $-0.22,0.02$ & 0.107 \\
\hline 03: change in bone width & & 1.00 & 0.39 & $0.23,1.77$ & 0.011 \\
\hline 04: change in Bbw & & -0.30 & 0.28 & $-0.84,0.24$ & 0.279 \\
\hline 05: change in $\mathrm{L} / \mathrm{Pbw}$ & & -0.40 & 0.32 & $-1.02,0.22$ & 0.206 \\
\hline 06: change in $\mathrm{Mbh}$ & & -0.60 & 0.34 & $-1.27,0.07$ & 0.080 \\
\hline 07: change in Dbh & & 0.00 & 0.40 & $-0.79,0.79$ & 1.00 \\
\hline 08: hard bone tissue after healing & & RR:1.00 & 0.92 & $0.17,6.07$ & 1.00 \\
\hline 09: implant failure & & RR:0.92 & 0.92 & $0.15,5.56$ & 0.930 \\
\hline 010: fenestrations around implants & & RR:3.00 & 1.09 & $0.36,25.21$ & 0.312 \\
\hline 011: pristine defects around implants & & RR:1.00 & 0.59 & $0.32,3.17$ & 1.000 \\
\hline
\end{tabular}




\begin{tabular}{|c|c|c|c|c|c|}
\hline 012: dehiscence around imlpants & & RR:0.86 & 0.86 & $0.40,1.86$ & 0.696 \\
\hline \multicolumn{6}{|c|}{ Various more specific bone height measurements omitted } \\
\hline \multicolumn{6}{|l|}{$\begin{array}{l}\text { S: Meijnert } 2005 \\
\text { C: BioOss vs AUT }\end{array}$} \\
\hline & Graft type & & & & \\
\hline 01: \%new bone & & -40.10 & 8.28 & $-56.32,-23.88$ & $<0.001$ \\
\hline 02: \%connective tissue & & -0.40 & 7.80 & $-15.68,14.88$ & 0.959 \\
\hline \multicolumn{6}{|l|}{$\begin{array}{l}\text { S: Meijnert } 2008 \\
\text { C: BioOss vs AUT }\end{array}$} \\
\hline & Graft type & & & & \\
\hline 01: bone mesial to implant & & -0.03 & 0.19 & $-0.40,0.34$ & 0.872 \\
\hline 02: bone distal to implant & & -0.03 & 0.14 & $-0.30,0.24$ & 0.826 \\
\hline 03: gingiva mesial to implant & & 0.11 & 0.12 & $-0.13,0.35$ & 0.368 \\
\hline 04: gingiva distal to implant & & 0.16 & 0.16 & $-0.15,0.47$ & 0.264 \\
\hline 05: gingiva buccal to implant & & -0.21 & 0.19 & $-0.58,0.16$ & 0.720 \\
\hline \multicolumn{6}{|c|}{$\begin{array}{l}\text { Various measurement at the teeth adjacent to the grafted area } \\
\text { omitted }\end{array}$} \\
\hline \multicolumn{6}{|l|}{$\begin{array}{l}\text { S: Piatelli } 2002 \\
\text { C: BioOss vs AUT }\end{array}$} \\
\hline & Graft type & & & & \\
\hline 01: microvessel density & & -0.10 & 1.45 & $-2.94,2.74$ & 0.945 \\
\hline \multicolumn{6}{|l|}{$\begin{array}{l}\text { S: Pikdoken } 2011 \\
\text { C: BioOss+AUT }(8 / 2) \text { vs BioOss }\end{array}$} \\
\hline & Graft type & & & & \\
\hline 01: 99mTc-MDP uptake (scintigrafic activity) & & 0.33 & 0.40 & $-0.45,1.11$ & 0.407 \\
\hline 02: \%new bone & & 1.54 & 0.99 & $-0.41,3.49$ & 0.121 \\
\hline 03: \%residual graft & & -2.55 & 2.95 & $-8.32,3.22$ & 0.387 \\
\hline 04: \%connective tissue & & 1.18 & 2.60 & $-3.91,6.27$ & 0.650 \\
\hline \multicolumn{6}{|l|}{$\begin{array}{l}\text { S: Tosta } 2013 \\
\text { C: BoneCeramic vs AUT }\end{array}$} \\
\hline & Graft type & & & & \\
\hline 01: \%new bone & & -7.33 & 2.40 & $-12.04,-2.62$ & 0.002 \\
\hline 02: \%connective tissue & & -25.82 & 2.39 & $-30.51,-21.14$ & $<0.001$ \\
\hline \multicolumn{6}{|l|}{$\begin{array}{l}\text { S: Wood } 2012 \\
\text { C: DFDBA vs FDBA }\end{array}$} \\
\hline & Graft type & & & & \\
\hline 01: \%new bone & & 13.79 & 4.97 & $4.04,23.54$ & 0.006 \\
\hline 02: \%residual graft & & -16.54 & 5.33 & $-26.98,-6.10$ & 0.002 \\
\hline 03: \%connective tissue & & 2.77 & 3.41 & $-3.91,9.45$ & 0.416 \\
\hline 04: bone height buccally & & -0.20 & 0.41 & $-0.99,0.59$ & 0.621 \\
\hline 05: bone height lingually & & 0.37 & 0.52 & $-0.66,1.40$ & 0.480 \\
\hline 06: bone width & & 0.09 & 0.59 & $-1.06,1.24$ & 0.879 \\
\hline 07: \%bone width & & 1.90 & 5.80 & $-9.47,13.27$ & 0.743 \\
\hline
\end{tabular}

MD, mean difference; SE, standard error; CI, confidence interval; O, outcome; est., estimate; Adj., adjusted;S, study; C, comparison; ALL, allograft; AUT, autograft; rhBMP-2/ACS, recombinant human bone morphogenetic protein-2 delivered on an Absorbable Collagen Sponge; HU, Hounsfield units; CT, computed tomography; rhGDF-5, recombinant human growth/differentiation factor-5; Bbw, buccal bone width; Pbw, palatal bone width; Mbh, mesial bone height; Dbh, distal bone height; 99mTc-MDP, 99mTc-methylene diphosphonate; DFDBA, demineralized freeze-dried bone allograft; FDBA, mineralized freeze-dried bone allograft. 
Appendix 11. Direct comparisons from the primary outcome network (mean differences and $95 \%$ confidence intervals). MD, mean difference; CI, confidence interval; $\mathrm{P}$, parallel; ESP, extraction socket preservation; C, cluster; SL, sinus lift; LRA, lateral ridge augmentation; AUT, autograft; ALL, allograft; SYN, synthetic bone graft; XEN, xenograft.

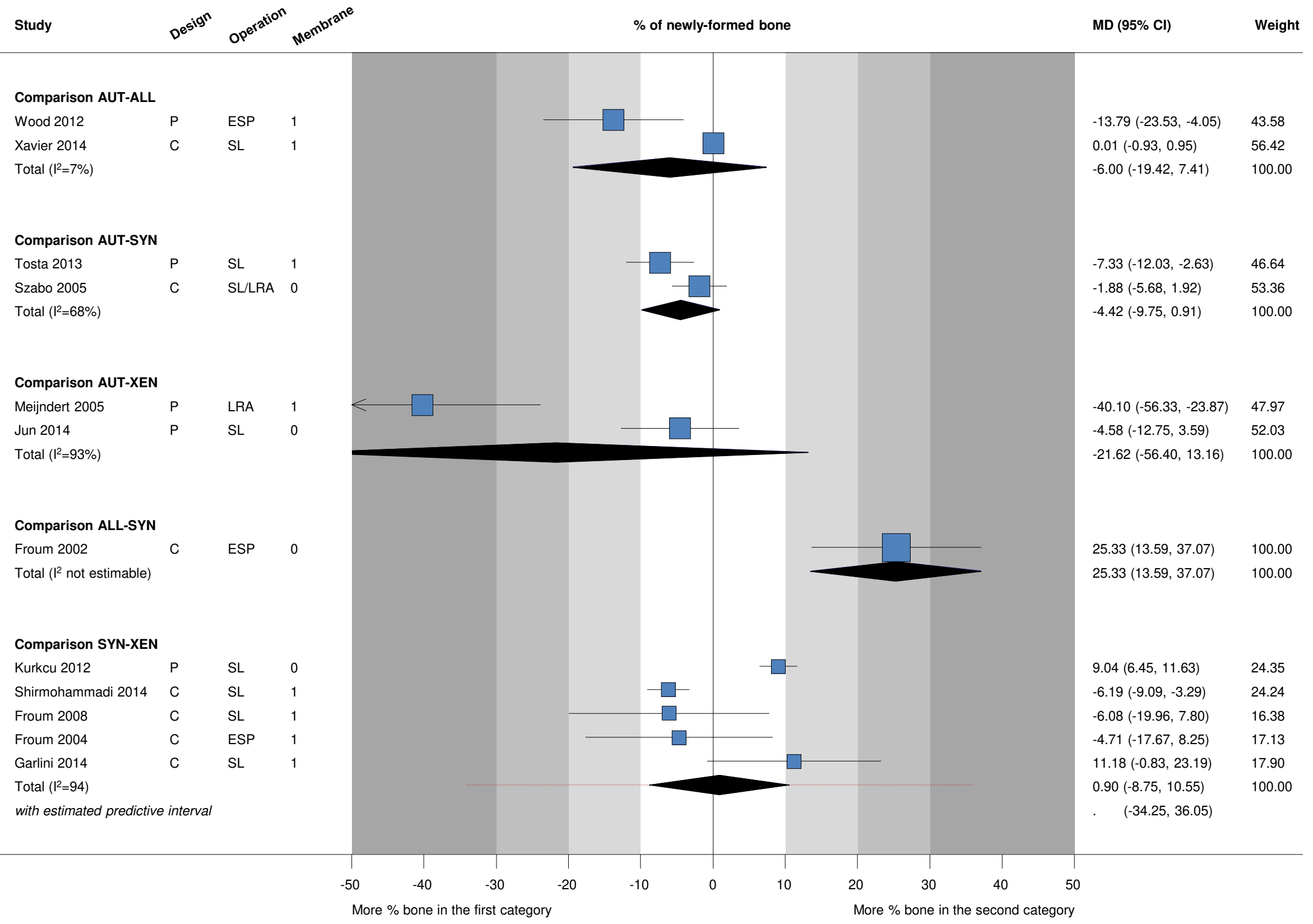


Appendix 12. Contribution plot of each direct comparison to the evidence network. AUT, autograft; ALL, allograft; SYN, synthetic bone graft; XEN, xenograft.

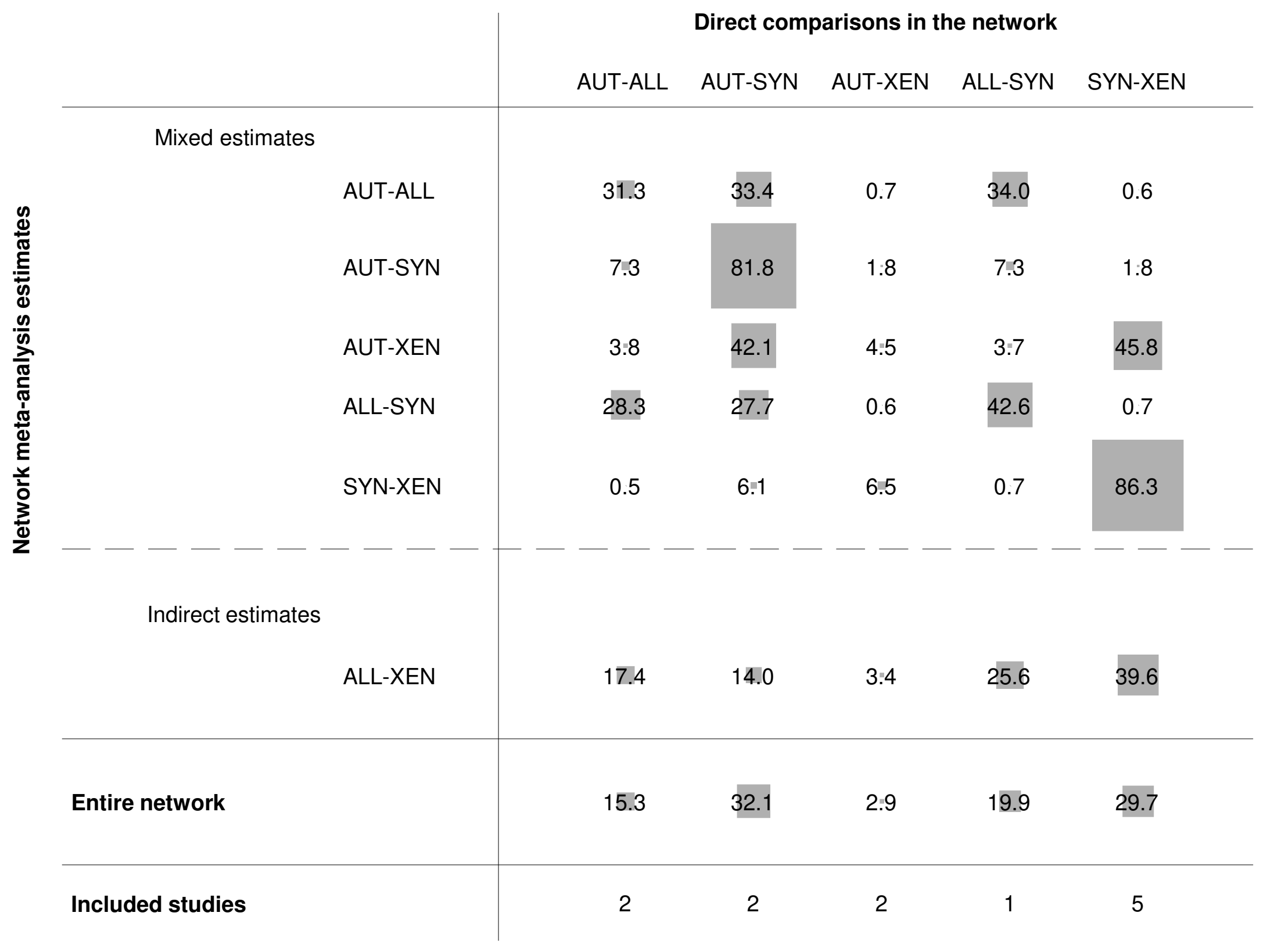


Appendix 13. Evaluation of transitivity across network in terms of similarities across comparisons. Presented are the mean patient ages (in years) and the mean sex distribution across the studies included in each comparison in the format: number of trials with provided data: mean (standard deviation)

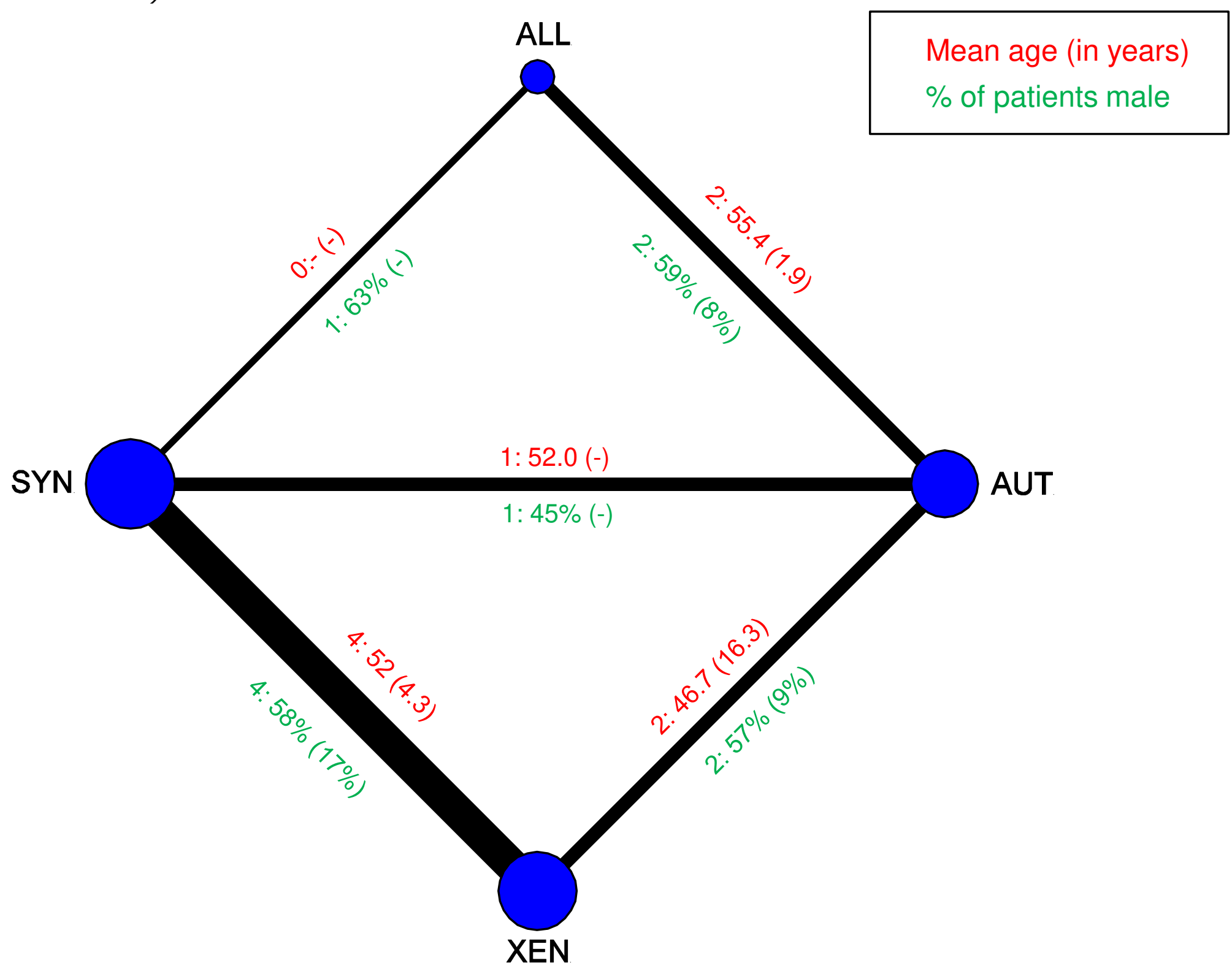


Appendix 14. League table with all direct (white) and mixed (light blue) comparisons from the primary

\begin{tabular}{|c|c|c|c|}
\hline AUT & $\begin{array}{c}-13.51 \\
(-28.26,1.24)\end{array}$ & $\begin{array}{c}-5.50 \\
(-17.42,6.41)\end{array}$ & $\begin{array}{c}-8.62 \\
(-21.53,4.28)\end{array}$ \\
\hline-6.00 & ALL & 8.01 & 4.89 \\
$(-19.42,7.41)$ & 25.33 & $-8.57,24.59)$ & $(-13.05,22.82)$ \\
\hline-4.42 & SYN & -3.12 \\
$(-9.75,0.91)$ & $(13.59,37.07)$ & $-13.34,7.10)$ \\
\hline-21.62 & - & $0.90(-8.75,10.55)$ & XEN \\
\hline
\end{tabular}

AUT, autograft; ALL, allograft; SYN, synthetic bone graft; XEN, xenograft. 
Appendix 15. Evaluation of inconsistency using loop-specific heterogeneity estimates. IF, inconsistency factor; SE, standard error; CI, confidence interval; AUT, autograft; ALL, allograft; SYN, synthetic bone graft; XEN, xenograft.

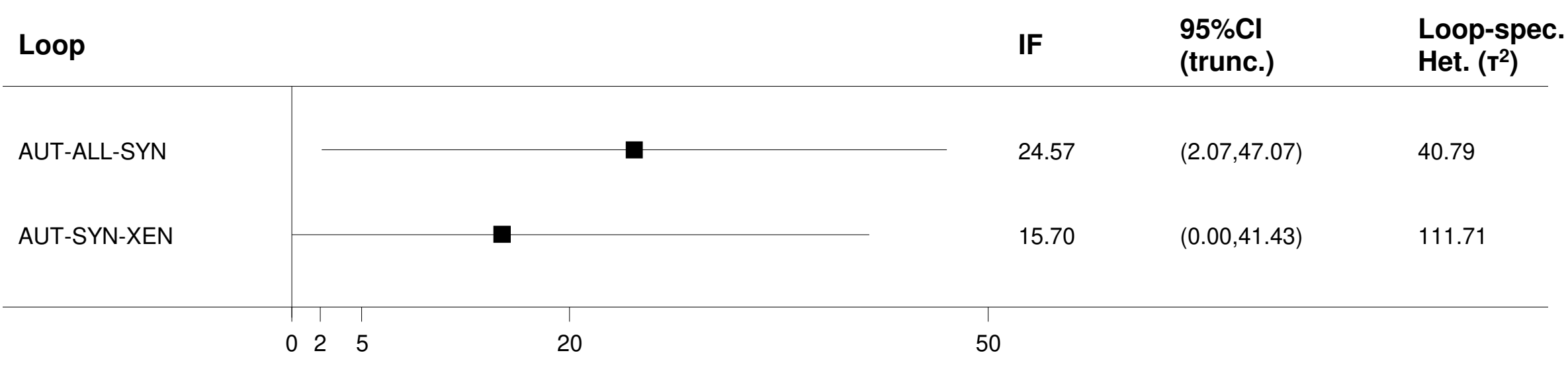

\begin{tabular}{ccccccc}
\hline Loop & IF & SE for IF & $\mathbf{z}$ & P value & $\mathbf{9 5 \%}$ Cl & Loop-specific tau $^{2}$ \\
\hline AUT-ALL-SYN & 24.57 & 11.48 & 2.14 & 0.032 & $2.07,47.07$ & 40.79 \\
AUT-SYN-XEN & 15.70 & 13.13 & 1.20 & 0.232 & $0.00,41.43$ & 111.71 \\
\hline
\end{tabular}


Appendix 16. Node-splitting analysis of direct and indirect comparisons.

\begin{tabular}{|c|c|c|}
\hline Direct & Indirect & Difference \\
\hline
\end{tabular}

\begin{tabular}{|c|c|c|c|l|l|c|c|}
\hline Side & \multicolumn{1}{c}{ MD } & SE & \multicolumn{1}{c|}{ MD } & \multicolumn{1}{c|}{ SE } & \multicolumn{1}{c|}{ MD } & SE & P \\
\hline AUT-ALL & -6.15 & 7.55 & -33.63 & 12.91 & 27.48 & 14.95 & 0.066 \\
\hline AUT-SYN & -4.59 & 9.16 & -6.48 & 9.11 & 1.89 & 12.92 & 0.884 \\
\hline AUT-XEN & -19.60 & 9.07 & 1.57 & 8.55 & -21.16 & 12.49 & 0.090 \\
\hline ALL-SYN & 25.21 & 11.76 & -3.55 & 9.47 & 28.76 & 15.11 & 0.057 \\
\hline
\end{tabular}

\begin{tabular}{|l|l|l|l|l|l|l|l|}
\hline ALL-SYN & 25.21 & 11.76 & -3.55 & 9.47 & 28.76 & 15.11 & 0.057 \\
\hline
\end{tabular}

\begin{tabular}{l|l|l|l|l|l|l|l}
\hline SYN-XEN & 0.83 & 5.43 & -20.15 & 11.51 & 20.97 & 12.71 & 0.099 \\
\hline
\end{tabular}

MD, mean difference; SE, standard error; AUT, autograft; ALL, allograft; SYN,

synthetic bone graft; XEN, xenograft. 
Appendix 17. Results of the original analysis and of network meta-regressions including possible confounders (using the ML method instead of the original REML one). Factors with considerable effects were re-analyzed with the original REML method and treatment rankings adjusted for this covariate were calculated.

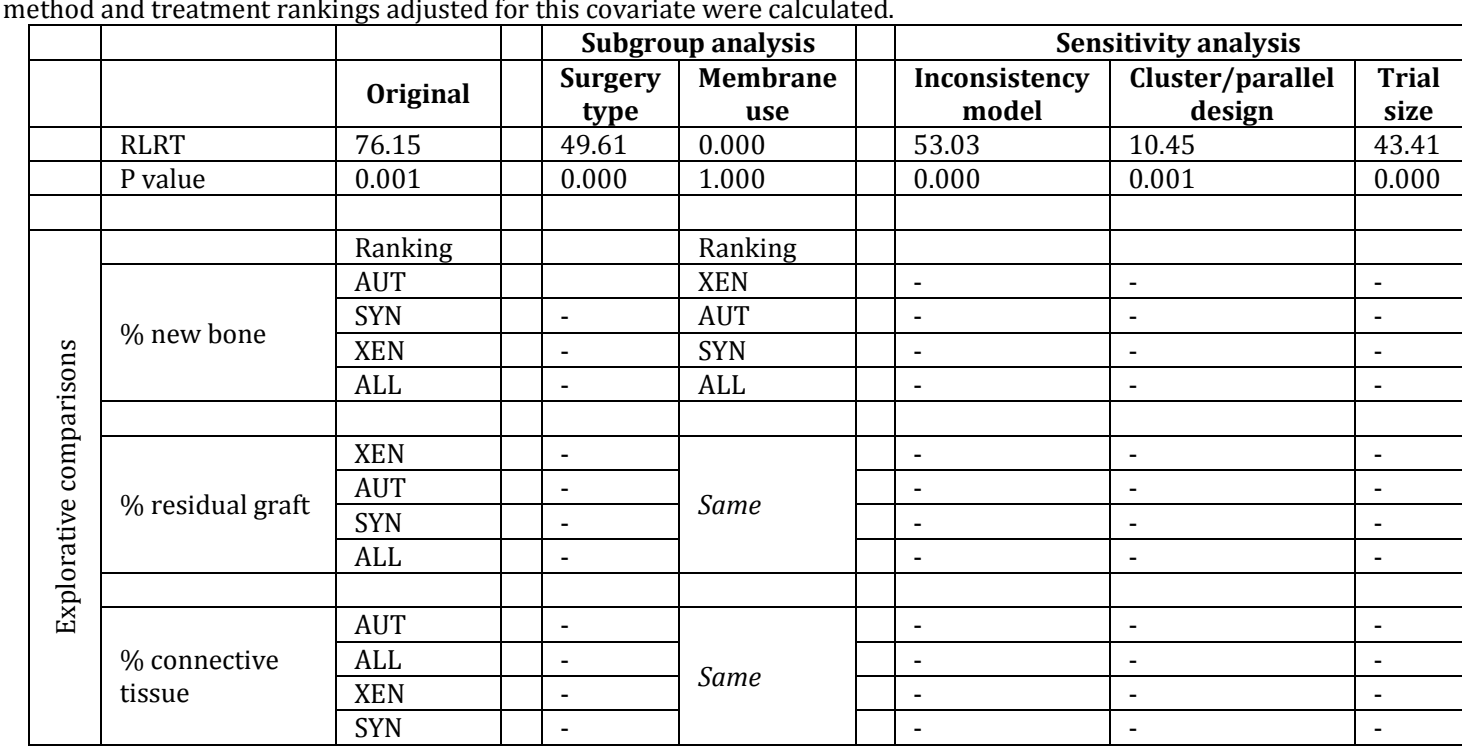

ML, maximum likelihood; REML, restricted maximum likelihood; RLRT, restricted likelihood ratio testing; AUT, autograft; ALL, allograft; SYN, synthetic bone graft; XEN, xenograft. 
Appendix 18. Details for the GRADE assessment for each pairwise comparison and the evidence network.

\begin{tabular}{|c|c|c|c|c|c|}
\hline Comparison & Study limitations & Indirectness & Inconsistency & Imprecision & Publication bias \\
\hline$A B$ & $\begin{array}{l}\text { No downgrade; less than } 10 \% \text { in } \\
\text { high risk of bias }\end{array}$ & $\begin{array}{l}\text { No robust reason to } \\
\text { downgrade }\end{array}$ & $\begin{array}{l}\text { Node-splitting yielded an almost statistically significant } \\
\text { difference between direct and indirect estimates, which } \\
\text { influenced however their magnitude, but not their } \\
\text { direction; additionally, no source of heterogeneity was } \\
\text { identified through network meta-regression; decided } \\
\text { not to downgrade }\end{array}$ & $\begin{array}{l}\text { Downgrade for imprecision; predictive } \\
\text { intervals for treatment effect include } \\
\text { effects that would have different } \\
\text { interpretations }\end{array}$ & $\begin{array}{l}\text { No robust reason to } \\
\text { downgrade }\end{array}$ \\
\hline$A C$ & $\begin{array}{l}\text { No downgrade; less than } 10 \% \text { in } \\
\text { high risk of bias }\end{array}$ & $\begin{array}{l}\text { No robust reason to } \\
\text { downgrade }\end{array}$ & No robust evidence of inconsistency & $\begin{array}{l}\text { Downgrade for imprecision; predictive } \\
\text { intervals for treatment effect include } \\
\text { effects that would have different } \\
\text { interpretations }\end{array}$ & $\begin{array}{l}\text { No robust reason to } \\
\text { downgrade }\end{array}$ \\
\hline $\mathrm{AD}$ & $\begin{array}{l}\text { Downgraded by two levels; } \\
\text { almost half of the evidence in high } \\
\text { risk of bias }\end{array}$ & $\begin{array}{l}\text { No robust reason to } \\
\text { downgrade }\end{array}$ & $\begin{array}{l}\text { Node-splitting yielded an almost statistically significant } \\
\text { difference between direct and indirect estimates, which } \\
\text { influenced both their magnitude and their direction; } \\
\text { additionally, no source of heterogeneity was identified } \\
\text { through network meta-regression; decided to } \\
\text { downgrade by one }\end{array}$ & $\begin{array}{l}\text { Downgrade for imprecision; predictive } \\
\text { intervals for treatment effect include } \\
\text { effects that would have different } \\
\text { interpretations }\end{array}$ & $\begin{array}{l}\text { No robust reason to } \\
\text { downgrade }\end{array}$ \\
\hline $\mathrm{BC}$ & $\begin{array}{l}\text { No downgrade; less than } 10 \% \text { in } \\
\text { high risk of bias }\end{array}$ & $\begin{array}{l}\text { No robust reason to } \\
\text { downgrade }\end{array}$ & $\begin{array}{l}\text { Node-splitting yielded an almost statistically significant } \\
\text { difference between direct and indirect estimates, which } \\
\text { influenced both their magnitude and their direction; } \\
\text { additionally, no source of heterogeneity was identified } \\
\text { through network meta-regression; decided to } \\
\text { downgrade by one }\end{array}$ & $\begin{array}{l}\text { Downgrade for imprecision; predictive } \\
\text { intervals for treatment effect include } \\
\text { effects that would have different } \\
\text { interpretations }\end{array}$ & $\begin{array}{l}\text { No robust reason to } \\
\text { downgrade }\end{array}$ \\
\hline BD & $\begin{array}{l}\text { Downgrade by one level; one third } \\
\text { of the evidence in high risk of bias }\end{array}$ & $\begin{array}{l}\text { No robust reason to } \\
\text { downgrade }\end{array}$ & Only indirect evidence available & $\begin{array}{l}\text { Downgrade for imprecision; predictive } \\
\text { intervals for treatment effect include } \\
\text { effects that would have different } \\
\text { interpretations }\end{array}$ & $\begin{array}{l}\text { No robust reason to } \\
\text { downgrade }\end{array}$ \\
\hline $\mathrm{CD}$ & $\begin{array}{l}\text { Downgraded by two levels; most } \\
\text { evidence in high risk of bias }\end{array}$ & $\begin{array}{l}\text { No robust reason to } \\
\text { downgrade }\end{array}$ & $\begin{array}{l}\text { Node-splitting yielded an almost statistically significant } \\
\text { difference between direct and indirect estimates, which } \\
\text { influenced both their magnitude and their direction; } \\
\text { additionally, no source of heterogeneity was identified } \\
\text { through network meta-regression; decided to } \\
\text { downgrade by one }\end{array}$ & $\begin{array}{l}\text { Downgrade for imprecision; predictive } \\
\text { intervals for treatment effect include } \\
\text { effects that would have different } \\
\text { interpretations }\end{array}$ & $\begin{array}{l}\text { No robust reason to } \\
\text { downgrade }\end{array}$ \\
\hline Ranking & $\begin{array}{l}\text { Downgrade by one level; one third } \\
\text { of the evidence in high risk of bias }\end{array}$ & $\begin{array}{l}\text { No robust reason to } \\
\text { downgrade; membrane use } \\
\text { could possibly have a } \\
\text { modifying effect, but this } \\
\text { was discarded due to lack of } \\
\text { credibility }\end{array}$ & $\begin{array}{l}\text { Global } \mathrm{Q} \text { test for inconsistency was almost statistically } \\
\text { significant }(\mathrm{P}=0.061) \text {; however, model fit with the } \\
\text { design-by-treatment model was not greatly improved } \\
\text { and treatment ranking was relatively robust; decided } \\
\text { not to downgrade }\end{array}$ & No robust reason to downgrade & $\begin{array}{l}\text { No robust reason to } \\
\text { downgrade }\end{array}$ \\
\hline
\end{tabular}

A, autograft; $B$, alloplast: $C$ synthetic bone graft; $D$, xenograft. 
Appendix 19. Study limitations for each network estimate for each pairwise comparison and for the whole network of \%new bone. A, autograft; B, allograft; C, synthetic bone graft; D, xenograft.
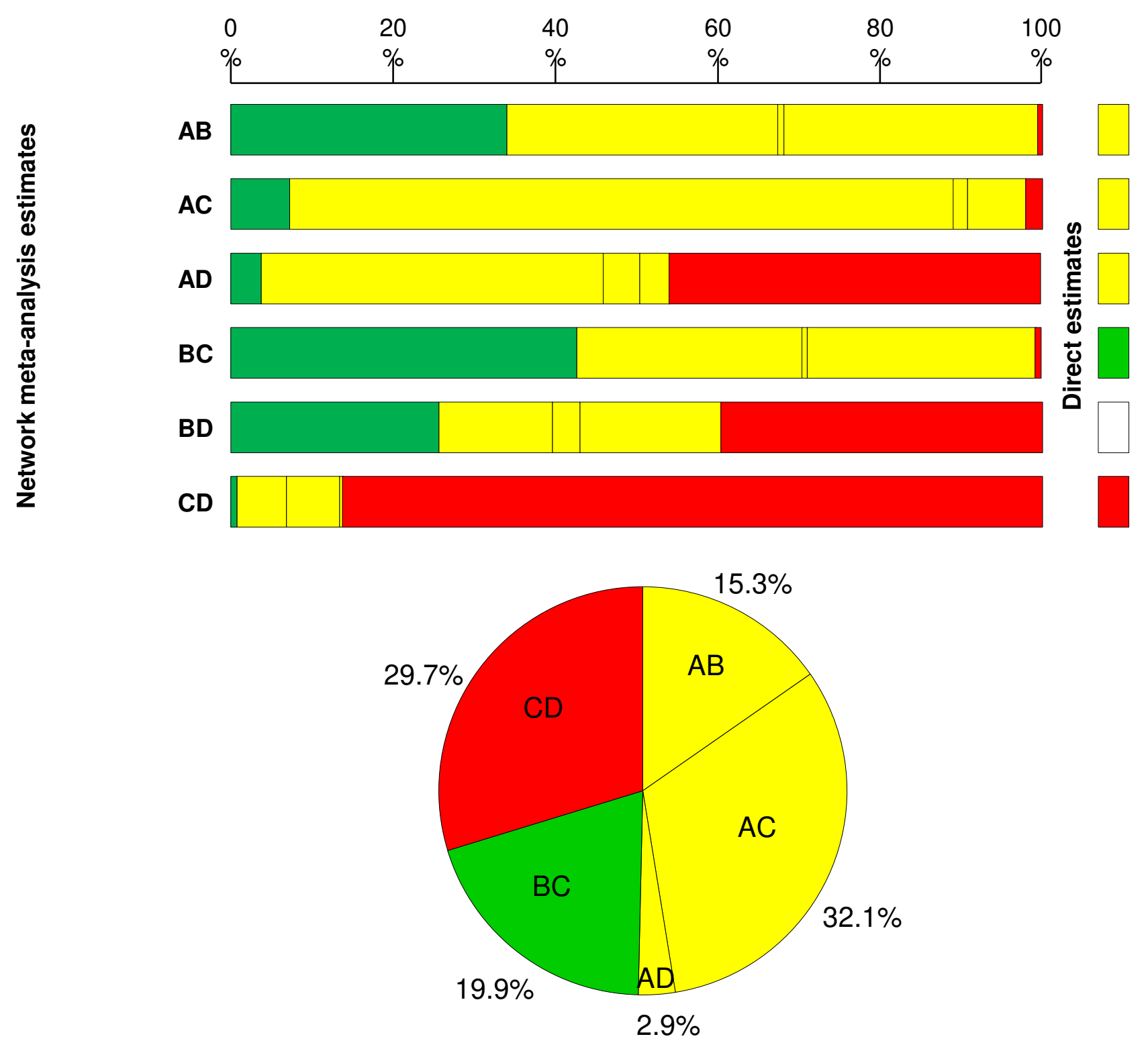
Appendix 20. Alternate network geometry. ALL, allograft; AUT, autograft; XENO, xenolograft.

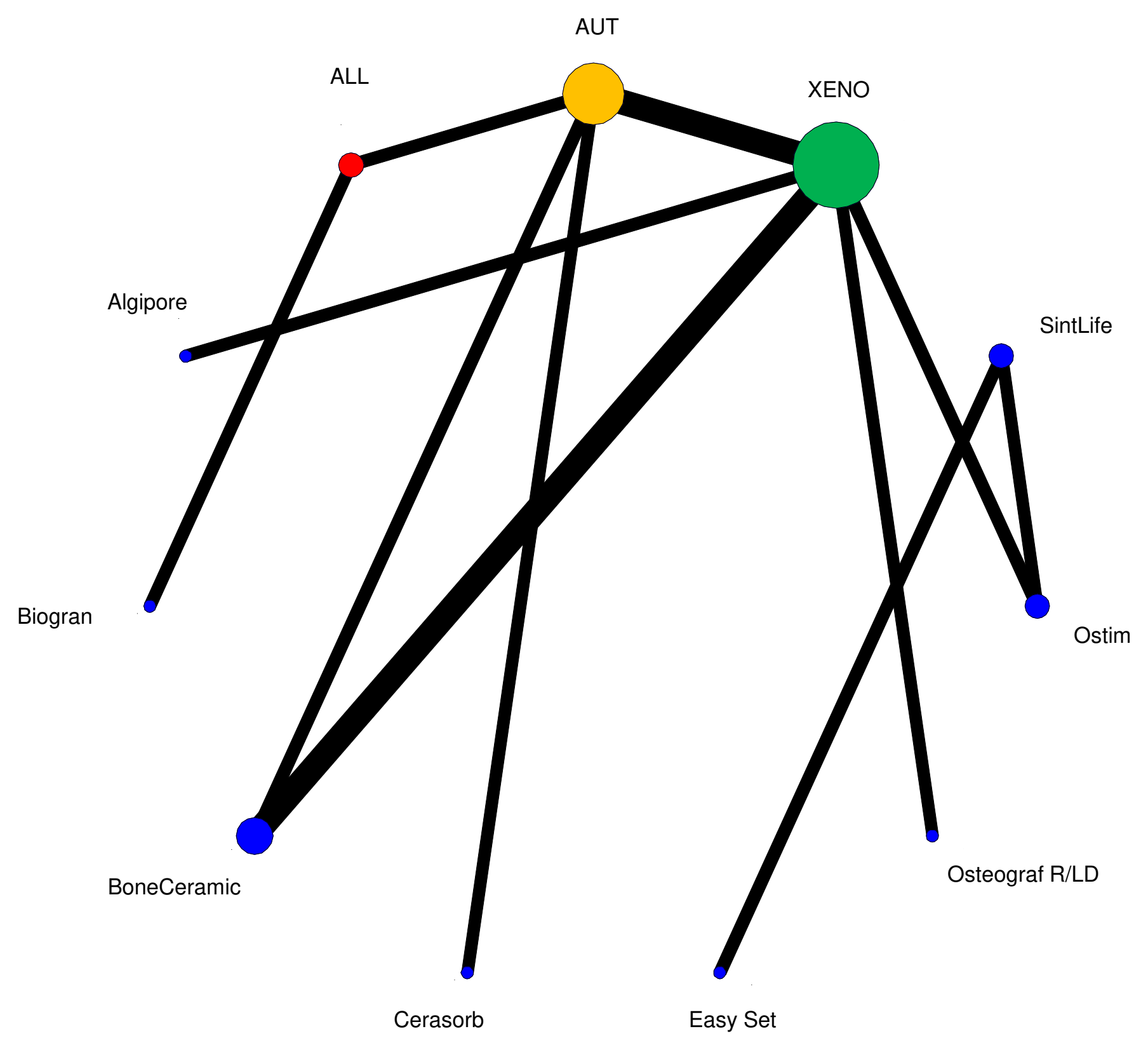


Appendix 21. Plots of the surface under the cumulative ranking curves for all treatments in the primary outcome alternative network. AUT, autograft; ALL, allograft; XEN, xenograft.
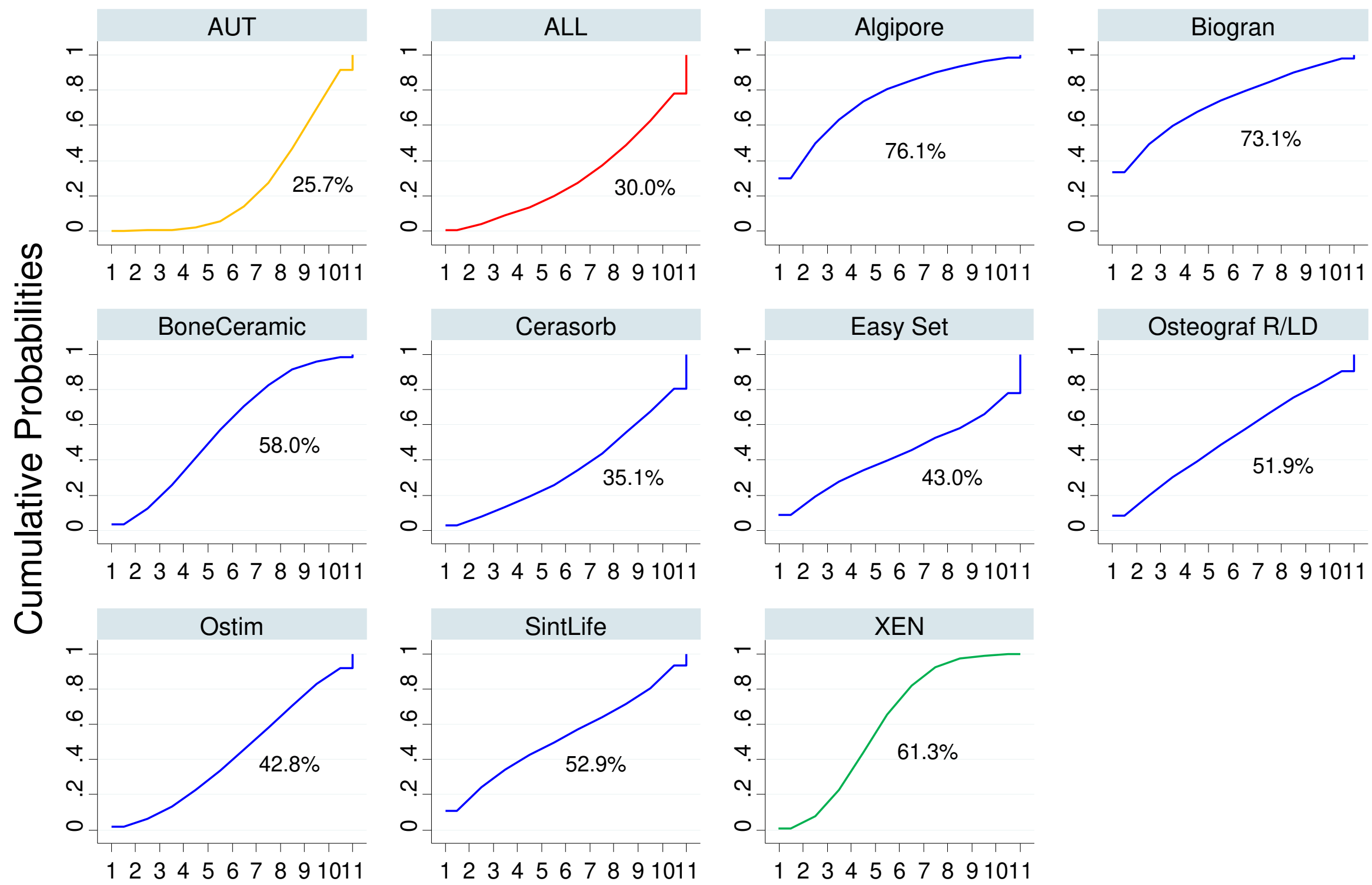

\section{Rank}


Appendix 22. Investigation of heterogeneity sources: effect of covariates on the $\%$ of new bone from individual patient

\begin{tabular}{|l|l|l|l|c|c|c|}
\hline \multicolumn{1}{|c|}{ Factor } & \multicolumn{1}{|c|}{ Comparison } & Studies & \multicolumn{1}{|c|}{ MD (95\% CI) } & \multicolumn{1}{|c|}{$\mathbf{P}$} & $\mathbf{I}^{\mathbf{2}} \mathbf{( 9 5 \%}$ UI) & $\mathbf{9 5 \%}$ PrI \\
\hline Patient age & One yr increase & 4 & $-0.07(-0.45,0.31)$ & 0.707 & $71 \%(0 \%, 88 \%)$ & $-1.66,1.52$ \\
\hline Patient sex & Male-female & 3 & $4.79(-3.40,12.98)$ & 0.252 & $53 \%(0 \%, 85 \%)$ & $-81.14,90.72$ \\
\hline Healing time & One mo increase & 4 & $2.06(-3.03,7.15)$ & 0.427 & $26 \%(0 \%, 76 \%)$ & $-13.92,18.04$ \\
\hline Membrane type & EPTFE-ADMA & 1 & $-13.64(-26.67,-0.61)$ & 0.040 & - & - \\
\hline
\end{tabular}

MD, mean difference; $\mathrm{CI}$, confidence interval; UI, uncertainty interval; PrI, predictive interval; EPTFE, expanded

polytetrafluoroethylene; ADMA, acellular dermal matrix allograft. 
Appendix 23. Direct estimates for the secondary histomorphometric outcomes.

\begin{tabular}{|l|l|l|l|l|l|l|}
\hline \multicolumn{7}{|c|}{ Connective tissue } \\
\hline Comparison & Studies & MD $(95 \% \mathrm{CI})$ & $\mathrm{I}^{2}(95 \% \mathrm{UI})$ & tau $^{2}$ & $95 \%$ PrI & $\mathrm{P}$ \\
\hline AUT-ALL & 2 & $1.76(-2.29 .5 .80)$ & $0 \%(-)$ & 0.00 & - & 0.395 \\
\hline AUT-SYN & 2 & $14.67(-7.10,36.43)$ & $98 \%(-)$ & 241.96 & - & 0.187 \\
\hline AUT-XEN & 2 & $-1.24(-11.19,8.71)$ & $0 \%(-)$ & 0.00 & - & 0.807 \\
\hline ALL-SYN & 1 & $17.73(5.70,29.76)$ & - & 0.00 & - & 0.004 \\
\hline SYN-XEN & 5 & $1.00(-5.50,7.50)$ & $69 \%(0 \%, 86 \%)$ & 34.42 & $-20.45,22.45$ & 0.763 \\
\hline \multicolumn{7}{|c|}{ Residual graft } \\
\hline \multicolumn{7}{|c|}{} \\
\hline AUT-ALL & 2 & $8.14(-6.87,23.15)$ & $85 \%(-)$ & & \\
\hline AUT-SYN & 1 & $5.50(3.52,7.48)$ & - & 100.77 & - & 0.288 \\
\hline AUT-XEN & 1 & $-2.12(-11.74,7.50)$ & - & 0.00 & - & $<0.001$ \\
\hline ALL-SYN & 1 & $-9.57(-12.75,-6.39)$ & - & 0.00 & - & 0.666 \\
\hline SYN-XEN & 5 & $-1.96(-13.54,9.62)$ & $95 \%(91 \%, 96 \%)$ & 160.53 & $-46.45,9.62$ & 0.740 \\
\hline
\end{tabular}

MD, mean difference; CI, confidence interval; UI, uncertainty interval; PrI, predictive interval; AUT, autograft; ALL, allograft; SYN, synthetic bone graft; XEN, xenograft. 
Appendix 24. Network plots and contribution plots for the secondary histomorphometric outcomes. A, AUT (autograft); B, ALL (allograft); C, SYN (synthetic bone graft); D, XEN (xenograft).
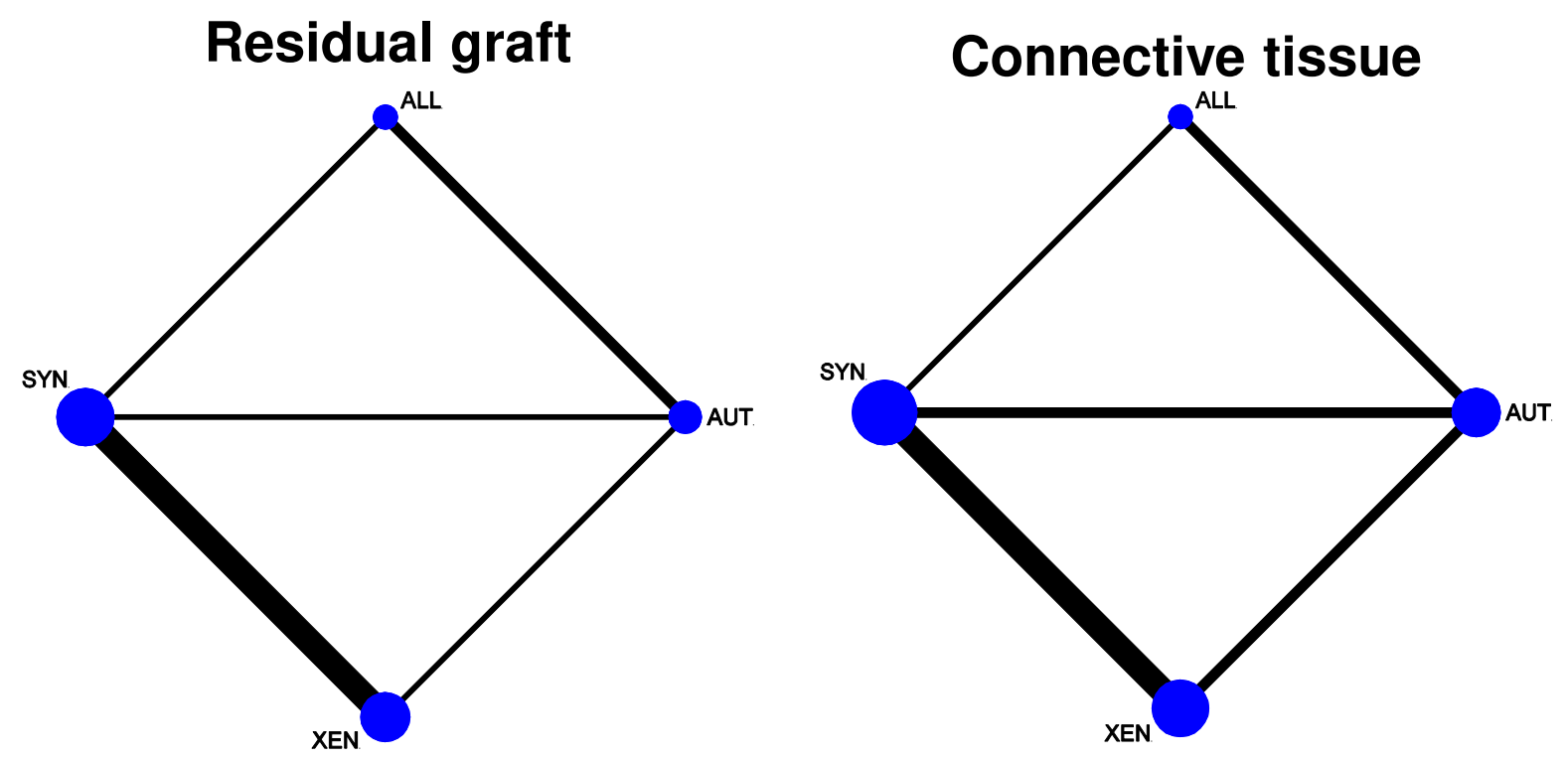

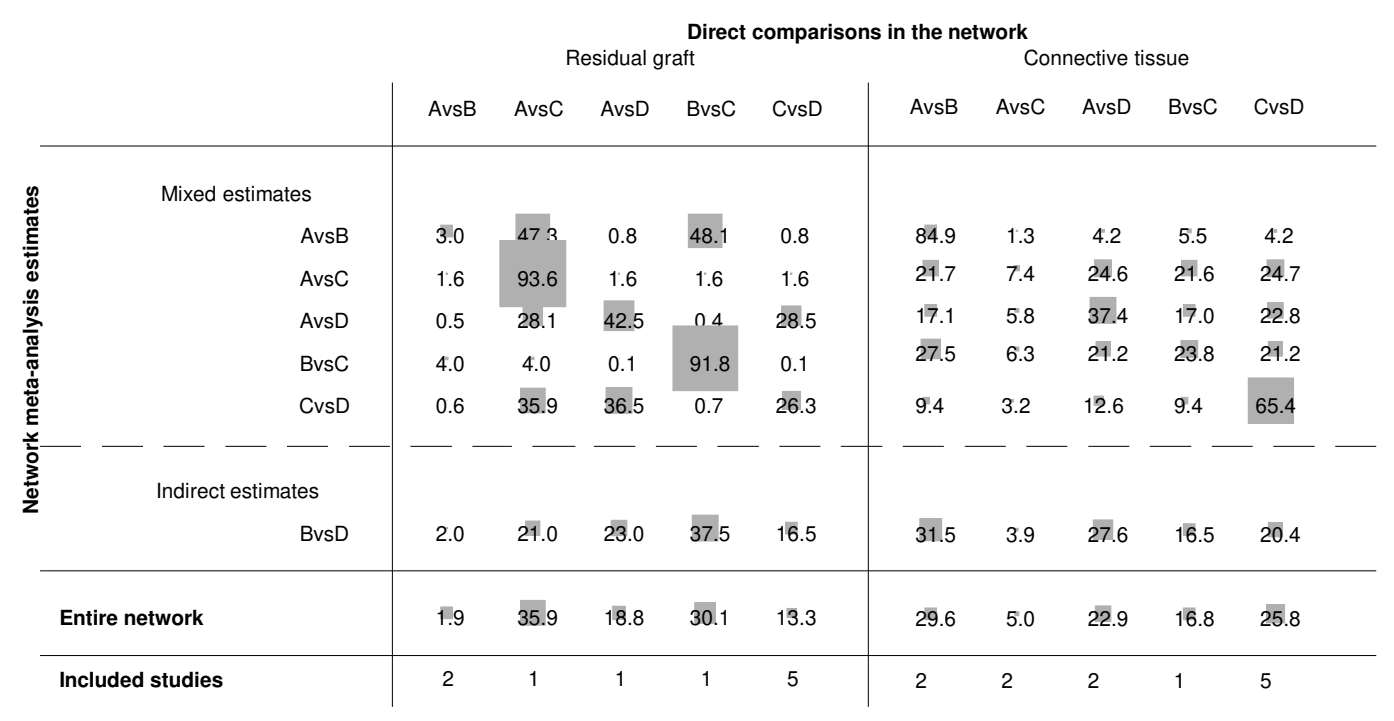


Appendix 25. League table with all mixed comparisons from the primary outcome network (mean differences and 95\% confidence intervals.

\begin{tabular}{|c|c|c|c|c|c|c|c|}
\hline \multicolumn{4}{|c|}{ Residual graft } & \multicolumn{4}{|c|}{ Connective tissue } \\
\hline AUT & $\begin{array}{c}9.23 \\
(-3.85,22.32)\end{array}$ & $\begin{array}{c}1.73 \\
(-11.13,14.60)\end{array}$ & $\begin{array}{c}-0.56 \\
(-14.41,13.28)\end{array}$ & AUT & $\begin{array}{c}-0.51 \\
(-11.54,10.52)\end{array}$ & $\begin{array}{c}10.54 \\
(1.33,19.74)\end{array}$ & $\begin{array}{c}8.20 \\
(-2.14,18.54)\end{array}$ \\
\hline & ALL & $\begin{array}{c}-7.50 \\
(-22.30,7.30)\end{array}$ & $\begin{array}{c}-9.80 \\
(-26.08,6.48)\end{array}$ & & ALL & $\begin{array}{c}11.05 \\
(-1.62,23.71)\end{array}$ & $\begin{array}{c}8.71 \\
(-5.16,22.59)\end{array}$ \\
\hline & & SYN & $\begin{array}{c}-2.30 \\
(-11 \cdot 36,6 \cdot 76)\end{array}$ & & & SYN & $\begin{array}{c}-2.34 \\
(-10.18,5.51)\end{array}$ \\
\hline & & & XEN & & & & XEN \\
\hline
\end{tabular}

AUT = autograft; ALL = allograft; SYN = synthetic bone graft; XEN = xenograft. 
Appendix 26. Ranking of various grafts according to the networks for the secondary histomorphometric outcomes of \% residual graft and \% connective tissue. AUT, autograft; ALL, allograft; SYN, synthetic bone graft; XEN, xenograft; SUCRA, surface under the cumulative ranking curve.

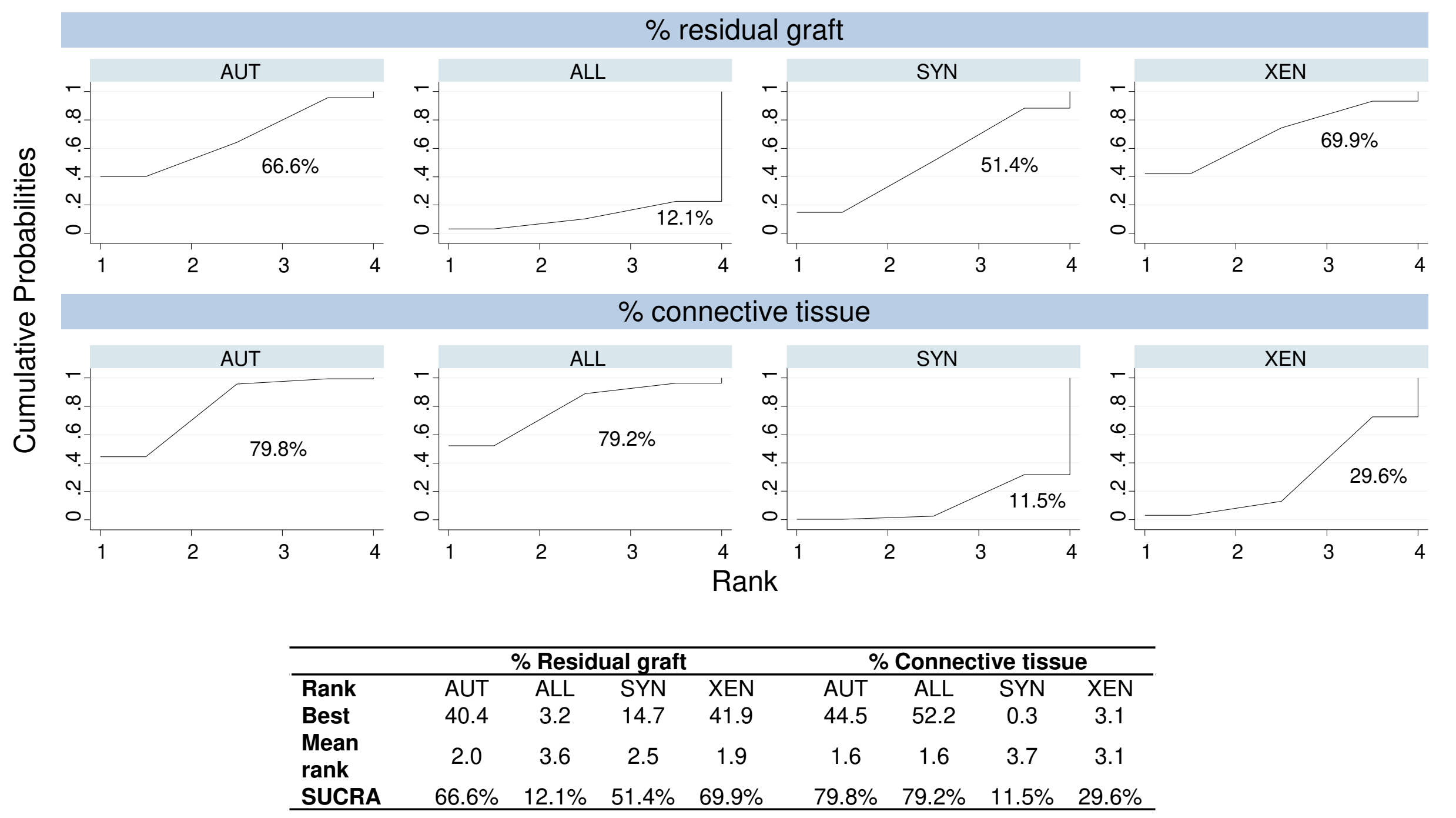


Appendix 27. Clustered ranking plot of the graft network based on cluster analysis of SUCRA values for two different outcomes: \% new bone and \% residual graft. AUT, autograft; SYN, synthetic bone graft; XEN, xenograft; ALL, allograft.

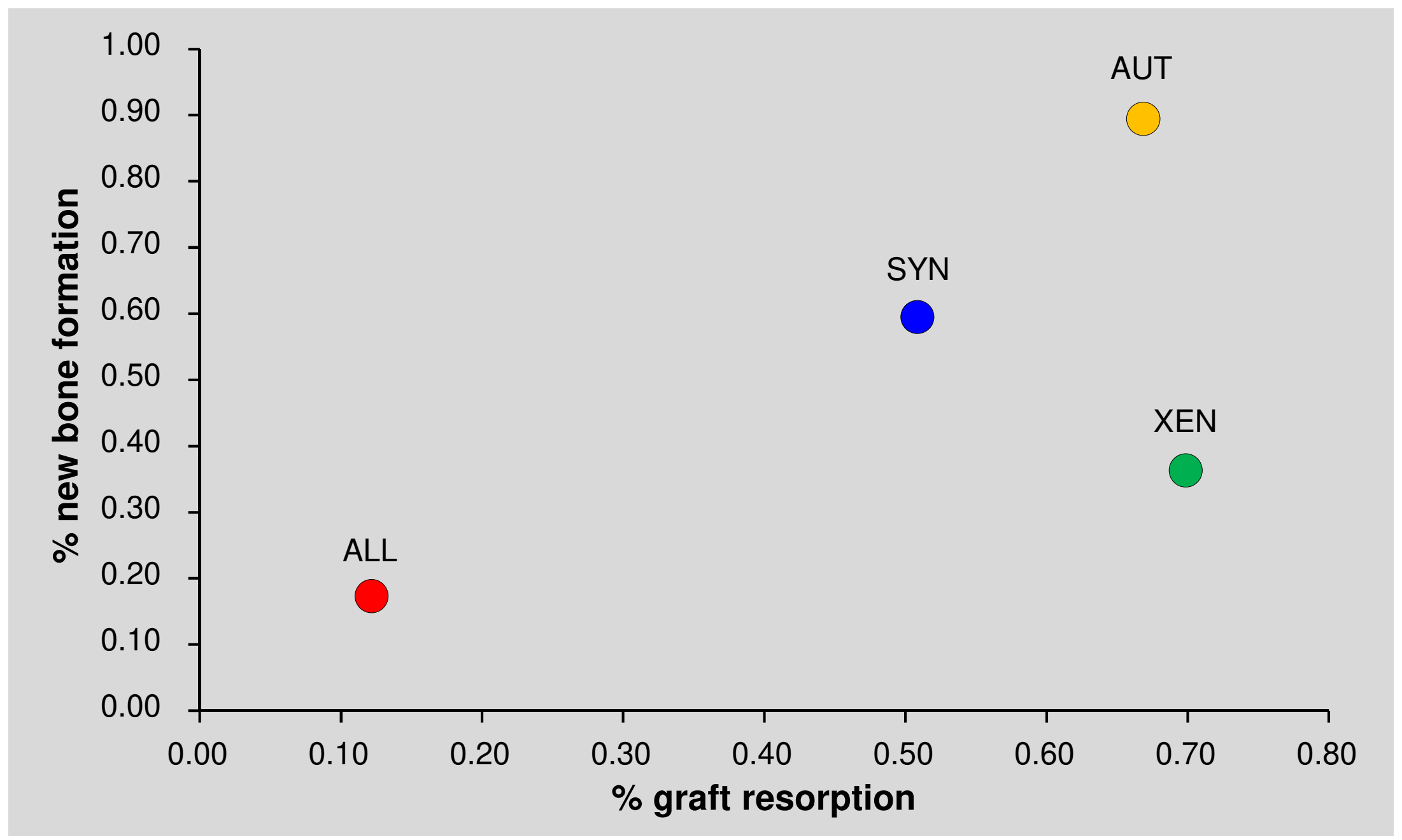


Appendix 28. Node-splitting analysis of direct and indirect comparisons for the secondary histomorphometric outcomes.

\begin{tabular}{|l|l|l|l|l|l|l|l|l|l|l|l|l|l|l|l|}
\hline & \multicolumn{9}{|c|}{ Residual graft } & \multicolumn{3}{c|}{ Connective tissue } \\
\hline & \multicolumn{2}{|c|}{ Direct } & \multicolumn{1}{|c|}{ Indirect } & \multicolumn{3}{c|}{ Difference } & \multicolumn{3}{c|}{ Direct } & \multicolumn{3}{c|}{ Indirect } & \multicolumn{2}{c|}{ Difference } \\
\hline Side & MD & SE & MD & SE & MD & SE & P & MD & SE & MD & SE & MD & SE & P \\
\hline AUT-ALL & 8.25 & 8.33 & 11.94 & 13.61 & -3.69 & 15.97 & 0.817 & 1.95 & 6.62 & -8.51 & 11.83 & 10.46 & 13.56 & 0.440 \\
\hline AUT-SYN & 5.50 & 1.00 & -0.77 & 8.90 & 6.27 & 14.15 & 0.658 & & 14.57 & 6.32 & 5.42 & 7.09 & 9.15 & 9.50 & 0.336 \\
\hline AUT-XEN & -2.12 & 12.09 & 0.37 & 9.53 & -2.49 & 15.39 & 0.872 & & -1.13 & 7.43 & 15.49 & 6.32 & -16.62 & 9.76 & 0.088 \\
\hline ALL-SYN & -9.57 & 11.18 & -5.37 & 11.64 & -4.19 & 16.14 & 0.795 & & 17.71 & 10.78 & 6.97 & 8.44 & 10.74 & 13.70 & 0.433 \\
\hline SYN-XEN & -1.97 & 5.23 & -4.86 & 14.83 & 2.89 & 15.72 & 0.854 & & 0.74 & 4.01 & -16.83 & 8.96 & 17.56 & 9.80 & 0.073 \\
\hline
\end{tabular}

MD, mean difference; SE, standard error; AUT, autograft; ALL, allograft; SYN, synthetic bone graft; XEN, xenograft . 
Crespi R, Cappare P, Gherlone E. Comparison of magnesium-enriched hydroxyapatite and porcine bone in human extraction socket healing: a histologic and histomorphometric evaluation. Int J Oral Maxillofac Imp 2011;26:1057-62.

grafts: bone from the iliac crest versus bovine anorganic bone. Eur I Implantol 2008;1:183-98. Kotsakis GA, Salama M, Chrepa V, Hinrichs JE, Gaillard P. A randomized, blinded, controlled clince

phosphosilicate putty bone substitutes for socket preservation. Int J Oral Maxillofac Imp 2014;29:141-51.

Molly 2008 Periodontol 2008;79:1108-15.

2014

autogenous bone used for lateral ridge augmentation. A randomized and controlled clin

Schmitt

Raghoebar GM, Schortinghuis J, Liem RS, Ruben JL, van der Wal JE, Vissink A. Does platelet-rit

Raghoebar GM, Schortinghuis J, Liem RS, Ruben JL, van der Wal JE, Vissink A. D
augmentation of the maxillary sinus floor? Clin Oral Imp Res 2005;16:349-56.

$10 \begin{aligned} & \text { Schmitt } \\ & 2013\end{aligned}$

Schmitt CM, Doering H, Schmidt T, Lutz R, Neukam FW, Schlegel KA. Histological

1 Wagner

with a biphasic calcium phosphate combined with fibrin sealant in maxillary

Wiltfang J, Schlegel KA, Schultze-Mosgau S, Nkenke E, Zimmermann R, Kessler P. Sinus floor augmentation with beta-tricalciumphosphate (beta-TCP): does platelet-rich

plasma promote its osseous integration and degradation? Clin Oral Imp Res 2003;14:213-8.

-Cannizzaro G, Felice P, Leone M, Viola P, Esposito M. Early loading of implants in the atrophic posterior maxilla: lateral sinus lift with autogenous bone and Bio-Oss

versus crestal mini sinus lift and 8-mm hydroxyapatite-coated implants. A randomised controlled clinical trial. Eur J Oral Implantol 2009;2:25-38.

-Cannizzaro G, Felice P, Minciarelli AF, Leone M, Viola P, Esposito M. Early implant loading in the atrophic posterior maxilla: 1-stage lateral versus crestal sinus lift and 8 mm hydroxyapatite-coated implants. A 5-year randomised controlled trial. Eur J Oral Implantol 2013;6:13-25.

-Esposito M, Cannizzaro G, Soardi E, Pellegrino G, Pistilli R, Felice P. A 3-year post-loading report of a randomised controlled trial on the rehabilitation of posterior

atrophic mandibles: short implants or longer implants in vertically augmented bone? Eur J Oral Implantol 2011;4:301-311.

Esposito M, Cannizzaro G, Soardi E, Pistilli R, Piattelli M, Corvino V, Felice P. Posterior atrophic jaws rehabilitated with prostheses supported by $6 \mathrm{~mm}$-long, $4 \mathrm{~mm}$-wide

implants or by longer implants in augmented bone. Preliminary results from a pilot randomised controlled trial. Eur J Oral Implantol 2012;5:19-33.

-Esposito M, Piattelli M, Pistilli R, Pellegrino G, Felice P. Sinus lift with guided bone regeneration or anorganic bovine bone: 1-year post-loading results of a pilot

randomised clinical trial. Eur J Oral Implantol 2010;3:297-305.

-Felice P, Scarano A, Pistilli R, Checchi L, Piattelli M, Pellegrino G, Esposito M. A comparison of two techniques to augment maxillary sinuses using the lateral window approach: rigid synthetic resorbable barriers versus anorganic bovine bone. Five-month post-loading clinical and histological results of a pilot randomised controlled clinical trial. Eur J Oral Implantol 2009;2:293-306.

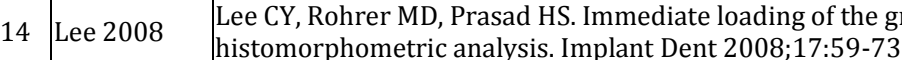


Appendix 30. Additional information regarding this systematic review.

\section{Author contributions}

SNP conceived the idea and wrote the first draft of the protocol. SNP, PNP, JD, WG revised the protocol. SNP performed the literature searches, extracted search hits, and did screening by title. SNP, PNP, and JD did study selection by abstract and full-text, did data extraction, and assessed the risk of bias in triplicate, while WG resolved any conflicts that arose. SNP handled communications with trialists, performed the statistical analysis (individual patient data processing, pairwise and network meta-analyses), and wrote the first draft of the manuscript. SNP, PNP, JD, and WG assisted in the interpretation of the results and revised the manuscript draft. SNP submitted the manuscript, is the guarantor and responsible for the accuracy of the data and for future updates of the review.

Post hoc changes to the protocol

- Smoking was not tested in the investigation for heterogeneity sources, as during piloting of the literature, strong evidence of impaired wound and bone healing was not found for smoking from re-analysis of raw data and was decided that this did not pertain to uninterrupted physiological graft healing.

- The method of measuring the outcome was not tested in the investigation for heterogeneity sources, as all studies used similar procedures.

- Many secondary outcomes listed in the protocol not pertaining to histomorphometry were not included in the review. Due to the heavy number of reported outcomes, which would make this review difficult to present and read, we focused only on the primary outcome (histomorphometrical \%new bone) and the two most often-reported histomorphometrical secondary outcomes from the protocol (\%residual graft and \%connective tissue). All outcomes however reported from include trials are analyzed and reported in Appendix 10.

- We had planned to restrict analyses to studies with use of membrane and a minimum of 4 months of uninterrupted healing. As however no differences were found for membrane use from our analyses and all studies had 6 or more months of healing, this was discarded. 


\section{Appendix References}

Higgins JP, Thompson SG. Quantifying heterogeneity in a meta-analysis. Statistics in Medicine 2002;21:1539-1558.

Ioannidis JP, Patsopoulos NA, Evangelou E. Uncertainty in heterogeneity estimates in meta-analyses. BMJ 2007;335:914-916.

Salanti G. Indirect and mixed-treatment comparison, network, or multiple-treatments meta-analysis: many names, many benefits, many concerns for the next generation evidence synthesis school. Research Synthesis Methods 2012;3:80-97.

Salanti G, Marinho V, Higgins JP. A case study of multiple-treatments meta-analysis demonstrates that covariates should be considered. Journal of Clinical Epidemiology 2009;62:857-64.

Higgins JP, Jackson D, Barrett JK, Lu G, Ades AE, White IR. Consistency and inconsistency in network metaanalysis: concepts and models for multi-arm studies. Research Synthesis Methods 2012;3:98-110.

Dias S, Welton NJ, Caldwell DM, Ades AE. Checking consistency in mixed treatment comparison metaanalysis. Statistics in Medicine 2010;29:932-944. 